\title{
Predicted Cellular Interactors of the Endogenous Retrovirus-K Integrase Enzyme
}

\author{
Ilena Benoit ${ }^{1,+}$, Signy Brownell ${ }^{1,+}$ and Renée N. Douville ${ }^{1,2, * \text { (D) }}$ \\ 1 Department of Biology, University of Winnipeg, 599 Portage Avenue, Winnipeg, MB R3B 2G3, Canada; \\ benoit-i@webmail.uwinnipeg.ca (I.B.); brownell-s@webmail.uwinnipeg.ca (S.B.) \\ 2 Department of Immunology, University of Manitoba, 750 McDermot Avenue, Winnipeg, MB R3E 0T5, Canada \\ * Correspondence: r.douville@uwinnipeg.ca \\ + These authors contributed equally to this work.
}

Citation: Benoit, I.; Brownell, S.; Douville, R.N. Predicted Cellular Interactors of the Endogenous Retrovirus-K Integrase Enzyme. Microorganisms 2021, 9, 1509. https://doi.org/10.3390/ microorganisms 9071509

Academic Editors: Martin S. Staege and Alexander Emmer

Received: 16 June 2021

Accepted: 9 July 2021

Published: 14 July 2021

Publisher's Note: MDPI stays neutral with regard to jurisdictional claims in published maps and institutional affiliations.

Copyright: () 2021 by the authors. Licensee MDPI, Basel, Switzerland. This article is an open access article distributed under the terms and conditions of the Creative Commons Attribution (CC BY) license (https:// creativecommons.org/licenses/by/ $4.0 /)$.

\begin{abstract}
Integrase (IN) enzymes are found in all retroviruses and are crucial in the retroviral integration process. Many studies have revealed how exogenous IN enzymes, such as the human immunodeficiency virus (HIV) IN, contribute to altered cellular function. However, the same consideration has not been given to viral IN originating from symbionts within our own DNA. Endogenous retrovirus-K (ERVK) is pathologically associated with neurological and inflammatory diseases along with several cancers. The ERVK IN interactome is unknown, and the question of how conserved the ERVK IN protein-protein interaction motifs are as compared to other retroviral integrases is addressed in this paper. The ERVK IN protein sequence was analyzed using the Eukaryotic Linear Motif (ELM) database, and the results are compared to ELMs of other betaretroviral INs and similar eukaryotic INs. A list of putative ERVK IN cellular protein interactors was curated from the ELM list and submitted for STRING analysis to generate an ERVK IN interactome. KEGG analysis was used to identify key pathways potentially influenced by ERVK IN. It was determined that the ERVK IN potentially interacts with cellular proteins involved in the DNA damage response (DDR), cell cycle, immunity, inflammation, cell signaling, selective autophagy, and intracellular trafficking. The most prominent pathway identified was viral carcinogenesis, in addition to select cancers, neurological diseases, and diabetic complications. This potentiates the role of ERVK IN in these pathologies via protein-protein interactions facilitating alterations in key disease pathways.
\end{abstract}

Keywords: endogenous retrovirus; integrase; interactome; eukaryotic linear motif; DNA damage response; viral carcinogenesis; cancer; amyotrophic lateral sclerosis; diabetes; model organisms

\section{Introduction}

Viral proteins often usurp and alter cellular signaling pathways. For exogenous viruses, this tweaking of cellular function serves to enhance their replicative success through the modulation of pathways related to virion production, dissemination, cell survival, and immunity [1,2]. It is less clear in what manner ever-present viral symbionts such as endogenous retroviruses (ERVs) interact with the proteome of their hosts.

The genomes of eukaryotic organisms are widely populated with ERVs [3-5]. Endogenous retrovirus-K (ERVK/HERV-K) is a biomedically-relevant symbiont within the primate lineage [6,7]. Its expression has been associated with a variety of cancers [8], neurological conditions [9-13], autoimmune diseases [14], and infections [13,15]. A common thread that weaves through ERVK-associated disease is genomic instability. DNA damage and genomic alterations are hallmarks of many cancers [16], as well as in the neurons of patients with the motor neuron disease ALS $[17,18]$. One protein known to cause DNA damage during the retroviral life cycle is the integrase (IN) enzyme [19]. Recovery from IN-driven lesions is reliant on the host DNA damage response (DDR) [20,21].

We have previously shown that several ERVK insertions in the human genome have the potential to produce functional ERVK IN enzymes with the identical DDE active 
site motif found in human immunodeficiency virus (HIV) IN [22]. Based on homology modeling, we predict that the ERVK IN enzyme contains all the essential motifs and domain structures for retroviral IN function [22]. A recombinant ERVK-10 integrase enzyme also confirms that it has the potential for strand-transfer activity [23]. A remaining question is how ERVK IN interacts with cellular proteins and pathways, as has been shown for many other retroviral integrases [19,24-26].

Retroviral INs are involved in pre-integration complex (PIC) transport [27], viral genome integration into host DNA [19], and virion maturation [28]. Thus, retroviral integrase enzymes exhibit a diversity of cellular partners and have been shown to impact cell signaling and survival processes, including the DDR [19,29]. For example, retroviral IN often recruits viral proteins (reverse transcriptase, matrix, and capsid) and cellular factors (BANF1, HGMA1, LEDGF) to participate in the viral DNA integration process [30,31]. Moreover, successful viral DNA integration requires engagement of the host DDR proteins to repair residual single-stranded DNA gaps flanking the integration site [20,29,32]. In contrast, failed provirus insertion or unresolved lesions can lead to double-stranded DNA (dsDNA) breaks in the host genome [29]. The level of $\gamma \mathrm{H} 2 \mathrm{AX}$ foci is positively correlated with the number of double-stranded DNA breaks (DSB) in mammalian cells, and it is widely used as a quantitative biomarker of retrovirus-mediated DSBs [19,33,34]. This genomic damage is particularly hazardous to the cell, as DSB potentially lead to chromosomal rearrangements, cellular deregulation, and apoptosis [35,36]. Thus, as an intrinsic protective measure, select host proteins (RAD51, Kap1, TREX1, p21, HDAC10, TRIM33) are known antagonists of the retroviral integration process [31,37-40]. Many studies have identified direct protein binding partners and cellular complexes which interact with HIV integrase [41-43]; in contrast, the ERVK IN interactome remains unknown.

A complicating factor for the development of model systems to study the impact of ERVK proteins in vivo is that many other organisms contain ERVs with similarity to ERVK. Given the known cellular impacts of retroviral integrases, we hypothesized that a computational biology approach would identify potential cellular partners of ERVK IN and point toward its capacity to modulate cellular pathways. Additionally, a comparison with similar integrases in eukaryotic organism and model species may inform the future establishment of in vivo models for ERVK IN-driven pathology.

\section{Materials and Methods}

\subsection{Database Curation}

Integrases with sequence similarity to ERVK IN (based on ERVK-10 [22]; P10266.2) were identified using the National Centre for Biotechnology's (NCBI) Protein-protein Basic Local Alignment Search Tool (BLASTp) within the non-redundant (nr), model organisms (mo), and transcriptome shotgun assembly proteins (tsa) databases [44]. Default algorithm parameters were used, with E-value cut-offs for each database as follows: $\mathrm{E}<3.0 \times 10^{-70}(\mathrm{nr}), \mathrm{E}<0.01$ (mo), $\mathrm{E}<2.0 \times 10^{-10}$ (tsa). Sequences were grouped based on phylogeny as informed by ICTV (International Committee on Taxonomy of Viruses; 2021, https:/ / talk.ictvonline.org / (accessed on 16 May 2021)) or OneZoom (OneZoom Tree of Life Explorer; version 3.4.1; Software for Technical Computation; United Kingdom, 2021, https: / / www.onezoom.org/ (accessed on 16 May 2021)) [45] and are listed in Tables A1-A4.

\subsection{Protein Alignments and Eukaryotic Linear Motif Annotation}

The ERVK IN protein sequence, as well as select representative integrases from exogenous Betaretroviruses (Figure 1) or endogenous retroviruses (Figure 2) were aligned using Geneious Prime (version 2021.0.3; Software for Technical Computation; San Diego, CA, USA; Auckland, New Zealand, 2021) software [46]. A global alignment with free end gaps using BLOSUM62 matrix was performed. Longer sequences were truncated to overlap with the ERVK IN reference sequence. Figures depict the sequence logo and integrase active 
sites, with HHCC and DDE regions highlighted based on Conserved Domains Database (CDD) annotation [47].

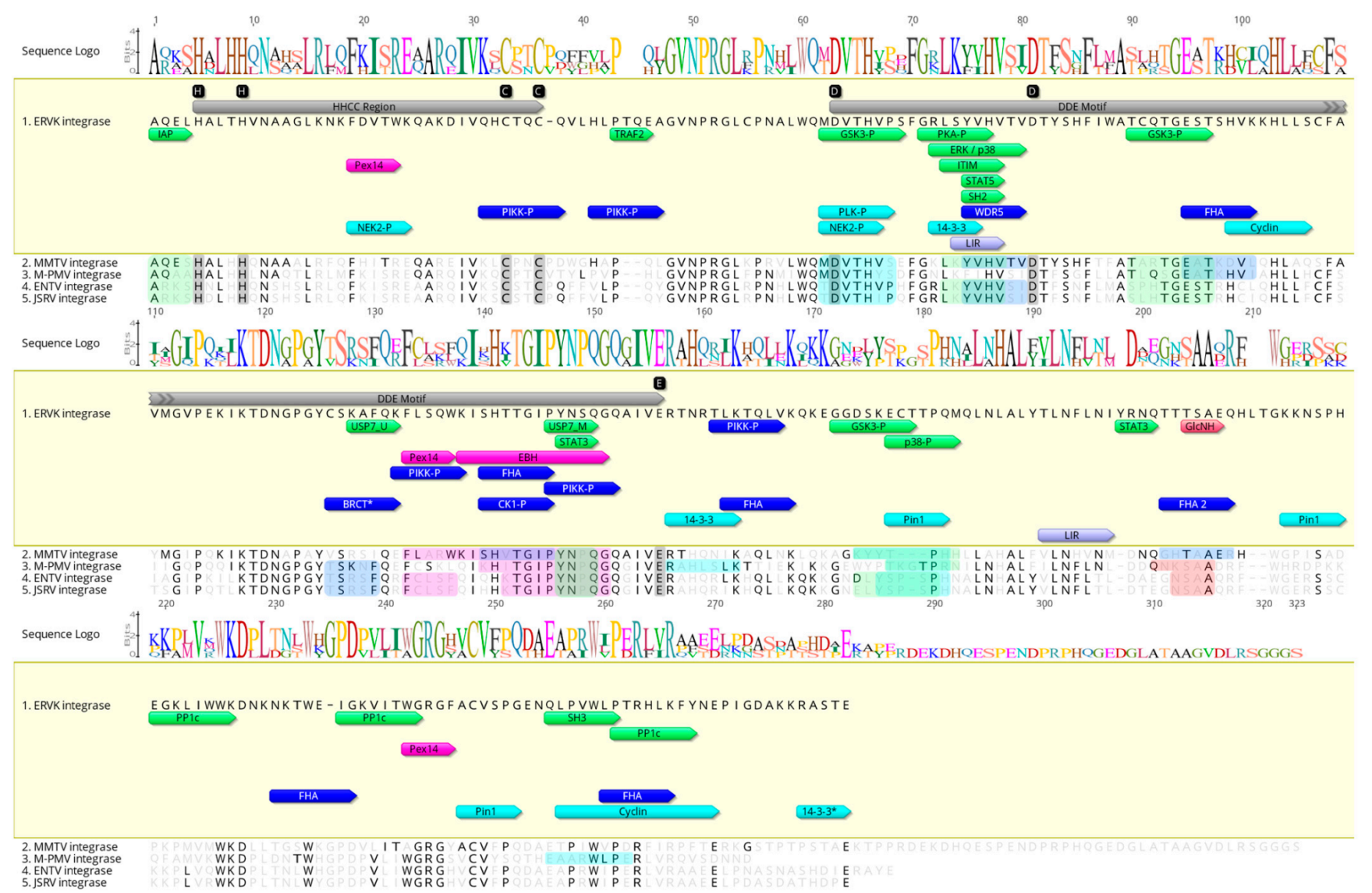

Figure 1. ERVK integrase and exogenous betaretrovirus integrases share common eukaryotic linear motifs. In silico examination of the conserved and differential eukaryotic linear motifs (ELMs) within Endogenous retrovirus-K (ERVK) and similar betaretroviral integrases. A betaretroviral integrase consensus sequence was constructed using GenBank sequences as follows: Endogenous retrovirus-K (ERVK; P10266.2), Exogenous mouse mammary tumor virus (MMTV; AAF31469.1), Mason-Pfizer monkey virus 5 (M-PMV; BBG56792.1), Enzootic nasal tumor virus (ENTV; ANG58699.1) and Jaagsiekte sheep retrovirus (JSRV; NP_041186.1). The HHCC region and DDE active site motif (gray, with key aa. in black) was positioned based on Conserved Domains annotations. ELMs were grouped based on related pathways: DNA damage response (dark blue), cell cycle (cyan), cell signaling (green), cell trafficking (magenta), autophagy (mauve), and glycosylation (red). ELM abbreviations used include: 14-3-3 = 14-3-3 protein interaction site, BRCT = BRCA1 C-terminus domain interaction site, CK1-P = casein kinase 1 phosphorylation site, Cyclin = cyclin docking site, EBH = end binding homology domain interaction site, ERK/p38 = ERK1/2 and p38 MAP kinase docking site, FHA = Forkhead-associated domain interaction site, GlyNH = glycosaminoglycan attachment site, GSK3-P = GSK3 phosphorylation site, IAP = inhibitor of apoptosis protein interaction site, ITIM = immunoreceptor tyrosine-based inhibitory motif, LIR = site that interacts with Atg8 protein family members, NEK2-P = NEK2 phosphorylation site, p38-P = p38 phosphorylation site, Pex14 = peroxisomal membrane docking via Pex14, PIKK-P = PIKK family phosphorylation site, Pin1 = docking site for Pin1 via WW domain interaction, PKA-P = PKA phosphorylation site, PLK-P = polo-like kinase phosphorylation site, $\mathrm{PP} 1 \mathrm{c}=$ protein phosphatase 1 catalytic subunit docking motif, $\mathrm{SH} 2$ = Src homology 2 domain interaction motif, SH3 = interaction site for non-canonical class I recognition specificity SH3 domains, STAT3 = STAT3 SH2 domain binding motif, STAT5 = STAT5 SH2 domain binding motif, TRAF2 = major TRAF2 binding consensus motif, USP7 = USP7 MATH (M) or UBL2 (U) domain interaction sites, WDR5 = interaction motif for WDR5 via WW domain interaction. Asterisks indicate ELMs unique to ERVK. Sequence alignment and annotation were performed using Geneious Prime software. 


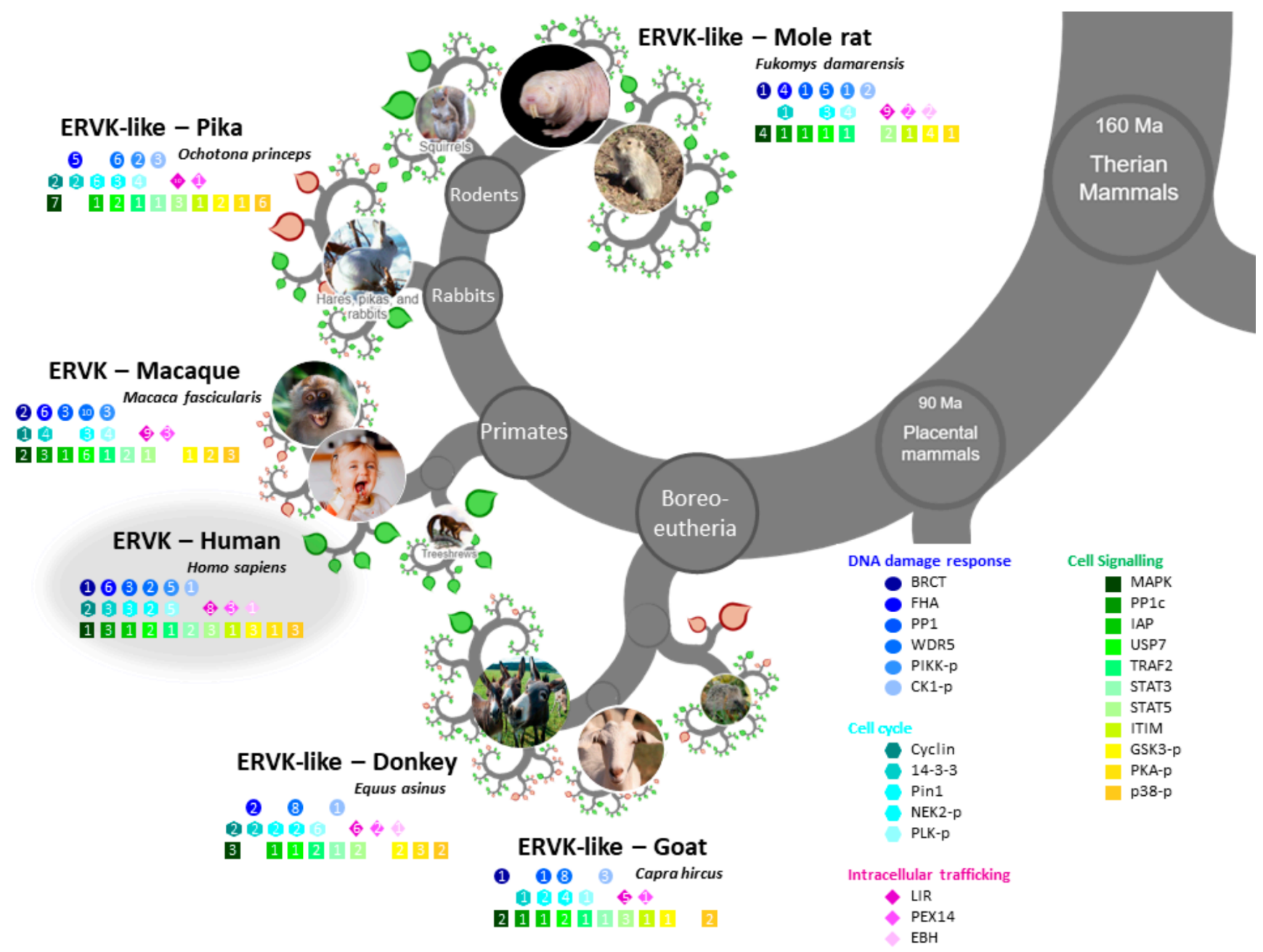

Figure 2. ERVK integrase and similar endogenous integrases share eukaryotic linear motifs patterns. Modified OneZoom image illustrating the conservation of ELM motifs in integrases from eukaryotic organisms (Homo sapiens, Macaca fasicicularis, Fukomys damarensis, Ochotona princeps, Equis asinus, and Capra hircus). Motifs are color-grouped according to function; DDR (blue), cell cycle (cyan), cell signaling (green), and intracellular trafficking (magenta). The number in each colored shape refers to the number of motifs with the respective integrase enzyme.

Each aligned integrase sequence was submitted to the Eukaryotic Linear Motif (ELM; Software for Technical Computation; 2020, http:/ / elm.eu.org / (accessed on 16 May 2021)) resource [48]. A complete listing of ELMs identified in each integrase is presented in Tables 1 and 2. ELMs unique to ERVK IN, as well as ELM sites exhibiting motif consensus above $70 \%$ with other integrases, were annotated in Figures 1 and 2.

\subsection{STRING Analysis and KEGG Pathways}

To identify potential ERVK IN binding partners based on ELM motifs, the names of interacting proteins were curated from each ELM reference page. When only a general interaction domain for a given ELM was listed, it was further linked to the InterPro database to curate a list of human proteins containing the interaction domain. Based on the 48 ELMs identified in ERVK IN, a total of 213 putative human protein interaction partners were identified (Table A5). The list was submitted to STRING (String Consortium; version 11.0; Software for Technical Computation; 2020, https: / / string-db.org/, accessed on 16 May 2021) for network analysis. Full network analysis was performed using Experiment and Databases as active interaction sources. Nodes indicate submitted query proteins only, with edges indicating confidence lines with a minimum interaction score of 0.9 (highest confidence). Query proteins unlinked to the network were excluded from analysis. A 
payload list was used to color hub proteins based on cellular function. KEGG pathways associated with the network analysis (E value $<1.0 \times 10^{-5}$ ) were presented in a heatmap using GraphPad Prism (version 9.1.1) software, and the full list of KEGG pathways is presented in Table A6.

Table 1. ELM motifs in integrases from ERVK and exogenous betaretroviruses.

\begin{tabular}{|c|c|c|c|c|c|c|c|c|c|}
\hline & \multirow[b]{2}{*}{ ELM Motif } & \multirow[b]{2}{*}{ ELM Accession } & \multirow[b]{2}{*}{ Alignment Notation } & \multicolumn{5}{|c|}{ Integrase } & \multirow{2}{*}{ 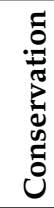 } \\
\hline & & & & $\underset{\underline{\pi}}{\stackrel{v}{z}}$ & $\sum_{\Sigma}^{Z}$ & $\frac{\sum}{\sum}$ & $\underset{z}{Z}$ & $\underset{\sim}{\stackrel{a}{a}}$ & \\
\hline \multirow{6}{*}{ 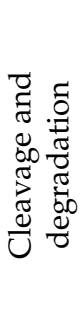 } & CLV_C14_Caspase3-7 & ELME000321 & & 1 & 0 & 0 & 0 & 2 & 0.4 \\
\hline & CLV_PCSK_KEX2_1 & ELME000108 & & 1 & 0 & 0 & 0 & 0 & 0.2 \\
\hline & CLV_NRD_NRD_1 & ELME000102 & & 0 & 1 & 0 & 1 & 1 & 0.6 \\
\hline & CLV_PCSK_PC1ET2_1 & ELME000100 & & 1 & 0 & 0 & 0 & 0 & 0.2 \\
\hline & CLV_PCSK_SKI1_1 & ELME000146 & & 5 & 4 & 4 & 1 & 0 & 0.8 \\
\hline & DEG_APCC_DBOX_1 & ELME000231 & & 0 & 0 & 0 & 1 & 0 & 0.2 \\
\hline \multirow{10}{*}{ 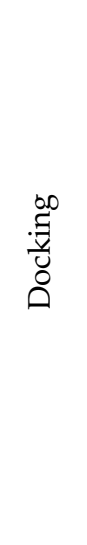 } & DOC_CKS1_1 & ELME000358 & & 0 & 1 & 0 & 0 & 0 & 0.2 \\
\hline & DOC_CYCLIN_RxL_1 & ELME000106 & Cyclin & 2 & 0 & 2 & 0 & 0 & 0.4 \\
\hline & DOC_MAPK_gen_1 & ELME000233 & & 0 & 2 & 0 & 1 & 1 & 0.6 \\
\hline & DOC_MAPK_MEF2A_6 & ELME000432 & $\mathrm{ERK} / \mathrm{p} 38$ & 1 & 1 & 0 & 1 & 1 & 0.8 \\
\hline & DOC_PP1_RVXF_1 & ELME000137 & PP1c & 3 & 1 & 1 & 1 & 1 & 1.0 \\
\hline & DOC_PP2B_LxvP_1 & ELME000367 & & 1 & 0 & 1 & 0 & 0 & 0.4 \\
\hline & DOC_PP4_FxxP_1 & ELME000477 & & 0 & 1 & 0 & 1 & 1 & 0.6 \\
\hline & DOC_USP7_MATH_1 & ELME000239 & USP7_M & 1 & 3 & 0 & 2 & 2 & 0.8 \\
\hline & DOC_USP7_UBL2_3 & ELME000394 & USP7_U & 1 & 0 & 1 & 0 & 0 & 0.4 \\
\hline & DOC_WW_Pin1_4 & ELME000136 & Pin1 & 3 & 6 & 1 & 3 & 2 & 1.0 \\
\hline \multirow{18}{*}{$\begin{array}{l}\widetilde{\varpi} \\
\widetilde{\Xi} \\
.00 \\
.7\end{array}$} & LIG_14-3-3_CanoR_1 & ELME000417 & $14-3-3$ & 2 & 1 & 1 & 2 & 2 & 1.0 \\
\hline & LIG_14-3-3_CterR_2 & ELME000418 & $14-3-3$ * & 1 & 0 & 0 & 0 & 0 & 0.2 \\
\hline & LIG_Actin_WH2_2 & ELME000313 & & 0 & 1 & 0 & 1 & 1 & 0.6 \\
\hline & LIG_APCC_ABBA_1 & ELME000435 & & 0 & 1 & 0 & 0 & 0 & 0.2 \\
\hline & LIG_BIR_II_1 & ELME000285 & IAP & 1 & 1 & 1 & 1 & 1 & 1.0 \\
\hline & LIG_BIR_III_4 & ELME000293 & & 0 & 0 & 0 & 1 & 0 & 0.2 \\
\hline & LIG_BRCT_BRCA1_1 & ELME000197 & $\mathrm{BRCT}$ & 1 & 0 & 1 & 1 & 1 & 0.8 \\
\hline & LIG_BRCT_BRCA1_2 & ELME000198 & BRCT1 * & 1 & 0 & 0 & 0 & 0 & 0.2 \\
\hline & LIG_CSL_BTD_1 & ELME000410 & & 1 & 1 & 0 & 0 & 0 & 0.4 \\
\hline & LIG_EH1_1 & ELME000148 & & 0 & 0 & 1 & 0 & 1 & 0.4 \\
\hline & LIG_eIF4E_1 & ELME000317 & & 0 & 1 & 0 & 0 & 0 & 0.2 \\
\hline & LIG_FHA_1 & ELME000052 & FHA & 5 & 1 & 2 & 0 & 1 & 0.8 \\
\hline & LIG_FHA_2 & ELME000220 & FHA 2 & 1 & 1 & 1 & 0 & 0 & 0.6 \\
\hline & LIG_LIR_Apic_2 & ELME000369 & & 0 & 3 & 2 & 1 & 1 & 0.8 \\
\hline & LIG_LIR_Gen_1 & ELME000368 & LIR & 2 & 0 & 0 & 0 & 0 & 0.2 \\
\hline & LIG_MAD2 & ELME000167 & & 0 & 0 & 0 & 1 & 0 & 0.2 \\
\hline & LIG_NRBOX & ELME000045 & & 0 & 0 & 0 & 1 & 0 & 0.2 \\
\hline & LIG_LIR_Nem_3 & ELME000370 & & 0 & 6 & 7 & 1 & 4 & 0.8 \\
\hline
\end{tabular}


Table 1. Cont.

\begin{tabular}{|c|c|c|c|c|c|c|c|c|c|}
\hline & \multirow[b]{2}{*}{ ELM Motif } & \multirow[b]{2}{*}{ ELM Accession } & \multirow[b]{2}{*}{ Alignment Notation } & \multicolumn{5}{|c|}{ Integrase } & \multirow{2}{*}{ 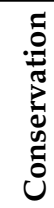 } \\
\hline & & & & $\underset{\frac{\pi}{\mid r}}{\stackrel{v}{a}}$ & $\sum$ & $\frac{\sum}{\sum}$ & $\underset{\mathbf{Z}}{\mathbf{Z}}$ & $\underset{\sim}{\stackrel{a}{a}}$ & \\
\hline & LIG_Pex14_1 & ELME000080 & Pex14 & 1 & 0 & 0 & 0 & 0 & 0.2 \\
\hline & LIG_Pex14_2 & ELME000328 & Pex14 & 2 & 2 & 1 & 1 & 1 & 1.0 \\
\hline & LIG_PTB_Apo_2 & ELME000122 & & 0 & 0 & 1 & 0 & 1 & 0.4 \\
\hline & LIG_PTB_Phospho_1 & ELME000095 & & 0 & 0 & 0 & 0 & 1 & 0.2 \\
\hline & LIG_RPA_C_Fungi & ELME000382 & & 0 & 0 & 1 & 1 & 1 & 0.6 \\
\hline & LIG_SH2_CRK & ELME000458 & & 0 & 2 & 0 & 0 & 0 & 0.2 \\
\hline & LIG_SH2_NCK_1 & ELME000474 & & 0 & 1 & 0 & 0 & 0 & 0.2 \\
\hline & LIG_SH2_PTP2 & ELME000083 & $\mathrm{SH} 2$ & 1 & 1 & 0 & 1 & 1 & 0.8 \\
\hline & LIG_SH2_SRC & ELME000081 & $\mathrm{SH} 2$ & 1 & 1 & 1 & 1 & 1 & 1.0 \\
\hline & LIG_SH2_STAP1 & ELME000465 & & 2 & 1 & 0 & 0 & 0 & 0.4 \\
\hline & LIG_SH2_STAT3 & ELME000163 & STAT3 & 2 & 1 & 1 & 1 & 1 & 1.0 \\
\hline & LIG_SH2_STAT5 & ELME000182 & STAT5 & 3 & 3 & 2 & 3 & 3 & 1.0 \\
\hline & LIG_SH3_1 & ELME000005 & & 0 & 1 & 0 & 0 & 0 & 0.2 \\
\hline & LIG_SH3_3 & ELME000155 & SH3 & 1 & 2 & 1 & 1 & 1 & 1.0 \\
\hline & LIG_SH3_4 & ELME000156 & & 0 & 0 & 0 & 1 & 0 & 0.2 \\
\hline & LIG_SxIP_EBH_1 & ELME000254 & EBH & 1 & 1 & 1 & 1 & 2 & 1.0 \\
\hline & LIG_TRAF2_1 & ELME000117 & TRAF2 & 1 & 1 & 0 & 1 & 1 & 0.8 \\
\hline & LIG_TYR_ITIM & ELME000020 & ITIM & 1 & 1 & 1 & 1 & 1 & 1.0 \\
\hline & LIG_Vh1_VBS_1 & ELME000438 & & 0 & 0 & 0 & 0 & 1 & 0.2 \\
\hline & LIG_WD40_WDR5_VDV_2 & ELME000365 & WDR5 & 2 & 10 & 3 & 8 & 9 & 1.0 \\
\hline & LIG_WW_3 & ELME000135 & & 0 & 1 & 0 & 0 & 0 & 0.2 \\
\hline \multirow{17}{*}{ 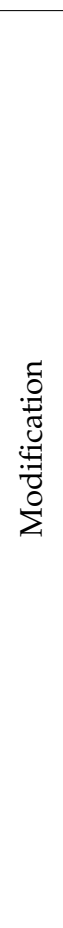 } & MOD_CDK_SPK_2 & ELME000429 & & 0 & 0 & 1 & 0 & 0 & 0.2 \\
\hline & MOD_CDK_SPxK_1 & ELME000153 & & 0 & 1 & 0 & 0 & 0 & 0.2 \\
\hline & MOD_CK1_1 & ELME000063 & CK1-P & 1 & 3 & 2 & 4 & 4 & 1.0 \\
\hline & MOD_CK2_1 & ELME000064 & & 3 & 3 & 1 & 0 & 0 & 0.6 \\
\hline & MOD_Cter_Amidation & ELME000093 & & 1 & 0 & 0 & 0 & 0 & 0.2 \\
\hline & MOD_GlcNHglycan & ELME000085 & GlyNH & 1 & 2 & 3 & 1 & 2 & 1.0 \\
\hline & MOD_GSK3_1 & ELME000053 & GSK3-P & 3 & 4 & 2 & 1 & 2 & 1.0 \\
\hline & MOD_NEK2_1 & ELME000336 & NEK2-P & 2 & 3 & 3 & 2 & 4 & 1.0 \\
\hline & MOD_NEK2_2 & ELME000337 & & 0 & 0 & 1 & 0 & 0 & 0.2 \\
\hline & MOD_N-GLC_1 & ELME000070 & & 1 & 0 & 1 & 2 & 0 & 0.6 \\
\hline & MOD_PIKK_1 & ELME000202 & & 5 & 0 & 1 & 0 & 0 & 0.4 \\
\hline & MOD_PKA_1 & ELME000008 & & 0 & 1 & 0 & 0 & 0 & 0.2 \\
\hline & MOD_PKA_2 & ELME000062 & PKA-P & 1 & 0 & 1 & 2 & 2 & 0.8 \\
\hline & MOD_Plk_1 & ELME000442 & PLK-P & 4 & 1 & 2 & 1 & 1 & 1.0 \\
\hline & MOD_Plk_4 & ELME000444 & & 1 & 0 & 1 & 0 & 0 & 0.4 \\
\hline & MOD_ProDKin_1 & ELME000159 & p38-P & 3 & 6 & 1 & 3 & 2 & 1.0 \\
\hline & MOD_SUMO_rev_2 & ELME000393 & & 1 & 1 & 0 & 0 & 0 & 0.4 \\
\hline
\end{tabular}


Table 1. Cont.

\begin{tabular}{|c|c|c|c|c|c|c|c|c|c|}
\hline & \multirow[b]{2}{*}{ ELM Motif } & \multirow[b]{2}{*}{ ELM Accession } & \multirow[b]{2}{*}{ Alignment Notation } & \multicolumn{5}{|c|}{ Integrase } & \multirow{2}{*}{ 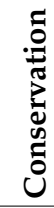 } \\
\hline & & & & 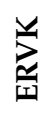 & $\sum_{\Sigma}^{B}$ & $\frac{\sum_{i}}{\sum}$ & $\underset{z}{z}$ & $\underset{\sim}{\stackrel{\Xi}{a}}$ & \\
\hline \multirow{2}{*}{ 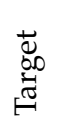 } & TRG_ENDOCYTIC_2 & ELME000120 & & 2 & 4 & 2 & 1 & 1 & 1.0 \\
\hline & $\begin{array}{c}\text { TRG_Pf- } \\
\text { PMV_PEXEL_1 }\end{array}$ & ELME000462 & & 1 & 2 & 1 & 1 & 1 & 1.0 \\
\hline
\end{tabular}

GenBank accession numbers for betaretroviral integrase sequences are as follows: Endogenous retrovirus-K (ERVK; P10266.2), Exogenous mouse mammary tumor virus (MMTV; AAF31469.1), Mason-Pzifer monkey virus 5 (M-PMV; BBG56792.1), Enzootic nasal tumor virus (ENTV; ANG58699.1) and Jaagsiekte sheep retrovirus (JSRV; NP_041186.1). Asterisk indicates ERVK-specific ELM motif in Figure 1.

Table 2. ELM motifs in ERVK integrase and similar endogenous integrases in eukaryotes.

\begin{tabular}{|c|c|c|c|c|c|c|c|c|c|c|c|c|c|c|}
\hline & ELM Motif & ELM Accession & 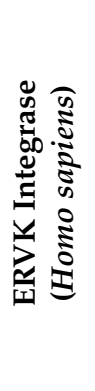 & 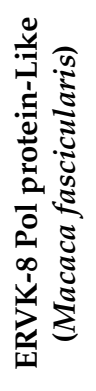 & 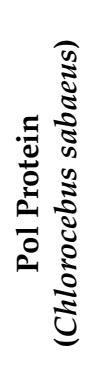 & 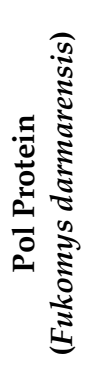 & 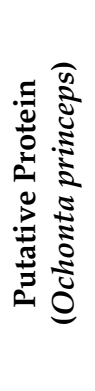 & 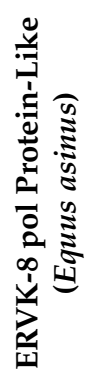 & 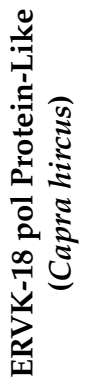 & 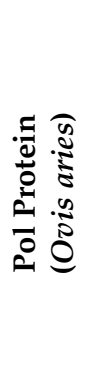 & 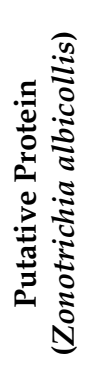 & 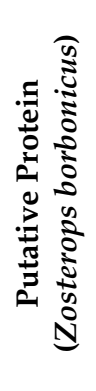 & 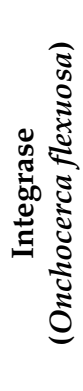 & 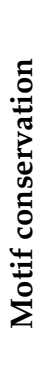 \\
\hline \multirow{5}{*}{ 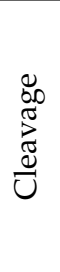 } & CLV_C14_Caspase3-7 & ELME000321 & 1 & 0 & 0 & 0 & 1 & 0 & 0 & 0 & 0 & 0 & 0 & 0.2 \\
\hline & CLV_NRD_NRD_1 & ELME000102 & 0 & 0 & 0 & 0 & 0 & 0 & 0 & 1 & 0 & 0 & 1 & 0.2 \\
\hline & CLV_PCSK_KEX2_1 & ELME000108 & 1 & 2 & 0 & 0 & 0 & 0 & 0 & 0 & 0 & 1 & 0 & 0.3 \\
\hline & CLV_PCSK_PC1ET2_1 & ELME000100 & 1 & 2 & 0 & 0 & 0 & 0 & 0 & 0 & 0 & 1 & 0 & 0.3 \\
\hline & CLV_PCSK_SKI1_1 & ELME000146 & 5 & 3 & 4 & 3 & 7 & 8 & 0 & 0 & 3 & 5 & 2 & 0.8 \\
\hline \multirow{2}{*}{ 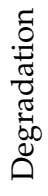 } & DEG_APCC_DBOX_1 & ELME000231 & 0 & 0 & 0 & 0 & 0 & 0 & 0 & 0 & 0 & 0 & 1 & 0.1 \\
\hline & DEG_MDM2_SWIB_1 & ELME000184 & 0 & 0 & 0 & 0 & 0 & 0 & 0 & 0 & 1 & 0 & 0 & 0.1 \\
\hline \multirow{15}{*}{ 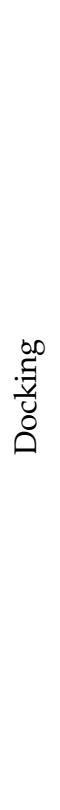 } & DOC_CKS1_1 & ELME000358 & 0 & 1 & 0 & 0 & 2 & 0 & 0 & 0 & 1 & 2 & 1 & 0.5 \\
\hline & DOC_CYCLIN_RxL_1 & ELME000106 & 2 & 1 & 2 & 0 & 2 & 2 & 0 & 0 & 3 & 3 & 1 & 0.7 \\
\hline & DOC_MAPK_DCC_7 & ELME000433 & 0 & 0 & 0 & 1 & 0 & 0 & 0 & 0 & 0 & 0 & 1 & 0.2 \\
\hline & DOC_MAPK_gen_1 & ELME000233 & 0 & 1 & 0 & 3 & 5 & 2 & 1 & 1 & 2 & 4 & 1 & 0.8 \\
\hline & DOC_MAPK_HePTP_8 & ELME000434 & 0 & 0 & 0 & 0 & 0 & 0 & 0 & 0 & 0 & 0 & 1 & 0.1 \\
\hline & DOC_MAPK_MEF2A_6 & ELME000432 & 1 & 1 & 0 & 0 & 2 & 1 & 1 & 1 & 3 & 4 & 3 & 0.8 \\
\hline & DOC_PP1_RVXF_1 & ELME000137 & 3 & 3 & 1 & 1 & 0 & 0 & 1 & 1 & 0 & 1 & 1 & 0.7 \\
\hline & DOC_PP2A_B56_1 & ELME000425 & 0 & 0 & 0 & 1 & 0 & 0 & 0 & 0 & 0 & 0 & 0 & 0.1 \\
\hline & DOC_PP2B_LxvP_1 & ELME000367 & 1 & 1 & 2 & 0 & 0 & 0 & 0 & 0 & 1 & 1 & 1 & 0.5 \\
\hline & DOC_PP2B_PxIxI_1 & ELME000237 & 0 & 0 & 0 & 0 & 1 & 0 & 0 & 0 & 0 & 0 & 0 & 0.1 \\
\hline & DOC_PP4_FxxP_1 & ELME000477 & 0 & 1 & 1 & 1 & 1 & 1 & 1 & 0 & 0 & 0 & 2 & 0.6 \\
\hline & DOC_USP7_MATH_1 & ELME000239 & 1 & 3 & 0 & 1 & 1 & 1 & 2 & 2 & 3 & 1 & 3 & 0.9 \\
\hline & DOC_USP7_MATH_2 & ELME000240 & 0 & 1 & 0 & 0 & 1 & 0 & 0 & 0 & 0 & 0 & 0 & 0.2 \\
\hline & DOC_USP7_UBL2_3 & ELME000394 & 1 & 2 & 0 & 0 & 0 & 0 & 0 & 0 & 1 & 3 & 0 & 0.4 \\
\hline & DOC_WW_Pin1_4 & ELME000136 & 3 & 0 & 1 & 0 & 6 & 2 & 2 & 2 & 3 & 3 & 1 & 0.8 \\
\hline
\end{tabular}


Table 2. Cont.

\begin{tabular}{|c|c|c|c|c|c|c|c|c|c|c|c|c|c|c|}
\hline & ELM Motif & ELM Accession & 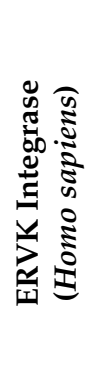 & 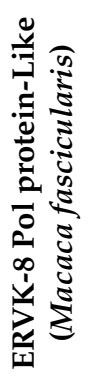 & 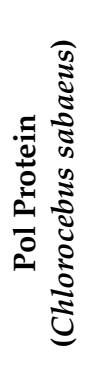 & 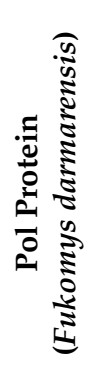 & 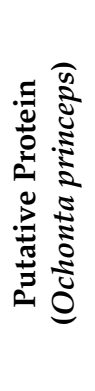 & 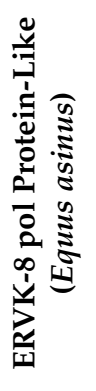 & 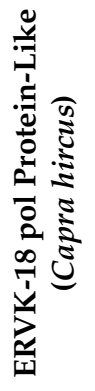 & 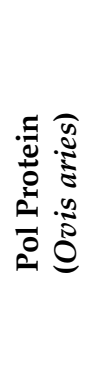 & 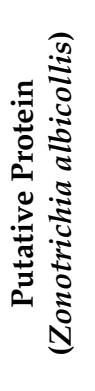 & 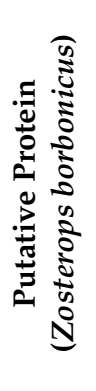 & 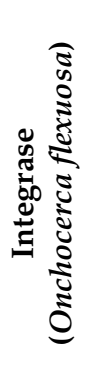 & 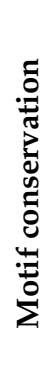 \\
\hline \multirow{34}{*}{$\begin{array}{l}\overparen{\varpi} \\
\underset{ే}{ే} \\
.00 \\
.]\end{array}$} & LIG_14-3-3_CanoR_1 & ELME000417 & 2 & 4 & 1 & 1 & 2 & 2 & 1 & 2 & 3 & 1 & 1 & 1.0 \\
\hline & LIG_14-3-3_CterR_2 & ELME000418 & 1 & 0 & 0 & 0 & 0 & 0 & 0 & 0 & 0 & 0 & 0 & 0.1 \\
\hline & LIG_Actin_WH2_2 & ELME000313 & 0 & 0 & 1 & 1 & 0 & 0 & 1 & 1 & 0 & 1 & 1 & 0.5 \\
\hline & LIG_APCC_ABBA_1 & ELME000435 & 0 & 0 & 0 & 1 & 0 & 1 & 0 & 0 & 0 & 0 & 0 & 0.2 \\
\hline & LIG_BIR_II_1 & ELME000285 & 1 & 1 & 1 & 1 & 1 & 1 & 1 & 1 & 1 & 1 & 1 & 1.0 \\
\hline & LIG_BIR_III_4 & ELME000293 & 0 & 0 & 0 & 0 & 0 & 0 & 1 & 1 & 0 & 0 & 0 & 0.2 \\
\hline & LIG_BRCT_BRCA1_1 & ELME000197 & 1 & 2 & 0 & 1 & 0 & 0 & 1 & 1 & 0 & 0 & 2 & 0.5 \\
\hline & LIG_BRCT_BRCA1_2 & ELME000198 & 1 & 1 & 0 & 0 & 0 & 0 & 0 & 0 & 0 & 0 & 0 & 0.2 \\
\hline & LIG_CSL_BTD_1 & ELME000410 & 1 & 0 & 1 & 1 & 1 & 1 & 0 & 0 & 0 & 0 & 0 & 0.5 \\
\hline & LIG_deltaCOP1_diTrp_1 & ELME000459 & 0 & 0 & 0 & 0 & 0 & 0 & 0 & 0 & 1 & 0 & 0 & 0.1 \\
\hline & LIG_EH1_1 & ELME000148 & 0 & 0 & 1 & 0 & 0 & 0 & 1 & 1 & 0 & 0 & 0 & 0.3 \\
\hline & LIG_eIF4E_1 & ELME000317 & 0 & 0 & 0 & 0 & 1 & 0 & 0 & 0 & 0 & 0 & 1 & 0.2 \\
\hline & LIG_FHA_1 & ELME000052 & 5 & 5 & 5 & 3 & 2 & 0 & 0 & 1 & 1 & 1 & 4 & 0.8 \\
\hline & LIG_FHA_2 & ELME000220 & 1 & 1 & 0 & 1 & 3 & 2 & 0 & 0 & 0 & 1 & 0 & 0.5 \\
\hline & LIG_LIR_Apic_2 & ELME000369 & 0 & 3 & 3 & 2 & 1 & 2 & 1 & 1 & 1 & 0 & 1 & 0.8 \\
\hline & LIG_LIR_Gen_1 & ELME000368 & 2 & 1 & 1 & 1 & 2 & 1 & 0 & 1 & 1 & 1 & 0 & 0.8 \\
\hline & LIG_LIR_Nem_3 & ELME000370 & 6 & 5 & 7 & 6 & 7 & 3 & 4 & 4 & 1 & 3 & 6 & 1.0 \\
\hline & LIG_LYPXL_S_1 & ELME000294 & 0 & 0 & 0 & 0 & 0 & 0 & 0 & 0 & 0 & 0 & 1 & 0.1 \\
\hline & LIG_PCNA_PIPBox_1 & ELME000140 & 0 & 0 & 1 & 0 & 0 & 0 & 0 & 0 & 0 & 0 & 0 & 0.1 \\
\hline & LIG_PCNA_yPIPBox_3 & ELME000482 & 0 & 0 & 0 & 2 & 2 & 2 & 0 & 0 & 0 & 0 & 0 & 0.3 \\
\hline & LIG_Pex14_1 & ELME000080 & 1 & 0 & 0 & 0 & 1 & 0 & 0 & 0 & 2 & 2 & 0 & 0.4 \\
\hline & LIG_Pex14_2 & ELME000328 & 2 & 3 & 1 & 2 & 0 & 2 & 1 & 1 & 1 & 2 & 1 & 0.9 \\
\hline & LIG_PTB_Apo_2 & ELME000122 & 0 & 0 & 0 & 2 & 1 & 0 & 1 & 1 & 1 & 1 & 0 & 0.5 \\
\hline & LIG_PTB_Phospho_1 & ELME000095 & 0 & 0 & 0 & 1 & 1 & 0 & 1 & 1 & 0 & 0 & 0 & 0.4 \\
\hline & LIG_REV1ctd_RIR_1 & ELME000450 & 0 & 0 & 0 & 0 & 0 & 0 & 0 & 0 & 1 & 0 & 0 & 0.1 \\
\hline & LIG_RPA_C_Fungi & ELME000382 & 0 & 0 & 0 & 0 & 0 & 0 & 1 & 1 & 0 & 1 & 0 & 0.3 \\
\hline & LIG_SH2_CRK & ELME000458 & 0 & 1 & 0 & 1 & 2 & 2 & 0 & 0 & 1 & 1 & 0 & 0.5 \\
\hline & LIG_SH2_GRB2like & ELME000084 & 0 & 0 & 0 & 0 & 0 & 0 & 0 & 0 & 0 & 0 & 1 & 0.1 \\
\hline & LIG_SH2_NCK_1 & ELME000474 & 0 & 1 & 0 & 1 & 0 & 1 & 0 & 0 & 1 & 1 & 0 & 0.5 \\
\hline & LIG_SH2_PTP2 & ELME000083 & 1 & 0 & 1 & 1 & 1 & 0 & 1 & 1 & 1 & 0 & 1 & 0.7 \\
\hline & LIG_SH2_SRC & ELME000081 & 1 & 0 & 2 & 1 & 1 & 1 & 1 & 1 & 1 & 0 & 2 & 0.8 \\
\hline & LIG_SH2_STAP1 & ELME000465 & 2 & 1 & 0 & 0 & 1 & 1 & 0 & 0 & 1 & 1 & 1 & 0.6 \\
\hline & LIG_SH2_STAT3 & ELME000163 & 2 & 2 & 1 & 0 & 1 & 1 & 1 & 1 & 0 & 0 & 1 & 0.7 \\
\hline & LIG_SH2_STAT5 & ELME000182 & 3 & 1 & 3 & 2 & 3 & 2 & 3 & 3 & 3 & 2 & 5 & 1.0 \\
\hline
\end{tabular}


Table 2. Cont.

\begin{tabular}{|c|c|c|c|c|c|c|c|c|c|c|c|c|c|c|}
\hline & ELM Motif & ELM Accession & 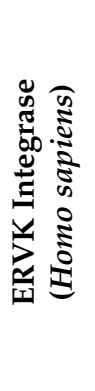 & 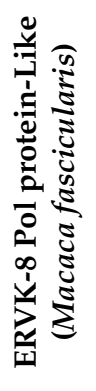 & 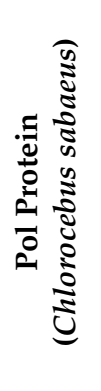 & 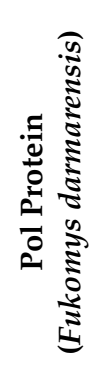 & 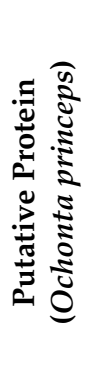 & 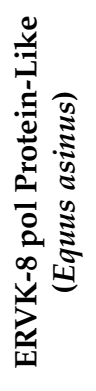 & 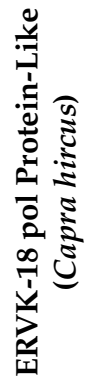 & 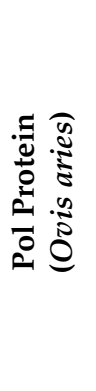 & 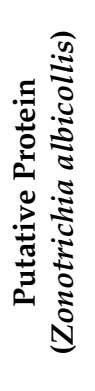 & 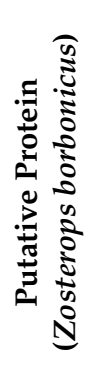 & 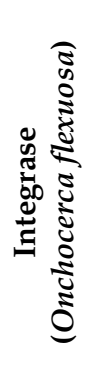 & 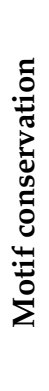 \\
\hline & LIG_SH3_3 & ELME000155 & 1 & 2 & 1 & 1 & 3 & 2 & 1 & 1 & 5 & 4 & 2 & 1.0 \\
\hline & LIG_SUMO_SIM_par_1 & ELME000333 & 0 & 1 & 0 & 1 & 0 & 0 & 0 & 0 & 1 & 2 & 0 & 0.4 \\
\hline & LIG_SxIP_EBH_1 & ELME000254 & 1 & 0 & 1 & 2 & 0 & 1 & 0 & 2 & 0 & 1 & 1 & 0.6 \\
\hline & LIG_TRAF2_1 & ELME000117 & 1 & 1 & 0 & 1 & 1 & 2 & 1 & 1 & 0 & 0 & 0 & 0.6 \\
\hline & LIG_TRAF6 & ELME000133 & 0 & 0 & 0 & 0 & 0 & 1 & 0 & 0 & 0 & 0 & 0 & 0.1 \\
\hline & LIG_TRFH_1 & ELME000249 & 0 & 0 & 0 & 0 & 0 & 0 & 0 & 0 & 0 & 0 & 1 & 0.1 \\
\hline & LIG_TYR_ITIM & ELME000020 & 1 & 0 & 2 & 1 & 1 & 0 & 1 & 1 & 1 & 0 & 1 & 0.7 \\
\hline & LIG_UBA3_1 & ELME000395 & 0 & 0 & 1 & 0 & 0 & 0 & 0 & 0 & 0 & 0 & 1 & 0.2 \\
\hline & LIG_Vh1_VBS_1 & ELME000438 & 0 & 0 & 0 & 1 & 0 & 0 & 1 & 1 & 0 & 1 & 0 & 0.4 \\
\hline & LIG_WD40_WDR5_VDV & _1ELME000364 & 0 & 0 & 0 & 0 & 0 & 0 & 0 & 0 & 0 & 1 & 0 & 0.1 \\
\hline & LIG_WD40_WDR5_VDV & 2ELME000365 & 2 & 10 & 6 & 5 & 6 & 8 & 8 & 8 & 10 & 10 & 12 & 1.0 \\
\hline & LIG_WW_3 & ELME000135 & 0 & 0 & 0 & 1 & 0 & 0 & 0 & 0 & 0 & 0 & 0 & 0.1 \\
\hline \multirow{21}{*}{ 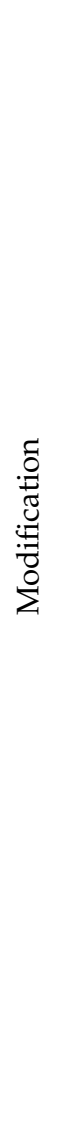 } & MOD_CDK_SPK_2 & ELME000429 & 0 & 0 & 1 & 0 & 1 & 0 & 0 & 0 & 0 & 0 & 1 & 0.3 \\
\hline & MOD_CDK_SPxxK_3 & ELME000428 & 0 & 0 & 0 & 0 & 1 & 1 & 0 & 0 & 1 & 1 & 0 & 0.4 \\
\hline & MOD_CK1_1 & ELME000063 & 1 & 0 & 1 & 2 & 3 & 1 & 3 & 3 & 4 & 3 & 3 & 0.9 \\
\hline & MOD_CK2_1 & ELME000064 & 3 & 2 & 1 & 4 & 3 & 2 & 0 & 0 & 0 & 1 & 0 & 0.6 \\
\hline & MOD_CMANNOS & ELME000160 & 0 & 0 & 0 & 0 & 1 & 0 & 0 & 0 & 0 & 0 & 0 & 0.1 \\
\hline & MOD_Cter_Amidation & ELME000093 & 1 & 1 & 0 & 0 & 0 & 0 & 0 & 0 & 0 & 0 & 0 & 0.2 \\
\hline & MOD_GlcNHglycan & ELME000085 & 1 & 3 & 3 & 3 & 2 & 0 & 2 & 2 & 4 & 2 & 5 & 0.9 \\
\hline & MOD_GSK3_1 & ELME000053 & 3 & 1 & 3 & 4 & 2 & 2 & 1 & 1 & 0 & 4 & 6 & 0.9 \\
\hline & MOD_NEK2_1 & ELME000336 & 2 & 3 & 3 & 2 & 2 & 1 & 4 & 4 & 1 & 2 & 3 & 1.0 \\
\hline & MOD_NEK2_2 & ELME000337 & 0 & 0 & 1 & 1 & 1 & 1 & 0 & 0 & 1 & 0 & 1 & 0.5 \\
\hline & MOD_N-GLC_1 & ELME000070 & 3 & 0 & 0 & 2 & 1 & 1 & 0 & 0 & 2 & 1 & 1 & 0.6 \\
\hline & MOD_N-GLC_2 & ELME000079 & 0 & 0 & 1 & 0 & 2 & 0 & 0 & 0 & 0 & 0 & 1 & 0.3 \\
\hline & MOD_PIKK_1 & ELME000202 & 5 & 3 & 2 & 1 & 2 & 0 & 0 & 0 & 2 & 1 & 0 & 0.6 \\
\hline & MOD_PK_1 & ELME000065 & 0 & 2 & 0 & 0 & 0 & 1 & 0 & 0 & 0 & 0 & 1 & 0.3 \\
\hline & MOD_PKA_1 & ELME000008 & 0 & 1 & 0 & 1 & 0 & 1 & 0 & 0 & 0 & 1 & 0 & 0.4 \\
\hline & MOD_PKA_2 & ELME000062 & 1 & 1 & 1 & 1 & 1 & 2 & 0 & 2 & 1 & 0 & 2 & 0.8 \\
\hline & MOD_Plk_1 & ELME000442 & 4 & 2 & 1 & 2 & 2 & 4 & 1 & 1 & 2 & 3 & 2 & 1.0 \\
\hline & MOD_Plk_4 & ELME000444 & 1 & 2 & 3 & 2 & 2 & 2 & 0 & 0 & 1 & 2 & 0 & 0.7 \\
\hline & MOD_ProDKin_1 & ELME000159 & 3 & 3 & 1 & 0 & 6 & 2 & 2 & 2 & 3 & 3 & 1 & 0.9 \\
\hline & MOD_SUMO_for_1 & ELME000002 & 0 & 0 & 0 & 0 & 0 & 0 & 0 & 0 & 2 & 0 & 0 & 0.1 \\
\hline & MOD_SUMO_rev_2 & ELME000393 & 1 & 1 & 0 & 0 & 0 & 0 & 0 & 0 & 0 & 0 & 0 & 0.2 \\
\hline
\end{tabular}


Table 2. Cont.

\begin{tabular}{|c|c|c|c|c|c|c|c|c|c|c|c|c|c|c|}
\hline & ELM Motif & ELM Accession & 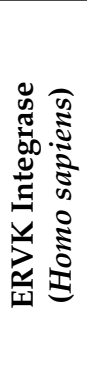 & 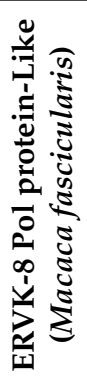 & 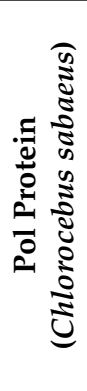 & 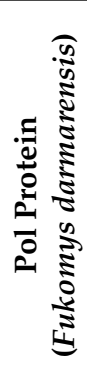 & 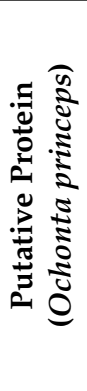 & 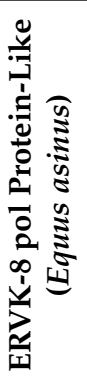 & 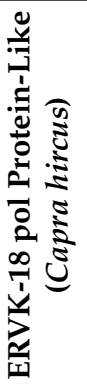 & 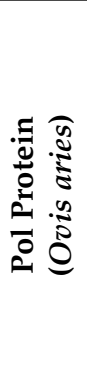 & 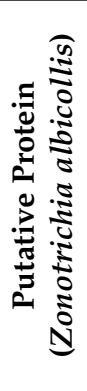 & 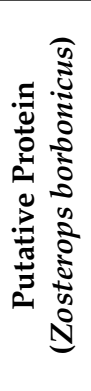 & 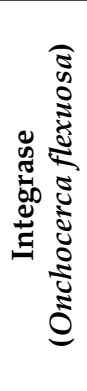 & 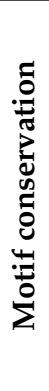 \\
\hline \multirow{4}{*}{ 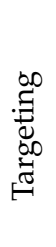 } & TRG_ENDOCYTIC_2 & ELME000120 & 2 & 1 & 3 & 2 & 2 & 2 & 1 & 1 & 2 & 1 & 2 & 1.0 \\
\hline & TRG_LysEnd_APsAcLL_1 & ELME000149 & 0 & 0 & 0 & 0 & 0 & 0 & 0 & 0 & 1 & 0 & 1 & 0.2 \\
\hline & TRG_NLS_MonoExtC_3 & ELME000278 & 0 & 0 & 0 & 0 & 0 & 1 & 0 & 0 & 0 & 0 & 0 & 0.1 \\
\hline & $\begin{array}{c}\text { TRG_Pf- } \\
\text { PMV_PEXEL_1 }\end{array}$ & ELME000462 & 1 & 1 & 1 & 1 & 1 & 1 & 1 & 1 & 1 & 1 & 1 & 1.0 \\
\hline
\end{tabular}

GenBank accession numbers for endogenous integrase sequences are as follows: Endogenous retrovirus-K (ERVK in Homo sapiens; P10266.2), ERVK-8 pol protein-like (Macaca fascicularis; XP_015309771.1), Pol protein (Chlorocebus sabaeus; KFO35018.1), Pol protein (Fukomys darmarensis; BBC20786.1), Putative protein (Ochonta princeps; XP_012786727.1), ERVK-8 pol protein-like (Equus asinus; XP_014715024.1), ERVK-18 pol protein-like (Capra hircus; XP_017905435.1), Pol protein (Ovis aries; ABV71120.1), Putative protein (Zonotrichia albicollis; TRZ15504.1), Putative protein (Zosterops borbonicus; XP_014125095.1), Integrase (Onchocerca flexuosa; OZC05619.1).

\section{Results \\ 3.1. Characterization of Eukaryotic Linear Motifs in ERVK Integrase and Other Betaretroviral Integrases}

To establish which exogenous and endogenous retroviruses contain integrase sequences most similar to ERVK IN, we performed BLASTp searches using the nr, mo, and tsa NCIB databases. As expected, exogenous Betaretroviruses were identified through BLASPp search, which included multiple hits for Mouse mammary tumor virus (MMTV), Mason-Pfizer monkey virus (M-PMV), Enzootic Nasal Tumor Virus (ENTV), and Jaagsiekte sheep retrovirus (JSRV) (Table A1).

Eukaryotic linear motif (ELM) analysis of a representative sequence from each genus was compared with ERVK IN and revealed the conservation of select protein motifs (Table 1, Figure 1). Apart from the conservation of the HHCC region and DDE active site motif, all betaretroviral integrases also contained many interaction motifs related to DRR, including Pin1 via [ST]P WW domain interaction motifs [49], PP1c docking motif for target dephosphorylation [50], and a S-X-X-S/T CK1 phosphorylation site [51]. All INs except for MMTV contained a low-affinity BRCA1 carboxy-terminal BRCT domain binding motif (CSKAF, aa. 126-132). Betaretroviral INs were also predicted to be phosphorylated by the cell cycle checkpoint kinases NEK2 [52] and PLK-1 [53], as well as interact with a canonical argininecontaining phospho-motif within cell cycle regulating 14-3-3 proteins [54]. Numerous cell signaling protein interactions were predicted including YXXQ motifs for the SH2 domain binding of STAT3 [55], additional SH2 binding motifs related to STAT5 [56] and SRC family kinases [57], SH3 binding motifs with non-canonical class I recognition specificity [58], an IAP-binding motif (aa. 1-4) for interaction with inhibitor of apoptosis proteins (IAP) [59], an ITIM motif [60], several GSK3 phosphorylation sites [61], and proline-directed ERK/p38 MAPK phosphorylation sites [62]. In addition, most betaretroviral IN enzymes contained features related to protein trafficking, such as a Wxxx[FY] motif (aa. 133-137 in ERVK, MMTV, ENTV, and JRSV) that binds Pex13 and Pex14 for peroxisomal import [63], a SxIP motif (aa. 137-150) that binds to EBH domains in end-binding proteins involved in microtubule transport [64], and a tyrosine-based YXXØ sorting signal (aa. 75-78) for interaction with the $\mu$-subunit of adaptor protein complex [65] and a PEXEL-like motif [66]. The DDE region displayed the most consistent pattern of conserved ELMs among the betaretroviral INs. It is important to note that despite the similar complement of ELM 
motifs in betaretroviral integrases, many were positioned at sites differently than in ERVK IN. Additional ELMs and their motif frequencies in individual betaretroviral integrases are listed in Table 1.

\subsection{Characterization of Eukaryotic Linear Motifs in ERVK Integrase and Other Endogenous Integrases}

ERVK integrase-like sequences were found in boreoeutherians, including the Euarchontoglires (primates, rodents, and pikas), and Laurasiatherians (ungulates), along with other clades including Euteleostomi (birds) and Protostomes (worms, insects, and water fleas) (Tables A2-A4). Results ranged from 26.43 to $83.77 \%$ identity and E values ranged from 0.001 to $2.0 \times 10^{-127}$, demonstrating a high degree of similarity with ERVK IN.

The conservation of ELM motifs was apparent (Table 2, Figure 2), including DDRrelated canonical 14-3-3 interaction motifs and WDR5 interaction, cell signaling associated with USP7 binding, IAP-binding motif, STAT5 binding motifs, SH3 protein interaction, as well as phosphorylation sites for CK proteins, GSK3, NEK2, polo-like kinases, and p38. Many LIR motifs for engaging Atg8 proteins during selective autophagy were also apparent. Finally, all IN displayed Pex14 binding motifs and potential to interact with the $\mu$-subunit of the adaptor protein complex. Additional ELMs and their motif frequencies in individual endogenous ERVK-like INs are listed in Table 2.

ELMs within endogenous IN but not or rarely identified in ERVK IN were also noted. An Apicomplexa-specific variant of the canonical LIR motif that binds to Atg8 protein family members was present in all endogenous INs except for ERVK IN. In addition, WDR5 binding motifs were much more prevalent in endogenous INs (5-12 sites) other than ERVK IN (only two sites). ERVK IN contained a single MAPK docking site for ERK/p38, whereas other endogenous INs contained several other motifs for MAPK interaction. Lastly, only human and macaque ERVK INs displayed high-affinity BRCT domain interaction motifs.

\subsection{Unlike Similar Enzymes, the ERVK Integrase Contains Distinct ELM Signatures}

Two motifs in ERVK IN stand out as unique to this virus, while other signatures are enriched in ERVK IN as compared with similar integrases.

\subsubsection{ERVK Integrase has a High-Affinity BRCA1 Binding Site}

Among all the integrases examined, only ERVK IN in human and macaque harbored a high-affinity binding site for the BRCT domain of BRCA1 (aa. 125-131, CSKAFQK) (Tables 1 and 2, Figures 1 and 2).

\subsubsection{ERVK Integrase C-Terminus Contains a 14-3-3 Binding RASTE Motif}

Although 14-3-3 protein binding was predicted as conserved among ERVK-like integrases, only ERVK IN contained a C-terminal RASTE motif (aa. 276-280) mediating strong interaction with 14-3-3 proteins (Table 1, Figure 1). This suggests a putative ERVK IN interaction with 14-3-3 proteins through both canonical phospho-sites and a C-terminal phospho-site.

\subsubsection{ERVK Integrase Is Likely Post-Translationally Sumoylated}

Unlike all other INs examined, only ERVK and MMTV contain a C-terminal inverted version (D/ExKphi) of the canonical sumoylation motif [67]. Considering that sumoylation often causes re-localization of nuclear proteins, this modification may be related to ERVK IN nuclear positioning, association with chromatin, and ultimately successful integration of viral DNA $[68,69]$.

\subsubsection{ERVK Integrase Exhibits Enhanced Interaction Potential with DDR Proteins}

Phospho-Ser/Thr binding domain proteins are key hub proteins in cell cycle regulation and DDR, and they include 14-3-3 proteins, WW domains, Polo-box domains, WD40 repeats, BRCA1 carboxy-terminal (BRCT) domains, and Forkhead-associated (FHA) domains [54], all 
of which are interacting domains of ELMs identified in ERVK IN (Tables 1 and 2, Figure 1). Additionally, ERVK IN contained five (ST)Q motifs, which are potential phosphorylation sites for PIKK proteins, such as DDR-related proteins ATR, ATM, DNA-PK, and multifunctional protein mTOR [70]. As compared with exogenous betaretroviruses and endogenous ERVK-like integrases, ERVK IN displayed a greater number of DDR-related motifs: FHA domain protein interaction sites (6), PLK-1 phosphorylation sites (4), and PP1c docking motif for target dephosphorylation (3) [50]. In contrast to MMTV, ENTV, JSRV, and most other endogenous integrases, fewer WD40 repeat domain WDR5 interaction sites were found in ERVK IN ( 2 vs. 5-12 sites each). This suggests ERVK IN has potentially shifted away from WDR5 interaction in favor of BRCA1 (or BRCT domain) interaction as a means to interact with the DDR pathway [54,71].

\subsubsection{ERVK Integrase Contains Canonical Selective Autophagy Motifs}

Unlike any of the exogenous betaretroviruses, only ERVK IN and some endogenous integrases contained canonical LIR motifs (ELME000368) for binding Atg8 protein family members (Tables 1 and 2, Figure 2). All endogenous INs contained nematode-specific LIR motifs (ELME000370). Additionally, most endogenous INs housed Apicomplexa-specific LIR motifs (ELME000369), whereas ERVK IN did not.

\subsection{ERVK Interactome Reveals Association with a Diversity of Cellular Pathways}

Based on ELMs identified in ERVK IN, a curated list of potential interacting proteins was generated and used to build an ERVK IN interactome network using STRING software (Figure 3). The ERVK IN network contained 189 nodes and 692 edges (expected number of edges 222), resulting in a significant PPI enrichment $\left(p<1.0 \times 10^{-16}\right)$. Only direct interactor query proteins are shown without links to second shell interactions. To illustrate key nodes and hub proteins, select network proteins were colored based on function related to DDR, cell cycle, apoptosis, cell signaling, or cellular transport. A complete list of the KEGG pathways significantly associated with the network is presented in Table A6.

\subsubsection{Many DNA Damage Response Proteins Are Potential ERVK Integrase Interactors}

Gene ontology (GO) biological processes that were significantly enriched in the network included cellular response to DNA damage stimulus $\left(p<4.4 \times 10^{-18}\right)$, DNA repair $\left(p<4.24 \times 10^{-12}\right)$, DNA damage checkpoint $\left(p<4.89 \times 10^{-12}\right)$, double-strand break repair via non-homologous end joining (NHEJ) $\left(p<3.57 \times 10^{-9}\right)$, double-strand break repair $\left(p<1.06 \times 10^{-8}\right)$, and signal transduction in response to DNA damage $\left(p<2.12 \times 10^{-8}\right)$. Select BRCT domain containing proteins emerged as nodes with a higher-than-average degree of connections, including BRCA1, BARD1, NBN, MDC1, RCF1, TOPBP1, TP53BP1, and PAXIP1, while PARP1 and DRKDC (DNA-PK) appear to be hub proteins between DDR and apoptosis. The ERVK IN network also displayed four prominent DDR-related FHA proteins: CHEK2, NBN, MDC1, and RNF8.

\subsubsection{ERVK Integrase Likely Modulates Cell Cycle Pathways}

GO biological processes that were significantly enriched in the network included regulation of cell cycle $\left(p<1.45 \times 10^{-33}\right)$, cell division $\left(p<1.12 \times 10^{-20}\right)$, regulation of cyclin-dependent serine/threonine kinase activity $\left(p<6.86 \times 10^{-20}\right)$, mitotic cell cycle $\left(p<2.78 \times 10^{-17}\right)$, regulation of apoptotic process $\left(p<1.45 \times 10^{-17}\right)$, and cell cycle checkpoint $\left(p<6.72 \times 10^{-12}\right)$. Many cyclins and 14-3-3 proteins were identified in the network and are listed in Table A5. IAP-containing protein BIRC5 (also known as survivin) was also identified, which is suggestive of negative regulation of programmed cell death pathways [72]. PLK1 and NEK2 were also tied into the cell cycle framework and are both regulators of mitosis, in addition to displaying oncogenic properties [73,74]. 


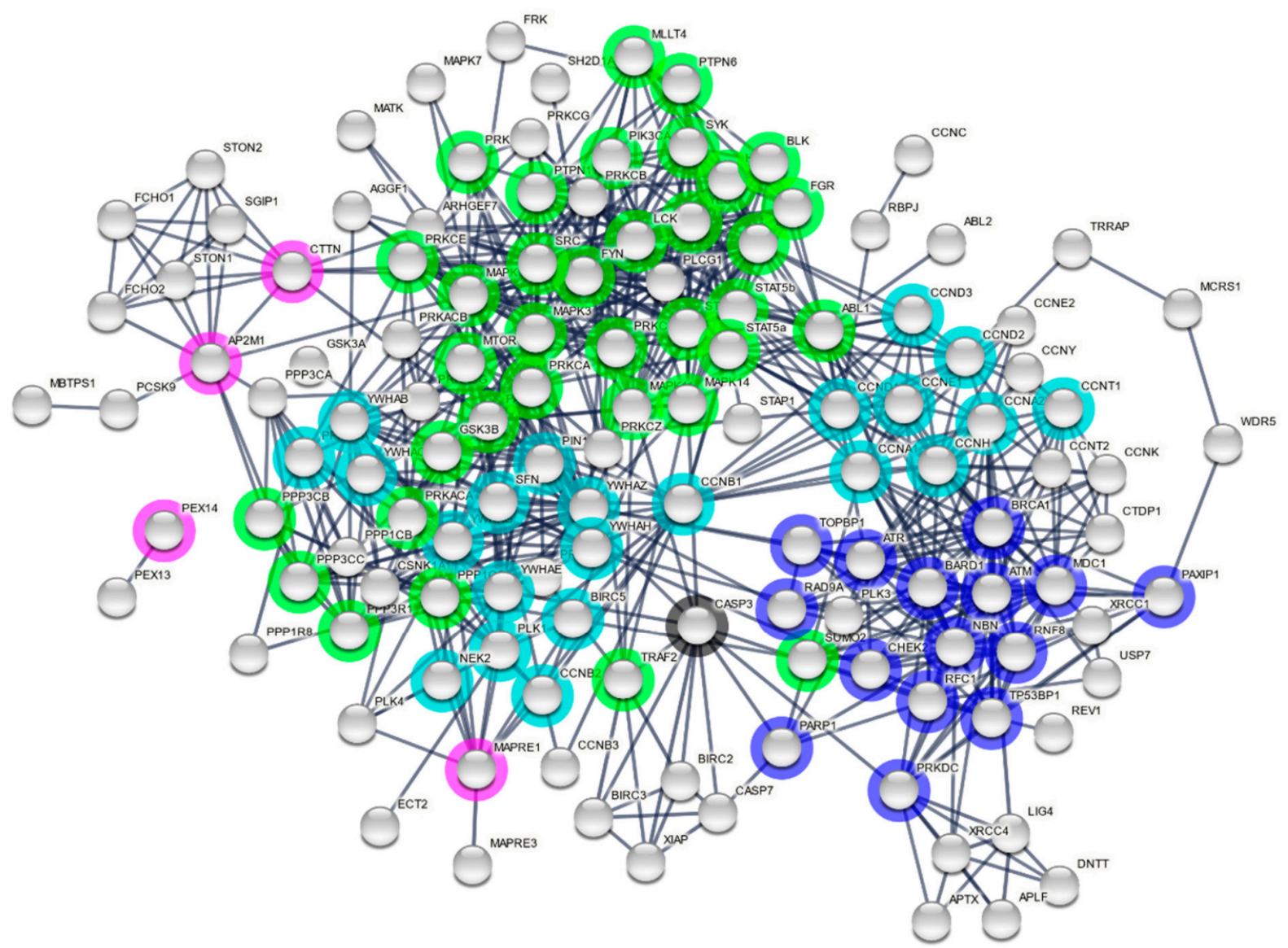

Figure 3. Predicted ERVK integrase interactome. Cellular proteins containing complementary interaction motifs for ELMs identified in Endogenous retrovirus-K (ERVK) integrase were listed as query proteins for STRING network analysis. Only query proteins with a minimum interaction score of 0.9 based on experiments and databases as interaction sources are indicated. Edges indicate both functional and physical protein associations. A payload list was generated to color nodes and hubs related to dominant pathways: DNA damage response (dark blue), cell cycle (cyan), apoptosis (black), cell signaling (green), and cell transport (magenta).

\subsubsection{Cell Signaling Pathways Associated with the ERVK Interactome}

Among the potential signaling pathways often targeted by retroviruses, ERVK INassociated cascades emerged as Forkhead box $\mathrm{O}$ (FoxO) signaling [75], p53 signaling [76], ErbB signaling [77], Wnt signaling [78], modulation of kinase activity [79,80], and multiple aspects of immune signaling [81] (Figure 4). Within these pathways, prominent immunerelated signaling intermediates included STAT3 [55], STAT5 [56], and TRAF2 [82]. The $\mathrm{SH} 2$ and $\mathrm{SH} 3$ containing tyrosine-protein kinase ABL1 (Abelson murine leukemia viral oncogene homolog 1 [57]) appears to be a key hub protein linking DDR and downstream signaling cascades.

\subsubsection{ERVK Integrase May Utilize Specific Cellular Transport Systems}

The ERVK interactome contains proteins related to cellular transport. EB1 (MAPRE1) is an end-binding (EB) protein connected with both cell cycle and signaling pathways and is functionally associated with the regulation of microtubule dynamics [83]. Adaptor protein complex 2 associated proteins (AP2M1 and CTTN) were identified and indicate a role in cargo internalization via clathrin-mediated endocytosis and actin dynamics [65,84]. Lastly, ERVK IN may interact with Pex14 and Pex13 independently of the main network for peroxisome import [63]. While these pathways were likely important for the ancestral exogenous ERVK to transverse the cell and mediate infection, it remains unclear how endogenous IN may interact with these systems. 


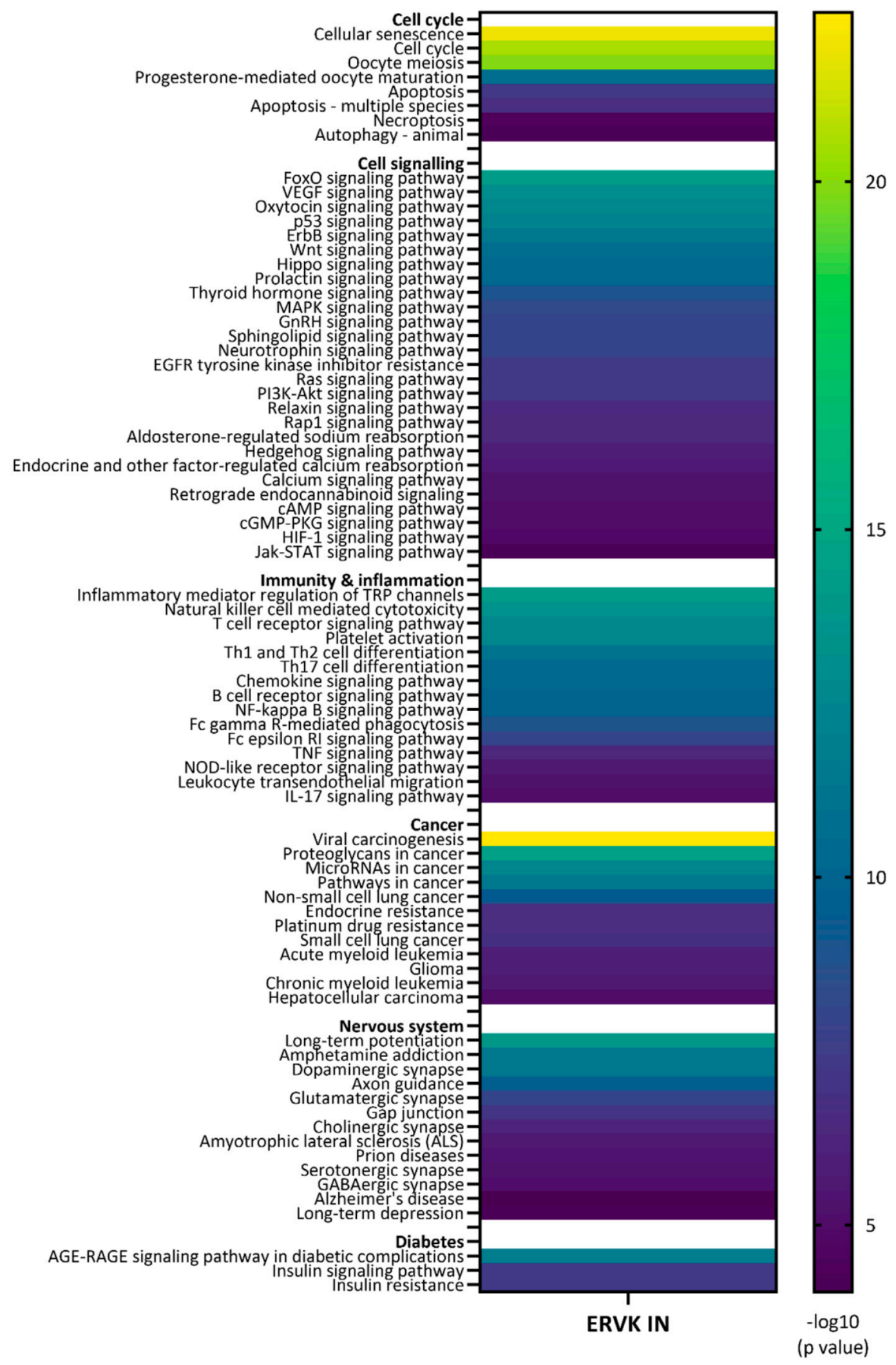

Figure 4. KEGG pathways associated with ERVK integrase interactome. Predicted interacting partners were curated based on ERVK IN ELM motifs and submitted to STRING network analysis software. Enriched KEGG pathways are reported along with significance scores $(-\log 10 p$ value). ERVK IN is predicted to interact with cellular pathways involved in the cell cycle, cell signaling, immunity, and inflammation, as well as disease pathways associated with several cancers, the nervous system, and diabetes. 


\subsection{Diseases and Pathways Implicated in the ERVK Integrase Interactome}

\subsubsection{Cancers}

Viral carcinogenesis was the top KEGG pathway identified in the ERVK IN network analysis (strength 1.22 , E value $3.7 \times 10^{-23}$ ), with 29 of 183 proteins represented (Figure 4). KEGG pathways for several known ERVK-associated cancers were also identified, including lung cancer [85], myeloid leukemia [86], and hepatocellular carcinoma [87] (Figure 4). Glioma was also identified, yet ERVK is downregulated in this condition [88]. Aligned with cellular transformation, proteins associated with cell cycle were also over-represented in the pathway analysis, which are specifically related to the cyclin docking site ELM (DOC_CYCLIN_RxL_1) and numerous FHA domain protein interaction sites (LIG_FHA_1 and LIG_FHA_2) in ERVK IN (Tables 1 and 2, Figures 1 and 2).

\subsubsection{Neurological Disease}

KEGG pathways for several ERVK-associated neurological conditions were identified, including ALS [9,12], Alzheimer's disease [89], and prion disease [90] (Figure 4). Specifically, long-term potentiation and synaptic neurotransmitter release (dopaminergic, glutamatergic, cholinergic, serotonergic, and GABAergic) were associated with the ERVK IN interactome.

\subsubsection{Diabetes}

The role of ERVK in diabetes remains contentious [91-94]. However, network analysis suggests that the ERVK IN interactome is potentially linked to AGE-RAGE signaling in diabetic complications, insulin signaling, and insulin resistance (Figure 4).

\section{Discussion}

ERVK expression has been repeatedly associated with human disease states including cancer, neurological disease, and diabetes. By exploring the potential ERVK integrase interactome, we can postulate how this viral symbiont may contribute to disease pathogenesis via interaction with key proteins and pathways. Our analysis reveals that viral carcinogenesis and modulation of the DNA damage response are the most likely pathways to be pathologically associated with ERVK IN expression.

Retroviral integrase activity causes DNA lesions in the host genome as part of the proviral integration process [19]; therefore, interactions with DDR pathways are to be expected. Several DDR proteins have been shown to be essential for provirus suture into the host genome and maintenance of genome fidelity [19]. Yet, the impairment of select aspects of DDR has also been documented in exogenous retroviral infections, including HIV $[95,96]$ and HTLV-1 $[97,98]$. This may be driven by the fact that NHEJ proteins also play an essential role in innate immune recognition of retroviral cytosolic ssDNA intermediates and dsDNA pre-integration complexes [98,99]. Thus, retroviruses must balance the benefits and drawbacks of DDR outcomes through the engagement and modulation of specific proteins.

BRCT domain, FHA domain, and 14-3-3 proteins work in concert during the DNA damage response (reviewed in [100]). Many of these DDR proteins are also cellular targets of retroviruses and oncogenic viruses [98,101-104]. BRCA1 BRCT domains recognize phosphopeptides based on a pSXXF motif, but XX residues and the surrounding amino acids also impact binding affinity and selectivity [105]. All the betaretroviral INs examined showed the capacity to interact with BRCT domains. However, only ERVK IN displayed a high affinity (S.F.K) BRCA1 BRCT domain binding site; the only other similar ELM structure is found in the DDR protein Fanconi anemia group J protein (FACJ/BACH1) [106]. It is also possible that dual anchoring onto the ERVK IN using both a BRCT domain and an FHA domain found in NBN or MDC1 may strengthen protein-protein interactions.

The utilization and evasion of 14-3-3 proteins are common among many viruses [104]. ERVK IN is unique in having a C-terminal RASTE motif, in addition to two other canonical arginine containing phospho-motifs recognized by 14-3-3 proteins. Given that an 
elevated expression of 14-3-3 proteins occurs in both cancers and neurodegenerative diseases $[107,108]$, ERVK IN interaction with 14-3-3 protein members may be related to either modulation of the cell cycle and oncogenesis or regulation of protein aggregation, respectively. The deregulation of 14-3-3 and RAF kinase interaction can also lead to inappropriate downstream MAPK activity (associated with oncogenesis) [54,109] and may be an aspect to consider for the predicted ERVK IN network.

ABL1 appears to be a key hub protein linking DDR and downstream signaling cascades. Interestingly, DDR is known to be a rapid driver of ABL1 activation [110]. The ablation of ABL1 reduces retrovirus integration [111,112], while active ABL1 can turn on the HIV promoter independently of HIV Tat [113]. Putative interaction between ERVK IN and ABL1 may have been important for ERVK integration into germline cells, and it may additionally play a role in ERVK expression, specifically in neurodegenerative disease displaying enhanced ABL1 activity [114,115].

DDR is intimately tied to innate immune response, specifically NF- $k B$ activation [116]. Considering ERVK's dependence on NF- $\mathrm{KB}$ for driving its own expression [11], it is conceivable that ERVK IN plays a role in preparing the host cell for viral transcription. 14-3-3e activity is key in driving ATM-TAK1-mediated NF- $\mathrm{KB}$ signaling during DDR [117,118]; thus, the predicted ERVK IN interaction with 14-3-3e (YWHAE) may be a mechanism to favor viral transcription. The MAPK p38 was also predicted to both phosphorylate and bind ERVK IN. This association may be linked to p38's regulation of inflammatory signaling, as well as its capacity to enhance the transcriptional activity of NF- $\mathrm{KB}$ p65 via modulation of the acetyltransferase activity of coactivator p300 [119]. Sustained NF- $k B$ activity is linked to oncogenesis [116] and ties into the strongest ERVK IN-linked KEGG pathway: viral carcinogenesis. However, enhanced ERVK IN-associated NF-KB signaling may also fit with inflammatory and neurodegenerative conditions.

ERVK IN stability and protein turnover is likely linked to its cellular protein partnerships. In the case of HIV, binding select cellular proteins such as LEDGF/p75 and Ku70 prevents integrase proteosomal degradation [120,121]. Similarly, c-Jun N-terminal kinase (JNK) $S^{57}$ phosphorylation of the core domain can make HIV IN a target for Pin1, thus enhancing its stability and activity [122,123]. In this study, Pin1's WW domain was predicted to be an interactor based on three [ST]P motifs in the C-terminal portion of ERVK IN. This raises the possibility that similar to many other viral proteins [124], ERVK IN may be stabilized through Pin1 interaction. The functional significance of this interaction may underlie how elevated levels of ERVK IN are maintained and potentially drive pathology in select diseases, such as ALS and cancer.

Distinct from other exogenous betaretroviruses, only ERVK IN and some endogenous integrases contained canonical LIR motifs for binding Atg8 protein family members. Mammalian Atg8-like proteins include LC3 and GABARAP families, which mediate selective autophagy, as well as play essential roles in antiviral defense and innate immune signaling [125]. However, it is often observed that viruses subvert autophagy processes to avoid viral protein clearance and repurpose Atg8 proteins as well as autophagosomal membranes for viral replication $[125,126]$. Considering the perturbances of autophagy in neurodegenerative disease $[127,128]$, the interaction between ERVK IN and Atg8 proteins warrants further investigation.

Consistent with genomic instability profiles in cancer [129], ALS [130], and Alzheimer's disease [131], the ERVK interactome analysis identified each of these conditions as significant KEGG pathways. Despite differences in clinical presentation, the molecular underpinnings in cancer and neurodegenerative disease are remarkably similar and include alterations in DDR [129,130,132], 14-3-3 expression [133,134], p53 signaling [135,136], p38 signaling $[137,138]$, and Wnt signaling $[139,140]$ —which are all KEGG pathways enriched in the ERVK IN network. AGE-RAGE signaling was also identified as a potential pathway associated with the ERVK IN interactome. Not only is this pathway implicated in diabetic complications [141], but it also plays a role in nuclear response to DNA damage [142], carcinogenesis [143], and inflammatory neurodegenerative diseases [144]. Collectively, our 
results point to ERVK IN driving a pattern of pathology that, depending on cellular context, may lead to carcinogenesis, neurodegeneration, or contribute to diabetic complications. However, the engagement of DDR can also have beneficial impacts on lifespan extension, depending on tissue context and host genotype; thus, non-pathogenic effects of ERVK IN should also be considered $[145,146]$.

Apart from the importance of putative ERVK IN interaction partners, it is also important to consider which cellular proteins were not associated with the ERVK IN interactome. One interaction that was not predicted was with LEDGF/p75, and indeed, this interactor is limited to partnership with lentiviral integrases [147,148]. Another set of DDR proteins commonly found to impact retroviral integration and replication is the DNA-PK complex [99,149]. HIV integrase directly interacts with Ku70 [120]; while ERVK IN was predicted to be phosphorylated by DNA-PKcs (PRKDC), it contained no ELMs to suggest direct interaction with $\mathrm{Ku} 80$ or Ku70. Another apparent difference is the use of EB proteins in microtubule trafficking for HIV and ERVK. ERVK IN contained an SxIP motif that binds EBH domains, whereas HIV capsid conversely has EB-like motifs that interact with SxIP motifs in plus-end tracking protein (+TIP) [150]. These genus-specific distinctions are likely to emerge as important considerations for therapeutic targeting strategies and imply that pharmaceuticals geared toward HIV infection may not consistently translate for use in ERVK-associated disease.

Another consideration that stems from this study is the choice and caveats of using animal models in ERVK research. A diversity of animals outside of the primate lineage are host to ERVK IN-like sequences, such as rodents, ungulates, fish, and insects. Drosophila, a common model organism, also contained ERVK IN-like elements in their genome, specifically LTR retrotransposons flea and Xanthias, as identified by FlyBase (Table A4). The transposable element Xanthias is known to be active in D. melanogaster [151,152], and it shares a degree of similarity with ERVK IN. The presence and activity of these ERVs is an important factor to consider when performing experiments.

It is shocking how little we understand of the impact endogenous viral symbionts have on cellular functioning. Herein, we have predicted that ERVK IN may participate in the modulation of cellular pathways such as DDR, cell cycle regulation, and kinase signaling cascades by way of select protein interaction motifs. The main caveat of in silico predictions is the requirement for experimental validation; while research into ERVK IN is currently underway, this study suggests there remains a myriad of disease-related betaretroviral integrase interactions to explore.

Author Contributions: Data curation, methodology, validation, investigation, and formal analysis by S.B., I.B. and R.N.D. Conceptualization, supervision, project administration, resources, visualization, and funding acquisition by R.N.D. Writing original draft preparation and review and editing by R.N.D. and I.B. All authors have read and agreed to the published version of the manuscript.

Funding: This study was funded in part by the ALS Association (\#477) and a Discovery grant from Natural Sciences and Engineering Research Council of Canada (NSERC, RGPIN-2016-05761). S.B. was funded by the University of Winnipeg Wiegand Biology Undergraduate Research Fund.

Institutional Review Board Statement: Not applicable.

Informed Consent Statement: Not applicable.

Data Availability Statement: National Center for Biotechnology Information (NCBI; https: / www. ncbi.nlm.nih.gov/, (accessed on 12 July 2021)) can be used to access sequences listed in the paper.

Acknowledgments: The authors would like to thank Samuel Narvey, Megan Rempel and Alex Vandenakker for their peer review of the manuscript drafts.

Conflicts of Interest: The authors declare no conflict of interest. The funders had no role in the design of the study; in the collection, analyses, or interpretation of data; in the writing of the manuscript, or in the decision to publish the results.

Dedication: This study is dedicated to patients with ALS-we are working on it! 


\section{Appendix A}

Table A1. Exogenous viruses with similarity to ERVK integrase based on BLASTp search.

\begin{tabular}{|c|c|c|c|c|c|c|c|}
\hline Hos & Species & Protein Name & $\begin{array}{l}\text { Accession } \\
\text { Number }\end{array}$ & Database & Percent Identity & E Value & Alignment \\
\hline & & & Retroviridae-1 & retrovirus & & & \\
\hline & & $\begin{array}{l}\text { MMTV strain BR6 } \\
\text { Integrase, partial }\end{array}$ & 5CZ2_A & $\mathrm{nr}$ & $56.46 \%$ & $3.00 \times 10^{-71}$ & \\
\hline & & Unnamed protein product & CAA25954.1 & $\mathrm{nr}$ & $52.36 \%$ & $2.00 \times 10^{-70}$ & \\
\hline & $\sum_{5}^{\infty}$ & $\begin{array}{l}\text { Chain A. Integrase } \\
\text { (Core model of the } \\
\text { MMTV Intasome) }\end{array}$ & 3JCA_A & $\mathrm{nr}$ & $51.50 \%$ & $2.00 \times 10^{-82}$ & \\
\hline & & Pr160 & NP_056880.1 & $\mathrm{nr}$ & $51.11 \%$ & $7.00 \times 10^{-76}$ & \\
\hline $\overrightarrow{\widetilde{Z}}$ & $P_{2}^{E}$ & Pr160 gag pro pol precursor & AAA46542.1 & $\mathrm{nr}$ & $51.11 \%$ & $7.00 \times 10^{-76}$ & \\
\hline$\sum_{\infty}^{2}$ & ప్ & p30DU-p13PR-RT-IN & NP_955564.1 & $\mathrm{nr}$ & $51.11 \%$ & $2.00 \times 10^{-76}$ & \\
\hline$\sum_{i}^{\infty}$ & 己્ટ & Gag-Pro-Pol polyprotein & P11283.2 & $\mathrm{nr}$ & $51.11 \%$ & $3.00 \times 10^{-75}$ & \\
\hline & & MMTV putative integrase & AAC24859.1 & $\mathrm{nr}$ & $50.37 \%$ & $5.00 \times 10^{-81}$ & \\
\hline & $\sum_{\Sigma}^{0}$ & $\begin{array}{c}\text { Gag-Pol-Pro } \\
\text { polyprotein, partial }\end{array}$ & BAA03767.1 & $\mathrm{nr}$ & $49.65 \%$ & $1.00 \times 10^{-77}$ & \\
\hline & & $\begin{array}{l}\text { Exogenous MMTV } \\
\text { Gag-Pro-Pol }\end{array}$ & AAF31469.1 & $\mathrm{nr}$ & $49.65 \%$ & $4.00 \times 10^{-76}$ & $\bullet$ \\
\hline & & $\begin{array}{l}\text { Endogenous MTV1 } \\
\text { Gag-Pro-Pol }\end{array}$ & AAF31464.1 & $\mathrm{nr}$ & $49.65 \%$ & $4.00 \times 10^{-76}$ & \\
\hline & & Pol protein, partial & AVG72436.1 & $\mathrm{nr}$ & $48.79 \%$ & $3.00 \times 10^{-72}$ & \\
\hline & & Pol protein, partial & AVG72437.1 & $\mathrm{nr}$ & $48.79 \%$ & $3.00 \times 10^{-71}$ & \\
\hline & & Pol protein, partial & AVG72438.1 & $\mathrm{nr}$ & $48.79 \%$ & $7.00 \times 10^{-71}$ & \\
\hline & & Pol protein, partial & AVG72441.1 & nr & $48.39 \%$ & $3.00 \times 10^{-71}$ & \\
\hline & & Pol protein, partial & AVG72440.1 & $\mathrm{nr}$ & $48.39 \%$ & $4.00 \times 10^{-71}$ & \\
\hline & & Pol protein, partial & AVG72435.1 & $\mathrm{nr}$ & $48.39 \%$ & $2.00 \times 10^{-70}$ & \\
\hline & & Gag-Pro-Pol protein & QBP05340.1 & $\mathrm{nr}$ & $47.41 \%$ & $3.00 \times 10^{-73}$ & \\
\hline & & Pol protein, partial & ANG58667.1 & $\mathrm{nr}$ & $47.41 \%$ & $2.00 \times 10^{-72}$ & \\
\hline & & Pol protein & QEQ26602.1 & $\mathrm{nr}$ & $47.41 \%$ & $3.00 \times 10^{-72}$ & \\
\hline$\stackrel{2}{3}$ & & Pol protein, partial & ANG58699.1 & $\mathrm{nr}$ & $47.41 \%$ & $2.00 \times 10^{-71}$ & $\bullet$ \\
\hline$\stackrel{\Xi}{\Xi}$ & 胥 & Pol protein, partial & ANG58695.1 & $\mathrm{nr}$ & $47.41 \%$ & $2.00 \times 10^{-71}$ & \\
\hline$\frac{5}{5}$ & 怘至 & Pol protein, partial & ANG58691.1 & $\mathrm{nr}$ & $47.41 \%$ & $2.00 \times 10^{-71}$ & \\
\hline & & Pol protein, partial & ANG58679.1 & $\mathrm{nr}$ & $47.41 \%$ & $5.00 \times 10^{-71}$ & \\
\hline & 式 & $\begin{array}{l}\text { Endogenous ENTV } \\
\text { pol protein }\end{array}$ & QPG92760.1 & $\mathrm{nr}$ & $47.41 \%$ & $3.00 \times 10^{-73}$ & \\
\hline & & $\begin{array}{l}\text { Endogenous ENTV } \\
\text { pol protein }\end{array}$ & QPG92768.1 & $\mathrm{nr}$ & $47.41 \%$ & $1.00 \times 10^{-72}$ & \\
\hline & & Gag-Pro-Pol, partial & AOZ60515.1 & $\mathrm{nr}$ & $47.04 \%$ & $1.00 \times 10^{-72}$ & \\
\hline & & Pol protein, partial & ANG58671.1 & $\mathrm{nr}$ & $47.04 \%$ & $1.00 \times 10^{-71}$ & \\
\hline & & Pol protein, partial & ANG58683.1 & $\mathrm{nr}$ & $47.04 \%$ & $3.00 \times 10^{-70}$ & \\
\hline & & Pol protein, partial & ANG58687.1 & $\mathrm{nr}$ & $47.04 \%$ & $2.00 \times 10^{-71}$ & \\
\hline & & Pol protein, partial & ANG58663.1 & $\mathrm{nr}$ & $47.04 \%$ & $8.00 \times 10^{-71}$ & \\
\hline
\end{tabular}


Table A1. Cont.

\begin{tabular}{|c|c|c|c|c|c|c|c|}
\hline \multicolumn{2}{|c|}{ Host Species } & Protein Name & $\begin{array}{l}\text { Accession } \\
\text { Number }\end{array}$ & Database & Percent Identity & E Value & Alignment \\
\hline & Gag-Pro-Pol protein & ANC55859.1 & $\mathrm{nr}$ & $46.67 \%$ & $5.00 \times 10^{-73}$ & \\
\hline & & Gag-Pro-Pol protein, partial & ADI50273.1 & $\mathrm{nr}$ & $46.67 \%$ & $4.00 \times 10^{-72}$ & \\
\hline & & Gag-Pro-Pol protein, partial & AOZ60519.1 & $\mathrm{nr}$ & $46.67 \%$ & $7.00 \times 10^{-72}$ & \\
\hline & & Pol protein, partial & ANG58675.1 & $\mathrm{nr}$ & $46.67 \%$ & $3.00 \times 10^{-71}$ & \\
\hline & & Gag-Pro-Pol fusion, partial & NP_862833.2 & $\mathrm{nr}$ & $46.67 \%$ & $7.00 \times 10^{-71}$ & \\
\hline & & Pol protein, partial & ANG58659.1 & $\mathrm{nr}$ & $46.10 \%$ & $1.00 \times 10^{-72}$ & \\
\hline \multirow{3}{*}{ 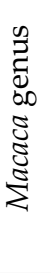 } & \multirow{3}{*}{ 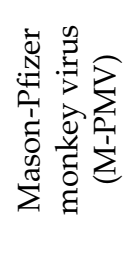 } & $\begin{array}{l}\text { Simian AIDS retrovirus } \\
\text { SRV-1-Pol polyprotein }\end{array}$ & GNLJSA & $\mathrm{nr}$ & $48.30 \%$ & $2.00 \times 10^{-70}$ & \\
\hline & & $\begin{array}{l}\text { Simian retrovirus } \\
\text { SRV-5-Pol polyprotein }\end{array}$ & BBG56792.1 & $\mathrm{nr}$ & $47.57 \%$ & $5.00 \times 10^{-71}$ & $\bullet$ \\
\hline & & $\begin{array}{l}\text { Simian retrovirus SRV-Y-Pol } \\
\text { protein, partial }\end{array}$ & BAM71050.1 & $\mathrm{nr}$ & $47.57 \%$ & $2.00 \times 10^{-70}$ & \\
\hline \multirow{3}{*}{ 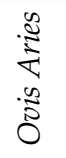 } & \multirow{3}{*}{ 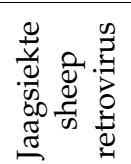 } & Reverse transcriptase, partial & CAA77117.1 & $\mathrm{nr}$ & $46.67 \%$ & $5.00 \times 10^{-75}$ & \\
\hline & & Reverse transcriptase, partial & CAA77113.1 & $\mathrm{nr}$ & $46.67 \%$ & $2.00 \times 10^{-74}$ & \\
\hline & & Pol protein & NP_041186.1 & $\mathrm{nr}$ & $46.30 \%$ & $1.00 \times 10^{-70}$ & $\bullet$ \\
\hline
\end{tabular}

BLAST databases: $\mathrm{nr}$ denotes non-redundant protein database. Circle symbol: denotes integrase sequences used in protein alignment in Figure 1.

Table A2. Boreoeutherian genomes with similarity to ERVK integrase based on BLASTp searches.

\begin{tabular}{|c|c|c|c|c|c|c|}
\hline & Species & Protein Name & $\begin{array}{l}\text { Accession } \\
\text { Number }\end{array}$ & Database & $\begin{array}{l}\text { Percent } \\
\text { Identity }\end{array}$ & E Value \\
\hline \multirow{18}{*}{ 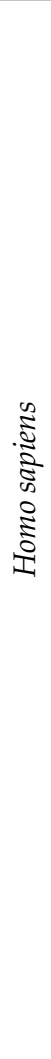 } & \multirow{18}{*}{ 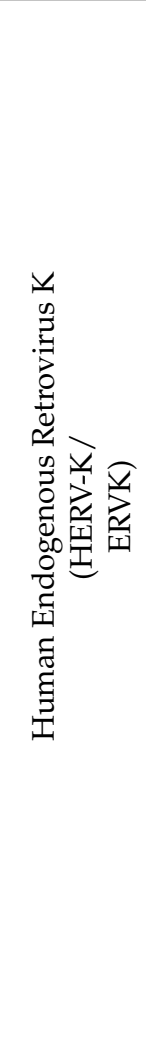 } & $\begin{array}{l}\text { Pol/env ORF (bases 3878-8257) first start codon at } \\
\text { 4172; Xxx; putative }\end{array}$ & AAA88033.1 & $\mathrm{nr}$ & $100.00 \%$ & 0 \\
\hline & & Endogenous retrovirus group K member 10 Pol protein & P10266.2 & $\mathrm{nr}$ & $100.00 \%$ & 0 \\
\hline & & Gag-Pro-Pol-Env protein & AAD51793.1 & $\mathrm{nr}$ & $100.00 \%$ & 0 \\
\hline & & Pol protein, partial & CAA71417.1 & $\mathrm{nr}$ & $100.00 \%$ & $2.00 \times 10^{-101}$ \\
\hline & & Endogenous retrovirus group $\mathrm{K}$ member 11 Pol protein & Q9UQG0.2 & $\mathrm{nr}$ & $99.64 \%$ & 0 \\
\hline & & Endogenous retrovirus group $\mathrm{K}$ member 7 Pol protein & P63135.1 & $\mathrm{nr}$ & $99.29 \%$ & 0 \\
\hline & & Reverse transcriptase, partial & AGQ55918.1 & $\mathrm{nr}$ & $99.28 \%$ & $1.00 \times 10^{-94}$ \\
\hline & & Reverse transcriptase, partial & AGQ55922.1 & $\mathrm{nr}$ & $99.28 \%$ & $7.00 \times 10^{-94}$ \\
\hline & & Polymerase, partial & AAO27434.1 & $\mathrm{nr}$ & $99.27 \%$ & 0 \\
\hline & & Gag-Pro-Pol protein & AAD51796.1 & $\mathrm{nr}$ & $99.17 \%$ & $5.00 \times 10^{-161}$ \\
\hline & & $\begin{array}{l}\text { Endogenous retrovirus group K member } \\
113 \text { Pol protein }\end{array}$ & P63132.1 & $\mathrm{nr}$ & $98.21 \%$ & 0 \\
\hline & & Polymerase, partial & AAK11553.1 & $\mathrm{nr}$ & $98.21 \%$ & 0 \\
\hline & & Endogenous retrovirus group $\mathrm{K}$ member 6 Pol protein & Q9BXR3.2 & $\mathrm{nr}$ & $98.21 \%$ & 0 \\
\hline & & Endogenous retrovirus group $\mathrm{K}$ member $8 \mathrm{Pol}$ protein & P63133.1 & $\mathrm{nr}$ & $98.21 \%$ & 0 \\
\hline & & Gag-Pro-Pol protein & AAD51797.1 & $\mathrm{nr}$ & $98.21 \%$ & 0 \\
\hline & & Pol protein & CAA76885.1 & $\mathrm{nr}$ & $97.86 \%$ & 0 \\
\hline & & Pol protein & CAA76879.1 & $\mathrm{nr}$ & $97.86 \%$ & 0 \\
\hline & & Polymerase, partial & AAK11554.1 & $\mathrm{nr}$ & $97.86 \%$ & 0 \\
\hline
\end{tabular}


Table A2. Cont.

\begin{tabular}{|c|c|c|c|c|c|}
\hline Species & Protein Name & $\begin{array}{l}\text { Accession } \\
\text { Number }\end{array}$ & Database & $\begin{array}{l}\text { Percent } \\
\text { Identity }\end{array}$ & E Value \\
\hline & Reverse transcriptase, partial & AGQ55928.1 & $\mathrm{nr}$ & $97.84 \%$ & $6.00 \times 10^{-93}$ \\
\hline & Reverse transcriptase, partial & AGQ55923.1 & nr & $97.84 \%$ & $8.00 \times 10^{-93}$ \\
\hline & Reverse transcriptase, partial & AGQ55925.1 & $\mathrm{nr}$ & $97.83 \%$ & $2.00 \times 10^{-92}$ \\
\hline & Reverse transcriptase, partial & AGQ55927.1 & nr & $97.83 \%$ & $3.00 \times 10^{-92}$ \\
\hline & Reverse transcriptase, partial & AGQ55914.1 & $\mathrm{nr}$ & $97.76 \%$ & $6.00 \times 10^{-89}$ \\
\hline & Pol protein & CAA76882.1 & $\mathrm{nr}$ & $97.50 \%$ & 0 \\
\hline & Endogenous retrovirus group K member 19 Pol protein & Q9WJR5.2 & $\mathrm{nr}$ & $97.50 \%$ & 0 \\
\hline & Endogenous retrovirus group $\mathrm{K}$ member $25 \mathrm{Pol}$ protein & P63136.1 & $\mathrm{nr}$ & $97.50 \%$ & 0 \\
\hline & Pol protein & AAL60056.1 & nr & $97.30 \%$ & $1.00 \times 10^{-152}$ \\
\hline & Reverse transcriptase, partial & AGQ55924.1 & $\mathrm{nr}$ & $97.12 \%$ & $2.00 \times 10^{-92}$ \\
\hline & Reverse transcriptase, partial & AGQ55926.1 & $\mathrm{nr}$ & $97.10 \%$ & $9.00 \times 10^{-92}$ \\
\hline & Reverse transcriptase, partial & AGQ55921.1 & $\mathrm{nr}$ & $97.10 \%$ & $9.00 \times 10^{-92}$ \\
\hline & Reverse transcriptase, partial & AGQ55919.1 & $\mathrm{nr}$ & $97.10 \%$ & $1.00 \times 10^{-91}$ \\
\hline & Pol/env protein, partial & AET81039.1 & $\mathrm{nr}$ & $96.97 \%$ & $1.00 \times 10^{-81}$ \\
\hline & Reverse transcriptase, partial & AGQ55920.1 & $\mathrm{nr}$ & $96.38 \%$ & $2.00 \times 10^{-91}$ \\
\hline & Pol protein & CAB56603.1 & $\mathrm{nr}$ & $90.13 \%$ & $2.00 \times 10^{-132}$ \\
\hline & Endogenous retrovirus group $\mathrm{K}$ member 18 Pol protein & Q9QC07.2 & $\mathrm{nr}$ & $90.13 \%$ & $2.00 \times 10^{-130}$ \\
\hline & hCG1808534 & EAW92672.1 & $\mathrm{nr}$ & $87.38 \%$ & $3.00 \times 10^{-130}$ \\
\hline $\begin{array}{c}\text { Macaca } \\
\text { fascicularis }\end{array}$ & $\begin{array}{l}\text { PREDICTED: endogenous retrovirus group K member } \\
\qquad 8 \text { Pol protein-like }\end{array}$ & XP_015309771.1 & $\mathrm{nr}$ & $83.77 \%$ & $2.00 \times 10^{-127}$ \\
\hline $\begin{array}{l}\text { Chlorocebus } \\
\text { sabaeus }\end{array}$ & Pol protein, partial & BBC20786.1 & nr & $47.01 \%$ & $3.00 \times 10^{-70}$ \\
\hline $\begin{array}{l}\text { Oryctolagus } \\
\text { cuniculus }\end{array}$ & $\begin{array}{l}\text { PREDICTED: endogenous retrovirus group K member } \\
8 \text { Pol protein-like }\end{array}$ & XP_017205812.1 & $\mathrm{nr}$ & $49.82 \%$ & $1.00 \times 10^{-76}$ \\
\hline $\begin{array}{l}\text { Marmota } \\
\text { marmota }\end{array}$ & $\begin{array}{l}\text { PREDICTED: endogenous retrovirus group K member } \\
11 \text { Pol protein-like }\end{array}$ & XP_015349278.1 & $\mathrm{nr}$ & $47.96 \%$ & $4.00 \times 10^{-71}$ \\
\hline $\begin{array}{l}\text { Ochotona } \\
\text { princeps }\end{array}$ & Uncharacterized protein LOC105942652 & XP_012786727.1 & $\mathrm{nr}$ & $47.33 \%$ & $1.00 \times 10^{-70}$ \\
\hline \multirow{7}{*}{$\begin{array}{c}\text { Mus } \\
\text { musculus } \\
\text { (mouse) }\end{array}$} & Agouti-signaling protein isoform $\mathrm{X} 1$ & XP_017174599.2 & mo & $46.93 \%$ & $6.00 \times 10^{-70}$ \\
\hline & Contactin-5 isoform $\mathrm{X} 2$ & XP_036010832.1 & mo & $44.11 \%$ & $3.00 \times 10^{-63}$ \\
\hline & Contactin- 5 isoform $\mathrm{X} 1$ & XP_036010831.1 & mo & $44.11 \%$ & $4.00 \times 10^{-63}$ \\
\hline & Contactin-5 isoform $\mathrm{X} 3$ & XP_036010833.1 & mo & $44.11 \%$ & $4.00 \times 10^{-63}$ \\
\hline & Protein NYNRIN-like isoform X1 & XP_036020530.1 & mo & $30.15 \%$ & $9.00 \times 10^{-14}$ \\
\hline & Uncharacterized protein Gm39701 & XP_011237194.2 & mo & $30.15 \%$ & $9.00 \times 10^{-14}$ \\
\hline & Uncharacterized protein LOC118567641, partial & XP_036010828.1 & mo & $29.71 \%$ & $2.00 \times 10^{-12}$ \\
\hline $\begin{array}{l}\text { Fukomys } \\
\text { damarensis }\end{array}$ & Pol polyprotein & KFO35018.1 & $\mathrm{nr}$ & $45.14 \%$ & $1.00 \times 10^{-71}$ \\
\hline
\end{tabular}


Table A2. Cont.

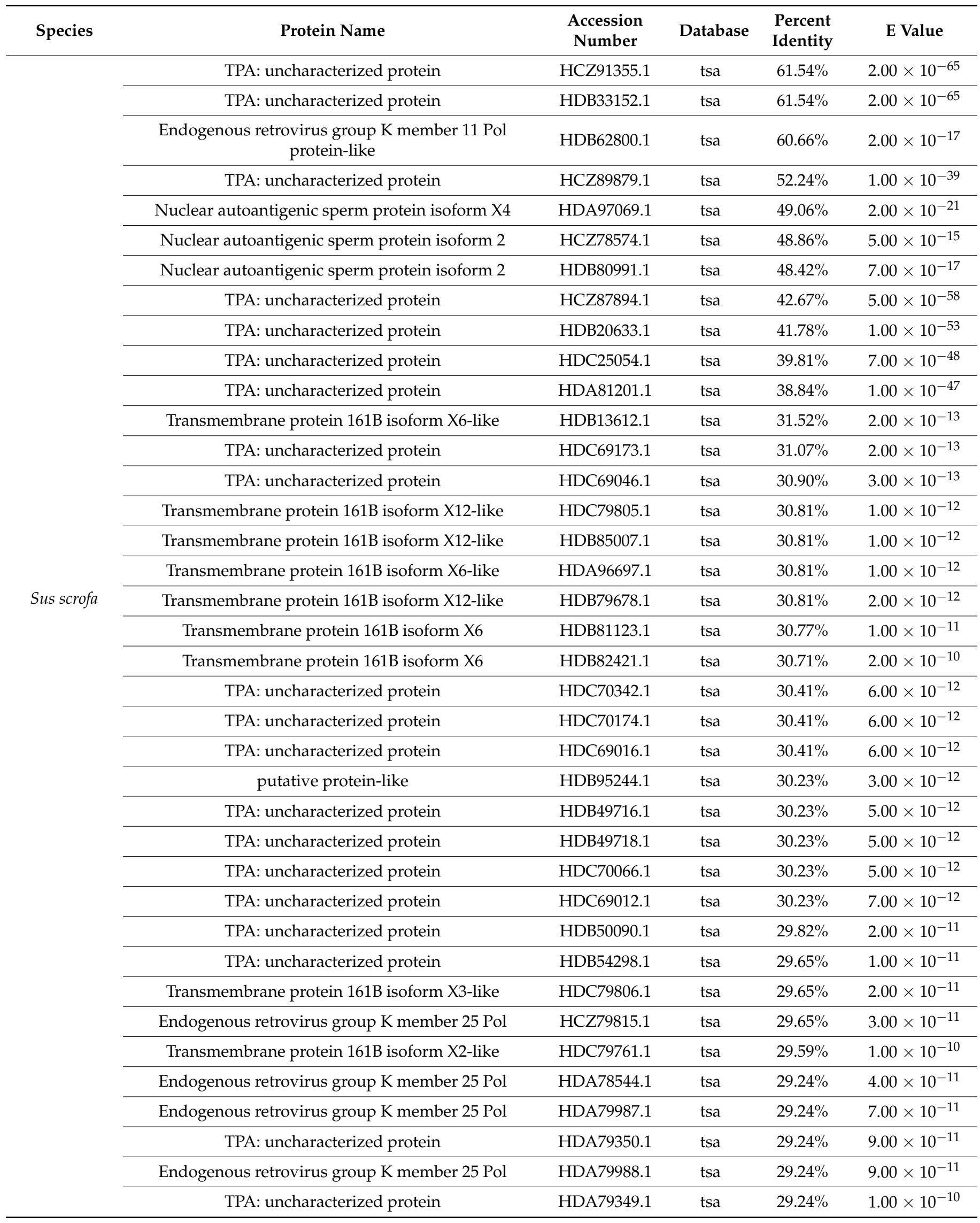


Table A2. Cont.

\begin{tabular}{|c|c|c|c|c|c|}
\hline Species & Protein Name & $\begin{array}{l}\text { Accession } \\
\text { Number }\end{array}$ & Database & $\begin{array}{l}\text { Percent } \\
\text { Identity }\end{array}$ & E Value \\
\hline & TPA: uncharacterized protein & HDC13198.1 & tsa & $29.24 \%$ & $1.00 \times 10^{-10}$ \\
\hline & Transmembrane protein 161B isoform X6-like & HDB88647.1 & tsa & $29.07 \%$ & $3.00 \times 10^{-11}$ \\
\hline & TPA: uncharacterized protein & HDA61679.1 & tsa & $29.07 \%$ & $5.00 \times 10^{-11}$ \\
\hline & TPA: uncharacterized protein & HDB82700.1 & tsa & $29.07 \%$ & $1.00 \times 10^{-10}$ \\
\hline Equus asinus & $\begin{array}{l}\text { PREDICTED: endogenous retrovirus group K } \\
\text { member } 8 \text { Pol protein-like }\end{array}$ & XP_014715024.1 & $\mathrm{nr}$ & $56.46 \%$ & $3.00 \times 10^{-95}$ \\
\hline Capra hircus & $\begin{array}{l}\text { PREDICTED: LOW QUALITY } \\
\text { PROTEIN: endogenous retrovirus group K } \\
\text { member } 18 \text { Pol protein-like }\end{array}$ & XP_017905435.1 & $\mathrm{nr}$ & $47.41 \%$ & $3.00 \times 10^{-71}$ \\
\hline \multirow{8}{*}{ Ovis aries } & Pol protein & ABV71120.1 & $\mathrm{nr}$ & $47.04 \%$ & $2.00 \times 10^{-72}$ \\
\hline & Pol protein & ABV71104.1 & $\mathrm{nr}$ & $46.67 \%$ & $4.00 \times 10^{-71}$ \\
\hline & Pol protein & ABV71084.1 & $\mathrm{nr}$ & $46.67 \%$ & $4.00 \times 10^{-71}$ \\
\hline & Pol protein & ABV71074.1 & $\mathrm{nr}$ & $46.67 \%$ & $4.00 \times 10^{-71}$ \\
\hline & Pol protein & ABV71079.1 & $\mathrm{nr}$ & $46.67 \%$ & $4.00 \times 10^{-71}$ \\
\hline & Pol protein & ABV71069.1 & $\mathrm{nr}$ & $46.67 \%$ & $4.00 \times 10^{-71}$ \\
\hline & Pol protein (endogenous virus) & AST51848.1 & $\mathrm{nr}$ & $46.67 \%$ & $5.00 \times 10^{-71}$ \\
\hline & Pol protein & ABV71094.1 & $\mathrm{nr}$ & $46.30 \%$ & $2.00 \times 10^{-70}$ \\
\hline
\end{tabular}

BLAST databases: $\mathrm{nr}=$ non-redundant protein database; $\mathrm{mo}=$ model organisms database; tsa = transcriptomics shotgun analysis nonredundant database. TPA = third party annotation.

Table A3. Euteleostomi genomes with similarity to ERVK integrase based on BLASTp searches.

\begin{tabular}{|c|c|c|c|c|c|}
\hline Species & Protein Name & $\begin{array}{l}\text { Accession } \\
\text { Number }\end{array}$ & $\begin{array}{l}\text { Data } \\
\text { base }\end{array}$ & Percent Identity & E Value \\
\hline \multirow{4}{*}{$\begin{array}{c}\text { Micrurus } \\
\text { lemniscatus } \\
\text { carvalhoi }\end{array}$} & Hypothetical protein, partial & LAA32932.1 & tsa & $58.47 \%$ & $2.00 \times 10^{-40}$ \\
\hline & Hypothetical protein, partial & LAA32929.1 & tsa & $57.63 \%$ & $6.00 \times 10^{-40}$ \\
\hline & Hypothetical protein, partial & LAA32939.1 & tsa & $48.29 \%$ & $4.00 \times 10^{-54}$ \\
\hline & Hypothetical protein, partial & LAA32941.1 & tsa & $44.00 \%$ & $1.00 \times 10^{-26}$ \\
\hline $\begin{array}{l}\text { Zosterops } \\
\text { borbonicus }\end{array}$ & $\begin{array}{l}\text { Hypothetical protein } \\
\text { HGM15179_011615 }\end{array}$ & TRZ15504.1 & $\mathrm{nr}$ & $46.97 \%$ & $3.00 \times 10^{-71}$ \\
\hline $\begin{array}{l}\text { Zonotrichia } \\
\text { albicollis }\end{array}$ & $\begin{array}{l}\text { Uncharacterized protein } \\
\text { LOC106629581 }\end{array}$ & XP_014125095.1 & $\mathrm{nr}$ & $46.24 \%$ & $1.00 \times 10^{-71}$ \\
\hline \multirow{2}{*}{$\begin{array}{l}\text { Micrurus } \\
\text { corallinus }\end{array}$} & Hypothetical protein, partial & LAA64555.1 & tsa & $46.21 \%$ & $2.00 \times 10^{-26}$ \\
\hline & Hypothetical protein, partial & LAA64556.1 & tsa & $45.08 \%$ & $2.00 \times 10^{-21}$ \\
\hline \multirow{2}{*}{$\begin{array}{c}\text { Micrurus } \\
\text { lemniscatus } \\
\text { lemniscatus }\end{array}$} & Hypothetical protein, partial & LAA89554.1 & tsa & $44.57 \%$ & $4.00 \times 10^{-18}$ \\
\hline & Hypothetical protein, partial & LAA89545.1 & tsa & $43.75 \%$ & $1.00 \times 10^{-23}$ \\
\hline $\begin{array}{c}\text { Bird } \\
\text { metagenome }\end{array}$ & Gag-Pro-Pol polyprotein, partial & MBY11728.1 & tsa & $44.31 \%$ & $3.00 \times 10^{-43}$ \\
\hline $\begin{array}{l}\text { Gallirallus } \\
\text { okinawae }\end{array}$ & Hypothetical protein, partial & LAC45429.1 & tsa & $43.96 \%$ & $3.00 \times 10^{-57}$ \\
\hline $\begin{array}{l}\text { Fundulus } \\
\text { heteroclitus }\end{array}$ & Integrase core domain, partial & JAQ81073.1 & tsa & $35.05 \%$ & $2.00 \times 10^{-11}$ \\
\hline
\end{tabular}


Table A3. Cont.

\begin{tabular}{|c|c|c|c|c|c|}
\hline Species & Protein Name & $\begin{array}{l}\text { Accession } \\
\text { Number }\end{array}$ & $\begin{array}{l}\text { Data } \\
\text { base }\end{array}$ & Percent Identity & E Value \\
\hline \multirow{8}{*}{$\begin{array}{l}\text { Danio rerio } \\
\text { (zebrafish) }\end{array}$} & $\begin{array}{c}\text { Uncharacterized protein } \\
\text { LOC108190699 }\end{array}$ & XP_017212567.1 & mo & $33.64 \%$ & $4.00 \times 10^{-12}$ \\
\hline & Uncharacterized protein K02A2.6-like & XP_021334762.1 & mo & $30.18 \%$ & $4.00 \times 10^{-11}$ \\
\hline & Uncharacterized protein K02A2.6-like & XP_017210639.2 & mo & $29.20 \%$ & $8.00 \times 10^{-9}$ \\
\hline & $\begin{array}{l}\text { Uncharacterized protein } \\
\text { LOC101886116 }\end{array}$ & XP_021327301.1 & mo & $28.47 \%$ & $1.00 \times 10^{-5}$ \\
\hline & $\begin{array}{c}\text { Uncharacterized protein } \\
\text { LOC110439859 }\end{array}$ & XP_021332670.1 & mo & $28.17 \%$ & 0.001 \\
\hline & Uncharacterized protein K02A2.6-like & XP_003199161.1 & mo & $27.78 \%$ & $5.00 \times 10^{-10}$ \\
\hline & Uncharacterized protein K02A2.6-like & XP_002663225.3 & mo & $27.78 \%$ & $8.00 \times 10^{-10}$ \\
\hline & $\begin{array}{c}\text { Uncharacterized protein } \\
\text { LOC110438047 }\end{array}$ & XP_021323131.1 & mo & $26.43 \%$ & 0.006 \\
\hline $\begin{array}{l}\text { Nothobranchius } \\
\text { korthausae }\end{array}$ & Uncharacterized protein & SBQ67355.1 & tsa & $32.02 \%$ & $8.00 \times 10^{-11}$ \\
\hline $\begin{array}{l}\text { Nothobranchius } \\
\text { kadleci }\end{array}$ & Uncharacterized protein & SBP84572.1 & tsa & $32.00 \%$ & $8.00 \times 10^{-11}$ \\
\hline $\begin{array}{l}\text { Nothobranchius } \\
\text { furzeri }\end{array}$ & Uncharacterized protein & SBS54329.1 & tsa & $31.25 \%$ & $5.00 \times 10^{-13}$ \\
\hline $\begin{array}{l}\text { Nothobranchius } \\
\text { rachovii }\end{array}$ & Uncharacterized protein & SBS11479.1 & tsa & $30.07 \%$ & $2.00 \times 10^{-10}$ \\
\hline
\end{tabular}

BLAST databases: $\mathrm{nr}=$ non-redundant protein database; $\mathrm{mo}=$ model organisms database; tsa = transcriptomics shotgun analysis nonredundant database.

Table A4. Nephrozoa (non-boreoeutherian) genomes with similarity to ERVK integrase based on BLASTp searches.

\begin{tabular}{|c|c|c|c|c|c|}
\hline Species & Protein Name & $\begin{array}{l}\text { Accession } \\
\text { Number }\end{array}$ & $\begin{array}{l}\text { Data } \\
\text { base }\end{array}$ & $\begin{array}{l}\text { Percent } \\
\text { Identity }\end{array}$ & E Value \\
\hline Onchocerca flexuosa & Integrase core domain protein & OZC05619.1 & $\mathrm{nr}$ & $45.68 \%$ & $6.00 \times 10^{-73}$ \\
\hline \multirow{7}{*}{ Ixodes ricinus } & Putative tf2-11 polyprotein & MXV00662.1 & tsa & $35.81 \%$ & $2.00 \times 10^{-10}$ \\
\hline & Putative tick transposon, partial & JAP73380.1 & tsa & $30.67 \%$ & $1.00 \times 10^{-11}$ \\
\hline & Putative tick transposon, partial & JAR90689.1 & tsa & $30.67 \%$ & $6.00 \times 10^{-11}$ \\
\hline & Putative bell all, partial & JAA73039.1 & tsa & $30.00 \%$ & $2.00 \times 10^{-10}$ \\
\hline & Putative gypsy11-i sp, partial & JAP69562.1 & tsa & $30.00 \%$ & $2.00 \times 10^{-10}$ \\
\hline & Putative tick transposon, partial & JAR92200.1 & tsa & $28.06 \%$ & $4.00 \times 10^{-13}$ \\
\hline & Putative transposon tf2-9 polyprotein & MXV00940.1 & tsa & $27.37 \%$ & $9.00 \times 10^{-13}$ \\
\hline \multirow{2}{*}{ Littorina littorea } & Transposon Ty3-G Gag-Pol polyprotein & MBX96210.1 & tsa & $35.54 \%$ & $4.00 \times 10^{-12}$ \\
\hline & Transposon Ty3-I Gag-Pol polyprotein & MBX97975.1 & tsa & $30.00 \%$ & $4.00 \times 10^{-14}$ \\
\hline \multirow{7}{*}{ Ixodes scapularis } & Putative tick transposon, partial & MOY42200.1 & tsa & $34.29 \%$ & $4.00 \times 10^{-12}$ \\
\hline & Putative tick transposon, partial & MOY42203.1 & tsa & $32.67 \%$ & $2.00 \times 10^{-13}$ \\
\hline & Putative tick transposon, partial & MOY42202.1 & tsa & $32.67 \%$ & $7.00 \times 10^{-13}$ \\
\hline & Putative gypsy-17 ga-i, partial & MOY42236.1 & tsa & $31.09 \%$ & $2.00 \times 10^{-12}$ \\
\hline & Hypothetical protein, partial & MOY42219.1 & tsa & $30.00 \%$ & $6.00 \times 10^{-11}$ \\
\hline & Putative gypsy11-i sp, partial & MOY42209.1 & tsa & $29.17 \%$ & $7.00 \times 10^{-12}$ \\
\hline & Putative gypsy21-i sp, partial & MOY42223.1 & tsa & $29.17 \%$ & $8.00 \times 10^{-12}$ \\
\hline
\end{tabular}


Table A4. Cont.

\begin{tabular}{|c|c|c|c|c|c|}
\hline Species & Protein Name & $\begin{array}{l}\text { Accession } \\
\text { Number }\end{array}$ & $\begin{array}{l}\text { Data } \\
\text { base }\end{array}$ & $\begin{array}{l}\text { Percent } \\
\text { Identity }\end{array}$ & E Value \\
\hline & Putative tick transposon, partial & MOY42227.1 & tsa & $28.50 \%$ & $4.00 \times 10^{-13}$ \\
\hline & Putative tick transposon, partial & MOY42214.1 & tsa & $28.25 \%$ & $9.00 \times 10^{-11}$ \\
\hline & Putative gypsy-27 xt-i, partial & MOY35588.1 & tsa & $26.44 \%$ & $1.00 \times 10^{-10}$ \\
\hline \multirow{5}{*}{ Lygus hesperus } & $\begin{array}{c}\text { Retrotransposable element Tf2 protein } \\
\text { type 3, partial }\end{array}$ & JAQ12551.1 & tsa & $33.58 \%$ & $6.00 \times 10^{-13}$ \\
\hline & Uncharacterized protein & JAG20083.1 & tsa & $33.58 \%$ & $6.00 \times 10^{-13}$ \\
\hline & $\begin{array}{l}\text { Hypothetical protein, partial } \\
\text { CM83_13537, partial }\end{array}$ & JAG31779.1 & tsa & $29.93 \%$ & $5.00 \times 10^{-11}$ \\
\hline & $\begin{array}{l}\text { Uncharacterized protein, partial } \\
\text { K02A2.6, partial }\end{array}$ & JAG32119.1 & tsa & $28.87 \%$ & $1.00 \times 10^{-11}$ \\
\hline & $\begin{array}{l}\text { Uncharacterized protein, partial } \\
\text { K02A2.6, partial }\end{array}$ & JAG38901.1 & tsa & $26.82 \%$ & $8.00 \times 10^{-12}$ \\
\hline \multirow{3}{*}{$\begin{array}{l}\text { Amblyomma } \\
\text { sculptum }\end{array}$} & Putative gypsy-7 adi-i, partial & JAU00762.1 & tsa & $32.88 \%$ & $1.00 \times 10^{-12}$ \\
\hline & Putative tick transposon, partial & JAU00733.1 & tsa & $30.00 \%$ & $2.00 \times 10^{-10}$ \\
\hline & Putative tick transposon, partial & JAU00744.1 & tsa & $30.00 \%$ & $2.00 \times 10^{-10}$ \\
\hline $\begin{array}{l}\text { Rhipicephalus } \\
\text { microplus }\end{array}$ & Putative tick transposon & NIE47479.1 & tsa & $32.45 \%$ & $4.00 \times 10^{-11}$ \\
\hline \multirow{8}{*}{$\begin{array}{l}\text { Strongylocentrotus } \\
\text { purpuratus }\end{array}$} & $\begin{array}{l}\text { Integrase, catalytic core } \\
\text { containing protein }\end{array}$ & MOS08875.1 & tsa & $32.19 \%$ & $2.00 \times 10^{-16}$ \\
\hline & $\begin{array}{l}\text { Integrase, catalytic core } \\
\text { containing protein }\end{array}$ & MOS08729.1 & tsa & $32.03 \%$ & $7.00 \times 10^{-13}$ \\
\hline & $\begin{array}{l}\text { Integrase, catalytic core } \\
\text { containing protein }\end{array}$ & MOS14051.1 & tsa & $30.57 \%$ & $2.00 \times 10^{-13}$ \\
\hline & $\begin{array}{l}\text { Reverse transcriptase } \\
\text { domain-containing protein }\end{array}$ & MOS08491.1 & tsa & $30.57 \%$ & $2.00 \times 10^{-13}$ \\
\hline & $\begin{array}{l}\text { Reverse transcriptase } \\
\text { domain-containing protein }\end{array}$ & MOS11069.1 & tsa & $29.93 \%$ & $5.00 \times 10^{-12}$ \\
\hline & $\begin{array}{l}\text { Integrase, catalytic core } \\
\text { containing protein }\end{array}$ & MOS08728.1 & tsa & $29.76 \%$ & $2.00 \times 10^{-10}$ \\
\hline & $\begin{array}{l}\text { Integrase, catalytic core } \\
\text { containing protein }\end{array}$ & MOS08842.1 & tsa & $28.57 \%$ & $4.00 \times 10^{-11}$ \\
\hline & $\begin{array}{l}\text { Integrase, catalytic core } \\
\text { containing protein }\end{array}$ & MOS08745.1 & tsa & $24.12 \%$ & $2.00 \times 10^{-10}$ \\
\hline $\begin{array}{l}\text { Ornithodoros } \\
\text { turicata }\end{array}$ & Putative transposon tf2-9 polyprotein & MBY06492.1 & tsa & $32.00 \%$ & $1.00 \times 10^{-10}$ \\
\hline $\begin{array}{l}\text { Ornithodoros } \\
\text { moubata }\end{array}$ & Esterase D, partial & JAW02195.1 & tsa & $29.86 \%$ & $2.00 \times 10^{-10}$ \\
\hline Photinus pyralis & Hypothetical protein & JAV53763.1 & tsa & $29.20 \%$ & $2.00 \times 10^{-13}$ \\
\hline $\begin{array}{l}\text { Lepeophtheirus } \\
\text { salmonis }\end{array}$ & $\begin{array}{l}\text { Uncharacterized protein } \\
\text { K02A2.6like, partial }\end{array}$ & CDW28658.1 & tsa & $28.28 \%$ & $1.00 \times 10^{-10}$ \\
\hline \multirow{4}{*}{$\begin{array}{l}\text { Drosophila } \\
\text { melanogaster } \\
\text { (Fruit fly) }\end{array}$} & Unnamed protein product & CAA30503.1 & nr-DM & $28.87 \%$ & 0.004 \\
\hline & Sd02026p & AAK84933.1 & nr-DM & $28.57 \%$ & $3.00 \times 10^{-9}$ \\
\hline & Blastopia polyprotein & CAA81643.1 & nr-DM & $28.19 \%$ & $2.00 \times 10^{-9}$ \\
\hline & Polyprotein & ACI62137.1 & nr-DM & $28.00 \%$ & $2.00 \times 10^{-4}$ \\
\hline
\end{tabular}

BLAST databases: $\mathrm{nr}=$ non-redundant protein database; $\mathrm{nr}-\mathrm{DM}=$ non-redundant protein database with Drosophila specified as species search constraint; tsa $=$ transcriptomics shotgun analysis non-redundant database. 
Table A5. List of query proteins for STRING analysis based on ELM interaction motifs in ERVK integrase.

\begin{tabular}{|c|c|c|c|}
\hline Category & ELM & $\begin{array}{l}\text { STRING Predicted Interactor } \\
\text { (Gene Name) }\end{array}$ & Network \\
\hline \multirow{11}{*}{ Cleavage } & \multirow{2}{*}{ CLV_C14_Caspase3-7 } & CASP3 & $\bullet$ \\
\hline & & CASP7 & $\bullet$ \\
\hline & \multirow{9}{*}{$\begin{array}{c}\text { CLV_PCSK_KEX2_1 } \\
\text { CLV_PCSK_PC1ET2_1 } \\
\text { CLV_PCSK_SKI1_1 }\end{array}$} & PCSK1 & $\bullet$ \\
\hline & & PCSK2 & $\bullet$ \\
\hline & & PCSK3 & $\bullet$ \\
\hline & & PCSK4 & $\bullet$ \\
\hline & & PCSK5 & $\bullet$ \\
\hline & & PCSK6 & $\bullet$ \\
\hline & & PCSK7 & $\bullet$ \\
\hline & & PCSK8 & $\bullet$ \\
\hline & & PCSK9 & $\bullet$ \\
\hline \multirow{29}{*}{ Docking site } & \multirow{29}{*}{ DOC_CYCLIN_RXL_1 } & CCNA1 & $\bullet$ \\
\hline & & CCNA2 & $\bullet$ \\
\hline & & CCNB1 & $\bullet$ \\
\hline & & CCNB2 & $\bullet$ \\
\hline & & CCNB3 & $\bullet$ \\
\hline & & CCNC & $\bullet$ \\
\hline & & CCND1 & $\bullet$ \\
\hline & & CCND2 & $\bullet$ \\
\hline & & CCND3 & $\bullet$ \\
\hline & & CCNE1 & $\bullet$ \\
\hline & & CCNE2 & $\bullet$ \\
\hline & & CCNF & $\bullet$ \\
\hline & & CCNG1 & $\bullet$ \\
\hline & & CCNG2 & $\bullet$ \\
\hline & & $\mathrm{CCNH}$ & $\bullet$ \\
\hline & & $\mathrm{CCNI}$ & $\bullet$ \\
\hline & & CCNI2 & $\bullet$ \\
\hline & & $\mathrm{CCNJ}$ & $\bullet$ \\
\hline & & CCNJL & $\bullet$ \\
\hline & & CCNK & $\bullet$ \\
\hline & & CCNL1 & $\bullet$ \\
\hline & & CCNL2 & $\bullet$ \\
\hline & & CCNO & $\bullet$ \\
\hline & & $\mathrm{CCNP}$ & $\bullet$ \\
\hline & & CCNT1 & $\bullet$ \\
\hline & & CCNT2 & $\bullet$ \\
\hline & & CCNY & $\bullet$ \\
\hline & & CCNYL1 & $\bullet$ \\
\hline & & CNTD1 & - \\
\hline
\end{tabular}


Table A5. Cont.

\begin{tabular}{|c|c|c|c|}
\hline Category & ELM & $\begin{array}{l}\text { STRING Predicted Interactor } \\
\text { (Gene Name) }\end{array}$ & Network \\
\hline & \multirow{5}{*}{ DOC_MAPK_MEF2A_6 } & MAPK1 & • \\
\hline & & MAPK3 & - \\
\hline & & MAPK7 & $\bullet$ \\
\hline & & MAPK11 & $\bullet$ \\
\hline & & MAPK14 & - \\
\hline & \multirow{6}{*}{ DOC_PP1_RVXF_1 } & PPP1CA & $\bullet$ \\
\hline & & PPP1CB & $\bullet$ \\
\hline & & PPP1CC & $\bullet$ \\
\hline & & РРР3СА & - \\
\hline & & РРР3СВ & $\bullet$ \\
\hline & & РРР3СС & $\bullet$ \\
\hline & DOC_PP2B_LxvP_1 & PPP3R1 & $\bullet$ \\
\hline & $\begin{array}{l}\text { DOC_USP7_MATH_1 } \\
\text { DOC_USP7_UBL2_3 }\end{array}$ & USP7 & $\bullet$ \\
\hline & \multirow{3}{*}{ DOC_WW_Pin1_4 } & PCIF1 & $\bullet$ \\
\hline & & PIN1 & $\bullet$ \\
\hline & & SENP6 & $\bullet$ \\
\hline & \multirow{7}{*}{$\begin{array}{l}\text { LIG_14-3-3_CanoR_1 } \\
\text { LIG_14-3-3_CterR_2 }\end{array}$} & SFN & $\bullet$ \\
\hline & & YWHAB & $\bullet$ \\
\hline & & YWHAE & $\bullet$ \\
\hline & & YWHAG & $\bullet$ \\
\hline & & YWHAH & $\bullet$ \\
\hline & & YWHAQ & $\bullet$ \\
\hline & & YWHAZ & $\bullet$ \\
\hline & \multirow{7}{*}{ LIG_BIR_II_1 } & BIRC2 & $\bullet$ \\
\hline & & BIRC3 & $\bullet$ \\
\hline & & BIRC5 & $\bullet$ \\
\hline & & BIRC6 & $\bullet$ \\
\hline & & BIRC7 & $\bullet$ \\
\hline & & NAIP & $\bullet$ \\
\hline & & XIAP & $\bullet$ \\
\hline & \multirow{9}{*}{ LIG_BRCT_BRCA1_1 } & BARD1 & $\bullet$ \\
\hline & & BRCA1 & $\bullet$ \\
\hline & & CTDP1 & $\bullet$ \\
\hline & & DNTT & $\bullet$ \\
\hline & & ECT2 & $\bullet$ \\
\hline & & LIG4 & $\bullet$ \\
\hline & & МСРH1 & $\bullet$ \\
\hline & & MDC1 & $\bullet$ \\
\hline & & NBN & - \\
\hline
\end{tabular}


Table A5. Cont.

\begin{tabular}{|c|c|c|c|}
\hline Category & ELM & $\begin{array}{l}\text { STRING Predicted Interactor } \\
\text { (Gene Name) }\end{array}$ & Network \\
\hline & & PARP1 & $\bullet$ \\
\hline & & PARP4 & $\bullet$ \\
\hline & & PAXIP1 & $\bullet$ \\
\hline & & PES1 & $\bullet$ \\
\hline & & RBPJ & $\bullet$ \\
\hline & & REV1 & - \\
\hline & & RFC1 & - \\
\hline & & TOPBP1 & $\bullet$ \\
\hline & & ТР53BP1 & $\bullet$ \\
\hline & & XRCC1 & - \\
\hline & \multirow{30}{*}{$\begin{array}{l}\text { LIG_FHA_1 } \\
\text { LIG_FHA_2 }\end{array}$} & AGGF1 & $\bullet$ \\
\hline & & APLF & $\bullet$ \\
\hline & & APTX & $\bullet$ \\
\hline & & CEP170 & $\bullet$ \\
\hline & & CEP170B & $\bullet$ \\
\hline & & CHEK2 & $\bullet$ \\
\hline & & CHFR & $\bullet$ \\
\hline & & FHAD1 & $\bullet$ \\
\hline & & FOXK1 & $\bullet$ \\
\hline & & FOXK2 & $\bullet$ \\
\hline & & KIF13A & $\bullet$ \\
\hline & & KIF13B & \\
\hline & & KIF14 & $\bullet$ \\
\hline & & KIF16B & \\
\hline & & KIF1A & - \\
\hline & & KIF1B & $\bullet$ \\
\hline & & KIF1C & \\
\hline & & MCRS1 & $\bullet$ \\
\hline & & MDC1 & $\bullet$ \\
\hline & & MKI67 & $\bullet$ \\
\hline & & MLLT4 & $\bullet$ \\
\hline & & NBN & $\bullet$ \\
\hline & & PHF12 & $\bullet$ \\
\hline & & PPP1R8 & $\bullet$ \\
\hline & & RNF8 & $\bullet$ \\
\hline & & SLC4A1AP & $\bullet$ \\
\hline & & SLMAP & $\bullet$ \\
\hline & & SNIP1 & $\bullet$ \\
\hline & & STARD9 & $\bullet$ \\
\hline & & TCF19 & $\bullet$ \\
\hline
\end{tabular}


Table A5. Cont.

\begin{tabular}{|c|c|c|c|}
\hline Category & ELM & $\begin{array}{l}\text { STRING Predicted Interactor } \\
\text { (Gene Name) }\end{array}$ & Network \\
\hline & & TIFA & $\bullet$ \\
\hline & & TIFAB & $\bullet$ \\
\hline & \multirow{5}{*}{ LIG_CSL_BTD_1 } & CHEK2 & $\bullet$ \\
\hline & & MRC1 & $\bullet$ \\
\hline & & RAD9A & $\bullet$ \\
\hline & & XRCC1 & • \\
\hline & & XRCC4 & $\bullet$ \\
\hline & \multirow{7}{*}{$\begin{array}{l}\text { LIG_LIR_Gen_1 } \\
\text { LIG_LIR_Nem_4 }\end{array}$} & GABARAP & \\
\hline & & GABARAPL1 & \\
\hline & & GABARAPL2 & $\bullet$ \\
\hline & & MAP1LC3A & \\
\hline & & MAP1LC3B & \\
\hline & & MAP1LC3B2 & $\bullet$ \\
\hline & & MAP1LC3C & \\
\hline & \multirow{2}{*}{ LIG_Pex14_1 } & PEX13 & $\bullet$ \\
\hline & & PEX14 & $\bullet$ \\
\hline & \multirow{2}{*}{ LIG_SH2_PTP2 } & PLCG1 & $\bullet$ \\
\hline & & PTPN11 & $\bullet$ \\
\hline & \multirow{9}{*}{ LIG_SH2_SRC } & BLK & $\bullet$ \\
\hline & & FGR & $\bullet$ \\
\hline & & FRK & • \\
\hline & & FYN & $\bullet$ \\
\hline & & HCK & $\bullet$ \\
\hline & & LCK & $\bullet$ \\
\hline & & LYN & $\bullet$ \\
\hline & & $\mathrm{SRC}$ & $\bullet$ \\
\hline & & YES1 & $\bullet$ \\
\hline & LIG_SH2_STAP1 & STAP1 & $\bullet$ \\
\hline & \multirow{13}{*}{ LIG_TYR_ITIM } & ABL1 & $\bullet$ \\
\hline & & ABL2 & $\bullet$ \\
\hline & & FYN & $\bullet$ \\
\hline & & LCK & $\bullet$ \\
\hline & & MATK & $\bullet$ \\
\hline & & PI3KCA & $\bullet$ \\
\hline & & PLCG1 & $\bullet$ \\
\hline & & SH2D1A & $\bullet$ \\
\hline & & SHF & $\bullet$ \\
\hline & & PTPN6 & $\bullet$ \\
\hline & & PTPN11 & $\bullet$ \\
\hline & & SRC & $\bullet$ \\
\hline & & SYK & $\bullet$ \\
\hline
\end{tabular}


Table A5. Cont.

\begin{tabular}{|c|c|c|c|}
\hline Category & ELM & $\begin{array}{c}\text { STRING Predicted Interactor } \\
\text { (Gene Name) }\end{array}$ & Network \\
\hline & LIG_SH2_STAT3 & STAT3 & $\bullet$ \\
\hline & \multirow{2}{*}{ LIG_SH2_STAT5 } & STAT5A & $\bullet$ \\
\hline & & STAT5B & - \\
\hline & \multirow{2}{*}{ LIG_SH3_3 } & ARHGEF7 & $\bullet$ \\
\hline & & CTTN & $\bullet$ \\
\hline & \multirow{3}{*}{ LIG_SxIP_EBH_1 } & MAPRE1 & - \\
\hline & & MAPRE2 & • \\
\hline & & MAPRE3 & $\bullet$ \\
\hline & LIG_TRAF2_1 & TRAF2 & $\bullet$ \\
\hline & LIG_WD40_WDR5_VDV_2 & WDR5 & - \\
\hline \multirow{28}{*}{ Modification } & MOD_CK1_1 & CSNK1A1 & $\bullet$ \\
\hline & MOD_CK2_1 & CSNK2A1 & $\bullet$ \\
\hline & \multirow{2}{*}{ MOD_GSK3_1 } & GSK3A & $\bullet$ \\
\hline & & GSK3B & - \\
\hline & MOD_N-GLC_1 & DDOST & $\bullet$ \\
\hline & MOD_NEK2_1 & NEK2 & $\bullet$ \\
\hline & \multirow{6}{*}{ MOD_PIKK_1 } & ATM & $\bullet$ \\
\hline & & ATR & $\bullet$ \\
\hline & & mTOR & $\bullet$ \\
\hline & & PRKDC & $\bullet$ \\
\hline & & SMG1 & $\bullet$ \\
\hline & & TRRAP & $\bullet$ \\
\hline & \multirow{12}{*}{ MOD_PKA_2 } & PAK1 & $\bullet$ \\
\hline & & PRKACA & $\bullet$ \\
\hline & & PRKACB & - \\
\hline & & PRKACG & $\bullet$ \\
\hline & & PRKCA & $\bullet$ \\
\hline & & PRKCB & $\bullet$ \\
\hline & & PRKCE & $\bullet$ \\
\hline & & PRKCG & $\bullet$ \\
\hline & & PRKCH & $\bullet$ \\
\hline & & PRKCI & - \\
\hline & & PRKCQ & $\bullet$ \\
\hline & & PRKCZ & $\bullet$ \\
\hline & \multirow{4}{*}{$\begin{array}{l}\text { MOD_Plk_1 } \\
\text { MOD_Plk_4 }\end{array}$} & PLK1 & $\bullet$ \\
\hline & & PLK2 & $\bullet$ \\
\hline & & PLK3 & - \\
\hline & & PLK4 & $\bullet$ \\
\hline
\end{tabular}


Table A5. Cont.

\begin{tabular}{|c|c|c|c|}
\hline Category & ELM & $\begin{array}{c}\text { STRING Predicted Interactor } \\
\text { (Gene Name) }\end{array}$ & Network \\
\hline & \multirow{4}{*}{ MOD_ProDKin_1 } & MAPK11 & $\bullet$ \\
\hline & & MAPK12 & \\
\hline & & MAPK13 & \\
\hline & & MAPK14 & $\bullet$ \\
\hline & MOD_SUMO_rev_2 & SUMO2 & $\bullet$ \\
\hline \multirow{13}{*}{ Targeting } & \multirow{12}{*}{ TRG_ENDOCYTIC_2 } & AP1M1 & $\bullet$ \\
\hline & & AP2M1 & $\bullet$ \\
\hline & & AP3M1 & $\bullet$ \\
\hline & & AP3M2 & \\
\hline & & AP4M1 & $\bullet$ \\
\hline & & AP5M1 & \\
\hline & & ARCN1 & \\
\hline & & FCHO1 & $\bullet$ \\
\hline & & FCHO2 & $\bullet$ \\
\hline & & SGIP1 & $\bullet$ \\
\hline & & STON1 & $\bullet$ \\
\hline & & STON2 & $\bullet$ \\
\hline & TRG_Pf-PMV_PEXEL_1 & None & \\
\hline
\end{tabular}

Circle symbol: denotes protein depicted in network analysis in Figure 3.

Table A6. Full list of KEGG pathways identified in the STRING analysis of the ERVK integrase interactome.

\begin{tabular}{|c|c|c|c|c|c|}
\hline KEGG Term ID & Term Description & $\begin{array}{l}\text { Observed Gene } \\
\text { Count }\end{array}$ & $\begin{array}{l}\text { Background Gene } \\
\text { Count }\end{array}$ & Strength & $\begin{array}{c}\text { False Discovery } \\
\text { Rate }\end{array}$ \\
\hline hsa04218 & Cellular senescence & 28 & 156 & 1.27 & $2.30 \times 10^{-23}$ \\
\hline hsa05203 & Viral carcinogenesis & 29 & 183 & 1.21 & $3.47 \times 10^{-23}$ \\
\hline hsa04110 & Cell cycle & 25 & 123 & 1.32 & $2.38 \times 10^{-22}$ \\
\hline hsa04114 & Oocyte meiosis & 23 & 116 & 1.31 & $2.13 \times 10^{-20}$ \\
\hline hsa05169 & $\begin{array}{c}\text { Epstein-Barr } \\
\text { virus infection }\end{array}$ & 24 & 194 & 1.11 & $4.01 \times 10^{-17}$ \\
\hline hsa05205 & Proteoglycans in cancer & 23 & 195 & 1.08 & $4.79 \times 10^{-16}$ \\
\hline hsa04650 & $\begin{array}{c}\text { Natural killer } \\
\text { cell-mediated cytotoxicity }\end{array}$ & 19 & 124 & 1.2 & $3.96 \times 10^{-15}$ \\
\hline hsa04068 & FoxO signaling pathway & 19 & 130 & 1.18 & $7.58 \times 10^{-15}$ \\
\hline hsa04750 & $\begin{array}{l}\text { Inflammatory mediator } \\
\text { regulation of } \\
\text { TRP channels }\end{array}$ & 17 & 92 & 1.28 & $8.12 \times 10^{-15}$ \\
\hline hsa05167 & $\begin{array}{c}\text { Kaposi's } \\
\text { sarcoma-associated } \\
\text { herpesvirus infection }\end{array}$ & 21 & 183 & 1.07 & $1.30 \times 10^{-14}$ \\
\hline hsa04720 & Long-term potentiation & 15 & 64 & 1.38 & $1.77 \times 10^{-14}$ \\
\hline hsa05161 & Hepatitis B & 19 & 142 & 1.14 & $2.19 \times 10^{-14}$ \\
\hline
\end{tabular}


Table A6. Cont.

\begin{tabular}{|c|c|c|c|c|c|}
\hline KEGG Term ID & Term Description & $\begin{array}{c}\text { Observed Gene } \\
\text { Count }\end{array}$ & $\begin{array}{c}\text { Background Gene } \\
\text { Count }\end{array}$ & Strength & $\begin{array}{c}\text { False Discovery } \\
\text { Rate }\end{array}$ \\
\hline hsa05206 & MicroRNAs in cancer & 19 & 149 & 1.12 & $4.49 \times 10^{-14}$ \\
\hline hsa04370 & VEGF signaling pathway & 14 & 59 & 1.39 & $1.11 \times 10^{-13}$ \\
\hline hsa04660 & $\begin{array}{c}\text { T cell receptor } \\
\text { signaling pathway }\end{array}$ & 16 & 99 & 1.22 & $2.39 \times 10^{-13}$ \\
\hline hsa04012 & ErbB signaling pathway & 15 & 83 & 1.27 & $3.37 \times 10^{-13}$ \\
\hline hsa04611 & Platelet activation & 17 & 123 & 1.15 & $3.37 \times 10^{-13}$ \\
\hline hsa04921 & $\begin{array}{c}\text { Oxytocin signaling } \\
\text { pathway }\end{array}$ & 18 & 149 & 1.09 & $4.19 \times 10^{-13}$ \\
\hline hsa04115 & p53 signaling pathway & 14 & 68 & 1.33 & $4.53 \times 10^{-13}$ \\
\hline hsa05200 & Pathways in cancer & 29 & 515 & 0.76 & $6.20 \times 10^{-13}$ \\
\hline hsa05166 & HTLV-I infection & 21 & 250 & 0.94 & $1.82 \times 10^{-12}$ \\
\hline hsa04933 & $\begin{array}{l}\text { AGE-RAGE signaling } \\
\text { pathway in diabetic } \\
\text { complications }\end{array}$ & 15 & 98 & 1.2 & $2.24 \times 10^{-12}$ \\
\hline hsa04510 & Focal adhesion & 19 & 197 & 1 & $2.57 \times 10^{-12}$ \\
\hline hsa04659 & Th17 cell differentiation & 15 & 102 & 1.18 & $3.46 \times 10^{-12}$ \\
\hline hsa05031 & Amphetamine addiction & 13 & 65 & 1.31 & $3.95 \times 10^{-12}$ \\
\hline hsa04728 & Dopaminergic synapse & 16 & 128 & 1.11 & $4.97 \times 10^{-12}$ \\
\hline hsa04658 & $\begin{array}{c}\text { Th1 and Th2 } \\
\text { cell differentiation }\end{array}$ & 14 & 88 & 1.21 & $7.29 \times 10^{-12}$ \\
\hline hsa05165 & $\begin{array}{l}\text { Human papillomavirus } \\
\text { infection }\end{array}$ & 22 & 317 & 0.85 & $1.27 \times 10^{-11}$ \\
\hline hsa04914 & $\begin{array}{l}\text { Progesterone-mediated } \\
\text { oocyte maturation }\end{array}$ & 14 & 94 & 1.19 & $1.52 \times 10^{-11}$ \\
\hline hsa04310 & Wnt signaling pathway & 16 & 143 & 1.06 & $2.02 \times 10^{-11}$ \\
\hline hsa04390 & Hippo signaling pathway & 16 & 152 & 1.04 & $4.56 \times 10^{-11}$ \\
\hline hsa04062 & $\begin{array}{c}\text { Chemokine signaling } \\
\text { pathway }\end{array}$ & 17 & 181 & 0.99 & $5.10 \times 10^{-11}$ \\
\hline hsa04917 & $\begin{array}{c}\text { Prolactin signaling } \\
\text { pathway }\end{array}$ & 12 & 69 & 1.25 & $1.03 \times 10^{-10}$ \\
\hline hsa04662 & $\begin{array}{c}\text { B cell receptor signaling } \\
\text { pathway }\end{array}$ & 12 & 71 & 1.24 & $1.35 \times 10^{-10}$ \\
\hline hsa04919 & $\begin{array}{l}\text { Thyroid hormone } \\
\text { signaling pathway }\end{array}$ & 14 & 115 & 1.1 & $1.47 \times 10^{-10}$ \\
\hline hsa04064 & $\begin{array}{c}\text { NF-kappa B } \\
\text { signaling pathway }\end{array}$ & 13 & 93 & 1.16 & $1.57 \times 10^{-10}$ \\
\hline hsa04270 & $\begin{array}{l}\text { Vascular smooth } \\
\text { muscle contraction }\end{array}$ & 14 & 119 & 1.08 & $2.11 \times 10^{-10}$ \\
\hline hsa04360 & Axon guidance & 16 & 173 & 0.98 & $2.24 \times 10^{-10}$ \\
\hline hsa05162 & Measles & 14 & 133 & 1.04 & $7.76 \times 10^{-10}$ \\
\hline hsa05223 & Non-small cell lung cancer & 11 & 66 & 1.23 & $9.08 \times 10^{-10}$ \\
\hline hsa04666 & $\begin{array}{c}\text { Fc gamma R-mediated } \\
\text { phagocytosis }\end{array}$ & 12 & 89 & 1.14 & $1.18 \times 10^{-9}$ \\
\hline hsa04380 & Osteoclast differentiation & 13 & 124 & 1.03 & $3.48 \times 10^{-9}$ \\
\hline
\end{tabular}


Table A6. Cont.

\begin{tabular}{|c|c|c|c|c|c|}
\hline KEGG Term ID & Term Description & $\begin{array}{l}\text { Observed Gene } \\
\text { Count }\end{array}$ & $\begin{array}{c}\text { Background Gene } \\
\text { Count }\end{array}$ & Strength & $\begin{array}{c}\text { False Discovery } \\
\text { Rate }\end{array}$ \\
\hline hsa01521 & $\begin{array}{l}\text { EGFR tyrosine kinase } \\
\text { inhibitor resistance }\end{array}$ & 11 & 78 & 1.16 & $4.18 \times 10^{-9}$ \\
\hline hsa04010 & MAPK signaling pathway & 18 & 293 & 0.8 & $5.87 \times 10^{-9}$ \\
\hline hsa04931 & Insulin resistance & 12 & 107 & 1.06 & $7.37 \times 10^{-9}$ \\
\hline hsa04910 & Insulin signaling pathway & 13 & 134 & 1 & $7.61 \times 10^{-9}$ \\
\hline hsa04724 & Glutamatergic synapse & 12 & 112 & 1.04 & $1.14 \times 10^{-8}$ \\
\hline hsa04151 & $\begin{array}{c}\text { PI3K-Akt } \\
\text { signaling pathway }\end{array}$ & 19 & 348 & 0.75 & $1.17 \times 10^{-8}$ \\
\hline hsa04912 & GnRH signaling pathway & 11 & 88 & 1.11 & $1.17 \times 10^{-8}$ \\
\hline hsa04664 & $\begin{array}{c}\text { Fc epsilon RI } \\
\text { signaling pathway }\end{array}$ & 10 & 67 & 1.19 & $1.30 \times 10^{-8}$ \\
\hline hsa04071 & $\begin{array}{c}\text { Sphingolipid signaling } \\
\text { pathway }\end{array}$ & 12 & 116 & 1.03 & $1.51 \times 10^{-8}$ \\
\hline hsa04722 & $\begin{array}{c}\text { Neurotrophin signaling } \\
\text { pathway }\end{array}$ & 12 & 116 & 1.03 & $1.51 \times 10^{-8}$ \\
\hline hsa01522 & Endocrine resistance & 11 & 95 & 1.08 & $2.24 \times 10^{-8}$ \\
\hline hsa04014 & Ras signaling pathway & 15 & 228 & 0.83 & $5.08 \times 10^{-8}$ \\
\hline hsa04210 & Apoptosis & 12 & 135 & 0.96 & $6.74 \times 10^{-8}$ \\
\hline hsa05152 & Tuberculosis & 13 & 172 & 0.89 & $1.01 \times 10^{-7}$ \\
\hline hsa04540 & Gap junction & 10 & 87 & 1.07 & $1.11 \times 10^{-7}$ \\
\hline hsa05221 & Acute myeloid leukemia & 9 & 66 & 1.15 & $1.42 \times 10^{-7}$ \\
\hline hsa05214 & Glioma & 9 & 68 & 1.13 & $1.74 \times 10^{-7}$ \\
\hline hsa05222 & Small cell lung cancer & 10 & 92 & 1.05 & $1.74 \times 10^{-7}$ \\
\hline hsa01524 & Platinum drug resistance & 9 & 70 & 1.12 & $2.13 \times 10^{-7}$ \\
\hline hsa04215 & $\begin{array}{c}\text { Apoptosis-multiple } \\
\text { species }\end{array}$ & 7 & 31 & 1.37 & $2.13 \times 10^{-7}$ \\
\hline hsa04926 & Relaxin signaling pathway & 11 & 130 & 0.94 & $3.72 \times 10^{-7}$ \\
\hline hsa04015 & Rap1 signaling pathway & 13 & 203 & 0.82 & $5.46 \times 10^{-7}$ \\
\hline hsa04960 & $\begin{array}{c}\text { Aldosterone-regulated } \\
\text { sodium reabsorption }\end{array}$ & 7 & 37 & 1.29 & $5.77 \times 10^{-7}$ \\
\hline hsa04668 & TNF signaling pathway & 10 & 108 & 0.98 & $6.23 \times 10^{-7}$ \\
\hline hsa04261 & $\begin{array}{l}\text { Adrenergic signaling in } \\
\text { cardiomyocytes }\end{array}$ & 11 & 139 & 0.91 & $6.58 \times 10^{-7}$ \\
\hline hsa05145 & Toxoplasmosis & 10 & 109 & 0.98 & $6.58 \times 10^{-7}$ \\
\hline hsa04725 & Cholinergic synapse & 10 & 111 & 0.97 & $7.54 \times 10^{-7}$ \\
\hline hsa05120 & $\begin{array}{l}\text { Epithelial cell signaling } \\
\text { in Helicobacter } \\
\text { pylori infection }\end{array}$ & 8 & 66 & 1.1 & $1.53 \times 10^{-6}$ \\
\hline hsa04340 & $\begin{array}{c}\text { Hedgehog signaling } \\
\text { pathway }\end{array}$ & 7 & 46 & 1.2 & $1.97 \times 10^{-6}$ \\
\hline hsa04961 & $\begin{array}{l}\text { Endocrine and other } \\
\text { factor-regulated } \\
\text { calcium reabsorption }\end{array}$ & 7 & 47 & 1.19 & $2.22 \times 10^{-6}$ \\
\hline
\end{tabular}


Table A6. Cont.

\begin{tabular}{|c|c|c|c|c|c|}
\hline KEGG Term ID & Term Description & $\begin{array}{l}\text { Observed Gene } \\
\text { Count }\end{array}$ & $\begin{array}{l}\text { Background Gene } \\
\text { Count }\end{array}$ & Strength & $\begin{array}{c}\text { False Discovery } \\
\text { Rate }\end{array}$ \\
\hline hsa04066 & HIF-1 signaling pathway & 9 & 98 & 0.98 & $2.44 \times 10^{-6}$ \\
\hline hsa04520 & Adherens junction & 8 & 71 & 1.06 & $2.44 \times 10^{-6}$ \\
\hline hsa04916 & Melanogenesis & 9 & 98 & 0.98 & $2.44 \times 10^{-6}$ \\
\hline hsa05225 & Hepatocellular carcinoma & 11 & 163 & 0.84 & $2.56 \times 10^{-6}$ \\
\hline hsa04621 & $\begin{array}{l}\text { NOD-like receptor } \\
\text { signaling pathway }\end{array}$ & 11 & 166 & 0.83 & $2.99 \times 10^{-6}$ \\
\hline hsa05014 & $\begin{array}{l}\text { Amyotrophic lateral } \\
\text { sclerosis (ALS) }\end{array}$ & 7 & 50 & 1.16 & $2.99 \times 10^{-6}$ \\
\hline hsa05220 & Chronic myeloid leukemia & 8 & 76 & 1.04 & $3.62 \times 10^{-6}$ \\
\hline hsa05020 & Prion diseases & 6 & 33 & 1.27 & $4.44 \times 10^{-6}$ \\
\hline hsa04020 & $\begin{array}{l}\text { Calcium signaling } \\
\text { pathway }\end{array}$ & 11 & 179 & 0.8 & $5.69 \times 10^{-6}$ \\
\hline hsa04670 & $\begin{array}{c}\text { Leukocyte } \\
\text { transendothelial migration }\end{array}$ & 9 & 112 & 0.92 & $6.16 \times 10^{-6}$ \\
\hline hsa04726 & Serotonergic synapse & 9 & 112 & 0.92 & $6.16 \times 10^{-6}$ \\
\hline hsa04723 & $\begin{array}{c}\text { Retrograde } \\
\text { endocannabinoid } \\
\text { signaling }\end{array}$ & 10 & 148 & 0.84 & $7.20 \times 10^{-6}$ \\
\hline hsa04727 & GABAergic synapse & 8 & 88 & 0.97 & $9.28 \times 10^{-6}$ \\
\hline hsa04934 & Cushing's syndrome & 10 & 153 & 0.83 & $9.30 \times 10^{-6}$ \\
\hline hsa04924 & Renin secretion & 7 & 63 & 1.06 & $1.09 \times 10^{-5}$ \\
\hline hsa04024 & cAMP signaling pathway & 11 & 195 & 0.76 & $1.14 \times 10^{-5}$ \\
\hline hsa04657 & IL-17 signaling pathway & 8 & 92 & 0.95 & $1.20 \times 10^{-5}$ \\
\hline hsa04022 & $\begin{array}{l}\text { cGMP-PKG signaling } \\
\text { pathway }\end{array}$ & 10 & 160 & 0.81 & $1.28 \times 10^{-5}$ \\
\hline hsa04140 & Autophagy_animal & 9 & 125 & 0.87 & $1.28 \times 10^{-5}$ \\
\hline hsa04630 & $\begin{array}{l}\text { Jak-STAT signaling } \\
\text { pathway }\end{array}$ & 10 & 160 & 0.81 & $1.28 \times 10^{-5}$ \\
\hline hsa04713 & Circadian entrainment & 8 & 93 & 0.95 & $1.28 \times 10^{-5}$ \\
\hline hsa05146 & Amoebiasis & 8 & 94 & 0.94 & $1.32 \times 10^{-5}$ \\
\hline hsa05215 & Prostate cancer & 8 & 97 & 0.93 & $1.62 \times 10^{-5}$ \\
\hline hsa05231 & $\begin{array}{c}\text { Choline metabolism } \\
\text { in cancer }\end{array}$ & 8 & 98 & 0.92 & $1.72 \times 10^{-5}$ \\
\hline hsa04371 & Apelin signaling pathway & 9 & 133 & 0.84 & $1.94 \times 10^{-5}$ \\
\hline hsa04930 & Type II diabetes mellitus & 6 & 46 & 1.13 & $2.04 \times 10^{-5}$ \\
\hline hsa03450 & $\begin{array}{l}\text { Non-homologous } \\
\text { end-joining }\end{array}$ & 4 & 13 & 1.5 & $3.50 \times 10^{-5}$ \\
\hline hsa04072 & $\begin{array}{l}\text { Phospholipase D } \\
\text { signaling pathway }\end{array}$ & 9 & 145 & 0.81 & $3.61 \times 10^{-5}$ \\
\hline hsa05226 & Gastric cancer & 9 & 147 & 0.8 & $3.96 \times 10^{-5}$ \\
\hline hsa05210 & Colorectal cancer & 7 & 85 & 0.93 & $5.70 \times 10^{-5}$ \\
\hline hsa04217 & Necroptosis & 9 & 155 & 0.78 & $5.77 \times 10^{-5}$ \\
\hline hsa04730 & Long-term depression & 6 & 60 & 1.01 & $7.67 \times 10^{-5}$ \\
\hline
\end{tabular}


Table A6. Cont.

\begin{tabular}{|c|c|c|c|c|c|}
\hline KEGG Term ID & Term Description & $\begin{array}{c}\text { Observed Gene } \\
\text { Count }\end{array}$ & $\begin{array}{c}\text { Background Gene } \\
\text { Count }\end{array}$ & Strength & $\begin{array}{c}\text { False Discovery } \\
\text { Rate }\end{array}$ \\
\hline hsa04925 & $\begin{array}{l}\text { Aldosterone synthesis } \\
\text { and secretion }\end{array}$ & 7 & 93 & 0.89 & $9.48 \times 10^{-5}$ \\
\hline hsa04530 & Tight junction & 9 & 167 & 0.74 & $9.70 \times 10^{-5}$ \\
\hline hsa05131 & Shigellosis & 6 & 63 & 0.99 & $9.70 \times 10^{-5}$ \\
\hline hsa05010 & Alzheimer's disease & 9 & 168 & 0.74 & $9.98 \times 10^{-5}$ \\
\hline hsa05164 & Influenza A & 9 & 168 & 0.74 & $9.98 \times 10^{-5}$ \\
\hline hsa05160 & Hepatitis C & 8 & 131 & 0.8 & 0.00011 \\
\hline hsa03440 & $\begin{array}{l}\text { Homologous } \\
\text { recombination }\end{array}$ & 5 & 40 & 1.11 & 0.00012 \\
\hline hsa04922 & $\begin{array}{c}\text { Glucagon signaling } \\
\text { pathway }\end{array}$ & 7 & 100 & 0.86 & 0.00014 \\
\hline hsa05140 & Leishmaniasis & 6 & 70 & 0.95 & 0.00016 \\
\hline hsa05168 & Herpes simplex infection & 9 & 181 & 0.71 & 0.00016 \\
\hline hsa04971 & Gastric acid secretion & 6 & 72 & 0.93 & 0.00018 \\
\hline hsa04918 & $\begin{array}{l}\text { Thyroid hormone } \\
\text { synthesis }\end{array}$ & 6 & 73 & 0.93 & 0.00019 \\
\hline hsa05133 & Pertussis & 6 & 74 & 0.92 & 0.0002 \\
\hline hsa05212 & Pancreatic cancer & 6 & 74 & 0.92 & 0.0002 \\
\hline hsa05224 & Breast cancer & 8 & 147 & 0.75 & 0.00021 \\
\hline hsa04150 & mTOR signaling pathway & 8 & 148 & 0.75 & 0.00022 \\
\hline hsa05110 & Vibrio cholerae infection & 5 & 48 & 1.03 & 0.00025 \\
\hline hsa04810 & $\begin{array}{c}\text { Regulation of } \\
\text { actin cytoskeleton }\end{array}$ & 9 & 205 & 0.66 & 0.00037 \\
\hline hsa04911 & Insulin secretion & 6 & 84 & 0.87 & 0.00037 \\
\hline hsa05130 & $\begin{array}{l}\text { Pathogenic Escherichia } \\
\text { coli infection }\end{array}$ & 5 & 53 & 0.99 & 0.00037 \\
\hline hsa04970 & Salivary secretion & 6 & 86 & 0.86 & 0.00041 \\
\hline hsa05416 & Viral myocarditis & 5 & 56 & 0.96 & 0.00046 \\
\hline hsa05032 & Morphine addiction & 6 & 91 & 0.83 & 0.00053 \\
\hline hsa05213 & Endometrial cancer & 5 & 58 & 0.95 & 0.00053 \\
\hline hsa04915 & $\begin{array}{l}\text { Estrogen signaling } \\
\text { pathway }\end{array}$ & 7 & 133 & 0.73 & 0.00063 \\
\hline hsa05418 & $\begin{array}{l}\text { Fluid shear stress } \\
\text { and atherosclerosis }\end{array}$ & 7 & 133 & 0.73 & 0.00063 \\
\hline hsa04213 & $\begin{array}{l}\text { Longevity regulating } \\
\text { pathway-multiple } \\
\text { species }\end{array}$ & 5 & 61 & 0.93 & 0.00064 \\
\hline hsa04550 & $\begin{array}{l}\text { Signaling pathways } \\
\text { regulating pluripotency of } \\
\text { stem cells }\end{array}$ & 7 & 138 & 0.72 & 0.00076 \\
\hline hsa05211 & Renal cell carcinoma & 5 & 68 & 0.88 & 0.001 \\
\hline hsa04920 & $\begin{array}{l}\text { Adipocytokine signaling } \\
\text { pathway }\end{array}$ & 5 & 69 & 0.87 & 0.0011 \\
\hline hsa05219 & Bladder cancer & 4 & 41 & 1 & 0.0013 \\
\hline
\end{tabular}


Table A6. Cont.

\begin{tabular}{|c|c|c|c|c|c|}
\hline KEGG Term ID & Term Description & $\begin{array}{l}\text { Observed Gene } \\
\text { Count }\end{array}$ & $\begin{array}{l}\text { Background Gene } \\
\text { Count }\end{array}$ & Strength & $\begin{array}{c}\text { False Discovery } \\
\text { Rate }\end{array}$ \\
\hline hsa04211 & $\begin{array}{c}\text { Longevity regulating } \\
\text { pathway }\end{array}$ & 5 & 88 & 0.77 & 0.0029 \\
\hline hsa04923 & $\begin{array}{l}\text { Regulation of lipolysis } \\
\text { in adipocytes }\end{array}$ & 4 & 53 & 0.89 & 0.0031 \\
\hline hsa04120 & $\begin{array}{l}\text { Ubiquitin mediated } \\
\text { proteolysis }\end{array}$ & 6 & 134 & 0.66 & 0.0033 \\
\hline hsa04070 & $\begin{array}{l}\text { Phosphatidylinositol } \\
\text { signaling system }\end{array}$ & 5 & 97 & 0.72 & 0.0043 \\
\hline hsa05034 & Alcoholism & 6 & 142 & 0.64 & 0.0043 \\
\hline hsa05142 & $\begin{array}{c}\text { Chagas disease } \\
\text { (American trypanosomiasis) }\end{array}$ & 5 & 101 & 0.71 & 0.005 \\
\hline hsa04620 & $\begin{array}{l}\text { Toll-like receptor } \\
\text { signaling pathway }\end{array}$ & 5 & 102 & 0.7 & 0.0051 \\
\hline hsa04932 & $\begin{array}{l}\text { Non-alcoholic fatty liver } \\
\text { disease (NAFLD) }\end{array}$ & 6 & 149 & 0.62 & 0.0053 \\
\hline hsa05230 & $\begin{array}{c}\text { Central carbon } \\
\text { metabolism in cancer }\end{array}$ & 4 & 65 & 0.8 & 0.0059 \\
\hline hsa03410 & Base excision repair & 3 & 33 & 0.97 & 0.0066 \\
\hline hsa05143 & African trypanosomiasis & 3 & 34 & 0.96 & 0.0071 \\
\hline hsa04622 & $\begin{array}{l}\text { RIG-I-like receptor } \\
\text { signaling pathway }\end{array}$ & 4 & 70 & 0.77 & 0.0075 \\
\hline hsa05218 & Melanoma & 4 & 72 & 0.76 & 0.0081 \\
\hline hsa05216 & Thyroid cancer & 3 & 37 & 0.92 & 0.0087 \\
\hline hsa05202 & $\begin{array}{c}\text { Transcriptional } \\
\text { misregulation in cancer }\end{array}$ & 6 & 169 & 0.56 & 0.0091 \\
\hline hsa04152 & AMPK signaling pathway & 5 & 120 & 0.63 & 0.0093 \\
\hline hsa04962 & $\begin{array}{l}\text { Vasopressin-regulated } \\
\text { water reabsorption }\end{array}$ & 3 & 44 & 0.85 & 0.0132 \\
\hline hsa05132 & Salmonella infection & 4 & 84 & 0.69 & 0.0132 \\
\hline hsa03015 & $\begin{array}{l}\text { mRNA surveillance } \\
\text { pathway }\end{array}$ & 4 & 89 & 0.67 & 0.0157 \\
\hline hsa04913 & Ovarian steroidogenesis & 3 & 49 & 0.8 & 0.0171 \\
\hline hsa05030 & Cocaine addiction & 3 & 49 & 0.8 & 0.0171 \\
\hline hsa03460 & Fanconi anemia pathway & 3 & 51 & 0.78 & 0.0187 \\
\hline hsa05134 & Legionellosis & 3 & 54 & 0.76 & 0.0215 \\
\hline hsa04137 & Mitophagy_animal & 3 & 63 & 0.69 & 0.0314 \\
\hline hsa04714 & Thermogenesis & 6 & 228 & 0.43 & 0.0314 \\
\hline hsa04927 & $\begin{array}{l}\text { Cortisol synthesis } \\
\text { and secretion }\end{array}$ & 3 & 63 & 0.69 & 0.0314 \\
\hline hsa04976 & Bile secretion & 3 & 71 & 0.64 & 0.0413 \\
\hline hsa04136 & Autophagy—other & 2 & 30 & 0.84 & 0.045 \\
\hline
\end{tabular}




\section{References}

1. Christiaansen, A.; Varga, S.M.; Spencer, J.V. Viral manipulation of the host immune response. Curr. Opin. Immunol. 2015, 36, 54-60. [CrossRef]

2. McLean, J.E.; Ruck, A.; Shirazian, A.; Pooyaei-Mehr, F.; Zakeri, Z.F. Viral manipulation of cell death. Curr. Pharm. Des. 2008, 14, 198-220. [CrossRef] [PubMed]

3. Garcia-Etxebarria, K.; Sistiaga-Poveda, M.; Jugo, B.M. Endogenous retroviruses in domestic animals. Curr. Genom. 2014, 15, 256-265. [CrossRef] [PubMed]

4. Xu, X.; Zhao, H.; Gong, Z.; Han, G.Z. Endogenous retroviruses of non-avian/mammalian vertebrates illuminate diversity and deep history of retroviruses. PLoS Pathog. 2018, 14, e1007072. [CrossRef]

5. Nelson, P.N.; Carnegie, P.R.; Martin, J.; Davari Ejtehadi, H.; Hooley, P.; Roden, D.; Rowland-Jones, S.; Warren, P.; Astley, J.; Murray, P.G. Demystified. Human endogenous retroviruses. Mol. Pathol. 2003, 56, 11-18. [CrossRef]

6. Mayer, J.; Meese, E. Human endogenous retroviruses in the primate lineage and their influence on host genomes. Cytogenet. Genome Res. 2005, 110, 448-456. [CrossRef]

7. Hohn, O.; Hanke, K.; Bannert, N. HERV-K(HML-2), the Best Preserved Family of HERVs: Endogenization, Expression, and Implications in Health and Disease. Front. Oncol. 2013, 3, 246. [CrossRef]

8. Downey, R.F.; Sullivan, F.J.; Wang-Johanning, F.; Ambs, S.; Giles, F.J.; Glynn, S.A. Human endogenous retrovirus K and cancer: Innocent bystander or tumorigenic accomplice? Int. J. Cancer 2015, 137, 1249-1257. [CrossRef]

9. Douville, R.; Liu, J.; Rothstein, J.; Nath, A. Identification of active loci of a human endogenous retrovirus in neurons of patients with amyotrophic lateral sclerosis. Ann. Neurol. 2011, 69, 141-151. [CrossRef]

10. Manghera, M.; Ferguson-Parry, J.; Douville, R.N. TDP-43 regulates endogenous retrovirus-K viral protein accumulation. Neurobiol. Dis. 2016, 94, 226-236. [CrossRef] [PubMed]

11. Manghera, M.; Ferguson-Parry, J.; Lin, R.; Douville, R.N. NF-kappaB and IRF1 Induce Endogenous Retrovirus K Expression via Interferon-Stimulated Response Elements in Its 5' Long Terminal Repeat. J. Virol. 2016, 90, 9338-9349. [CrossRef] [PubMed]

12. Arru, G.; Mameli, G.; Deiana, G.A.; Rassu, A.L.; Piredda, R.; Sechi, E.; Caggiu, E.; Bo, M.; Nako, E.; Urso, D.; et al. Humoral immunity response to human endogenous retroviruses $\mathrm{K} / \mathrm{W}$ differentiates between amyotrophic lateral sclerosis and other neurological diseases. Eur. J. Neurol. 2018, 25, e1076-e1084. [CrossRef] [PubMed]

13. Romer, C. Viruses and Endogenous Retroviruses as Roots for Neuroinflammation and Neurodegenerative Diseases. Front. Neurosci. 2021, 15, 648629. [CrossRef]

14. Greenig, M. HERVs, immunity, and autoimmunity: Understanding the connection. PeerJ 2019, 7, e6711. [CrossRef] [PubMed]

15. Vincendeau, M.; Gottesdorfer, I.; Schreml, J.M.; Wetie, A.G.; Mayer, J.; Greenwood, A.D.; Helfer, M.; Kramer, S.; Seifarth, W.; Hadian, K.; et al. Modulation of human endogenous retrovirus (HERV) transcription during persistent and de novo HIV-1 infection. Retrovirology 2015, 12, 27. [CrossRef]

16. Pilie, P.G.; Tang, C.; Mills, G.B.; Yap, T.A. State-of-the-art strategies for targeting the DNA damage response in cancer. Nat. Rev. Clin. Oncol. 2019, 16, 81-104. [CrossRef]

17. Penndorf, D.; Witte, O.W.; Kretz, A. DNA plasticity and damage in amyotrophic lateral sclerosis. Neural Regen. Res. 2018, 13, 173-180. [CrossRef]

18. Gao, F.B.; Almeida, S.; Lopez-Gonzalez, R. Dysregulated molecular pathways in amyotrophic lateral sclerosis-frontotemporal dementia spectrum disorder. EMBO J. 2017, 36, 2931-2950. [CrossRef]

19. Kessl, J.J.; Kutluay, S.B.; Townsend, D.; Rebensburg, S.; Slaughter, A.; Larue, R.C.; Shkriabai, N.; Bakouche, N.; Fuchs, J.R.; Bieniasz, P.D.; et al. HIV-1 Integrase Binds the Viral RNA Genome and Is Essential during Virion Morphogenesis. Cell 2016, 166, 1257-1268.e1212. [CrossRef]

20. Lesbats, P.; Engelman, A.N.; Cherepanov, P. Retroviral DNA Integration. Chem. Rev. 2016, 116, 12730-12757. [CrossRef]

21. Daniel, R.; Kao, G.; Taganov, K.; Greger, J.G.; Favorova, O.; Merkel, G.; Yen, T.J.; Katz, R.A.; Skalka, A.M. Evidence that the retroviral DNA integration process triggers an ATR-dependent DNA damage response. Proc. Natl. Acad. Sci. USA 2003, 100, 4778-4783. [CrossRef] [PubMed]

22. Skalka, A.M.; Katz, R.A. Retroviral DNA integration and the DNA damage response. Cell Death Differ. 2005, 12 (Suppl. S1), 971-978. [CrossRef] [PubMed]

23. Bray, S.; Turnbull, M.; Hebert, S.; Douville, R.N. Insight into the ERVK Integrase-Propensity for DNA Damage. Front. Microbiol. 2016, 7, 1941. [CrossRef]

24. Kitamura, Y.; Ayukawa, T.; Ishikawa, T.; Kanda, T.; Yoshiike, K. Human endogenous retrovirus K10 encodes a functional integrase. J. Virol. 1996, 70, 3302-3306. [CrossRef]

25. Van Maele, B.; Busschots, K.; Vandekerckhove, L.; Christ, F.; Debyser, Z. Cellular co-factors of HIV-1 integration. Trends Biochem. Sci. 2006, 31, 98-105. [CrossRef] [PubMed]

26. Christ, F.; Debyser, Z. The LEDGF/p75 integrase interaction, a novel target for anti-HIV therapy. Virology 2013, 435, 102-109. [CrossRef]

27. Studamire, B.; Goff, S.P. Interactions of host proteins with the murine leukemia virus integrase. Viruses 2010, 2, 1110-1145. [CrossRef]

28. Jayappa, K.D.; Ao, Z.; Wang, X.; Mouland, A.J.; Shekhar, S.; Yang, X.; Yao, X. Human immunodeficiency virus type 1 employs the cellular dynein light chain 1 protein for reverse transcription through interaction with its integrase protein. J. Virol. 2015, 89, 3497-3511. [CrossRef]

29. Ryan, E.L.; Hollingworth, R.; Grand, R.J. Activation of the DNA Damage Response by RNA Viruses. Biomolecules 2016, 6, 2. [CrossRef] 
30. Suzuki, Y.; Craigie, R. The road to chromatin-Nuclear entry of retroviruses. Nat. Rev. Microbiol. 2007, 5, 187-196. [CrossRef]

31. Suzuki, Y.; Chew, M.L. Role of host-encoded proteins in restriction of retroviral integration. Front. Microbiol. 2012, 3, 227. [CrossRef]

32. Daniel, R.; Greger, J.G.; Katz, R.A.; Taganov, K.D.; Wu, X.; Kappes, J.C.; Skalka, A.M. Evidence that stable retroviral transduction and cell survival following DNA integration depend on components of the nonhomologous end joining repair pathway. J. Virol. 2004, 78, 8573-8581. [CrossRef]

33. Turlure, F.; Devroe, E.; Silver, P.A.; Engelman, A. Human cell proteins and human immunodeficiency virus DNA integration. Front. Biosci. 2004, 9, 3187-3208. [CrossRef]

34. Cooper, A.; Garcia, M.; Petrovas, C.; Yamamoto, T.; Koup, R.A.; Nabel, G.J. HIV-1 causes CD4 cell death through DNA-dependent protein kinase during viral integration. Nature 2013, 498, 376-379. [CrossRef] [PubMed]

35. Hanahan, D.; Weinberg, R.A. Hallmarks of cancer: The next generation. Cell 2011, 144, 646-674. [CrossRef] [PubMed]

36. Mourad, R.; Ginalski, K.; Legube, G.; Cuvier, O. Predicting double-strand DNA breaks using epigenome marks or DNA at kilobase resolution. Genome Biol. 2018, 19, 34. [CrossRef]

37. Stetson, D.B.; Ko, J.S.; Heidmann, T.; Medzhitov, R. Trex1 prevents cell-intrinsic initiation of autoimmunity. Cell 2008, 134, 587-598. [CrossRef] [PubMed]

38. Zhang, J.; Scadden, D.T.; Crumpacker, C.S. Primitive hematopoietic cells resist HIV-1 infection via p21. J. Clin. Investig. 2007, 117, 473-481. [CrossRef]

39. Ran, X.; Ao, Z.; Olukitibi, T.; Yao, X. Characterization of the Role of Host Cellular Factor Histone Deacetylase 10 during HIV-1 Replication. Viruses 2019, 12, 28. [CrossRef]

40. Ali, H.; Mano, M.; Braga, L.; Naseem, A.; Marini, B.; Vu, D.M.; Collesi, C.; Meroni, G.; Lusic, M.; Giacca, M. Cellular TRIM33 restrains HIV-1 infection by targeting viral integrase for proteasomal degradation. Nat. Commun. 2019, 10, 926. [CrossRef] [PubMed]

41. Mulder, L.C.; Chakrabarti, L.A.; Muesing, M.A. Interaction of HIV-1 integrase with DNA repair protein hRad18. J. Biol. Chem. 2002, 277, 27489-27493. [CrossRef] [PubMed]

42. Van Maele, B.; Debyser, Z. HIV-1 integration: An interplay between HIV-1 integrase, cellular and viral proteins. AIDS Rev. 2005, 7, 26-43. [PubMed]

43. Anisenko, A.N.; Knyazhanskaya, E.S.; Zalevsky, A.O.; Agapkina, J.Y.; Sizov, A.I.; Zatsepin, T.S.; Gottikh, M.B. Characterization of HIV-1 integrase interaction with human Ku70 protein and initial implications for drug targeting. Sci. Rep. 2017, 7, 5649. [CrossRef]

44. BLAST. Available online: https:/ / www.ncbi.nlm.nih.gov/BLAST/ (accessed on 12 July 2021).

45. Rosindell, J.; Harmon, L.J. OneZoom: A fractal explorer for the tree of life. PLoS Biol. 2012, 10, e1001406. [CrossRef] [PubMed]

46. Kearse, M.; Moir, R.; Wilson, A.; Stones-Havas, S.; Cheung, M.; Sturrock, S.; Buxton, S.; Cooper, A.; Markowitz, S.; Duran, C.; et al. Geneious Basic: An integrated and extendable desktop software platform for the organization and analysis of sequence data. Bioinformatics 2012, 28, 1647-1649. [CrossRef] [PubMed]

47. Lu, S.; Wang, J.; Chitsaz, F.; Derbyshire, M.K.; Geer, R.C.; Gonzales, N.R.; Gwadz, M.; Hurwitz, D.I.; Marchler, G.H.; Song, J.S.; et al. CDD/SPARCLE: The conserved domain database in 2020. Nucleic Acids Res. 2020, 48, D265-D268. [CrossRef] [PubMed]

48. Kumar, M.; Gouw, M.; Michael, S.; Sámano-Sánchez, H.; Pancsa, R.; Glavina, J.; Diakogianni, A.; Valverde, J.A.; Bukirova, D.; Čalyševa, J.; et al. ELM-the eukaryotic linear motif resource in 2020. Nucleic Acids Res. 2020, 48, D296-D306. [CrossRef]

49. Lee, Y.M.; Liou, Y.C. Gears-In-Motion: The Interplay of WW and PPIase Domains in Pin1. Front. Oncol. 2018, 8, 469. [CrossRef]

50. Ramos, F.; Villoria, M.T.; Alonso-Rodriguez, E.; Clemente-Blanco, A. Role of protein phosphatases PP1, PP2A, PP4 and Cdc14 in the DNA damage response. Cell Stress 2019, 3, 70-85. [CrossRef]

51. Knippschild, U.; Kruger, M.; Richter, J.; Xu, P.; Garcia-Reyes, B.; Peifer, C.; Halekotte, J.; Bakulev, V.; Bischof, J. The CK1 Family: Contribution to Cellular Stress Response and Its Role in Carcinogenesis. Front. Oncol. 2014, 4, 96. [CrossRef]

52. Fry, A.M.; O’Regan, L.; Sabir, S.R.; Bayliss, R. Cell cycle regulation by the NEK family of protein kinases. J. Cell Sci. 2012, 125, 4423-4433. [CrossRef]

53. Kumar, S.; Sharma, G.; Chakraborty, C.; Sharma, A.R.; Kim, J. Regulatory functional territory of PLK-1 and their substrates beyond mitosis. Oncotarget 2017, 8, 37942-37962. [CrossRef] [PubMed]

54. Reinhardt, H.C.; Yaffe, M.B. Phospho-Ser/Thr-binding domains: Navigating the cell cycle and DNA damage response. Nat. Rev. Mol. Cell Biol. 2013, 14, 563-580. [CrossRef]

55. Chang, Z.; Wang, Y.; Zhou, X.; Long, J.E. STAT3 roles in viral infection: Antiviral or proviral? Future Virol. 2018, 13, 557-574. [CrossRef] [PubMed]

56. Rani, A.; Murphy, J.J. STAT5 in Cancer and Immunity. J. Interferon Cytokine Res. 2016, 36, 226-237. [CrossRef]

57. Mahajan, K.; Mahajan, N.P. Cross talk of tyrosine kinases with the DNA damage signaling pathways. Nucleic Acids Res. 2015, 43, 10588-10601. [CrossRef]

58. Teyra, J.; Huang, H.; Jain, S.; Guan, X.; Dong, A.; Liu, Y.; Tempel, W.; Min, J.; Tong, Y.; Kim, P.M.; et al. Comprehensive Analysis of the Human SH3 Domain Family Reveals a Wide Variety of Non-canonical Specificities. Structure 2017, 25, 1598-1610.e3. [CrossRef] [PubMed]

59. Lalaoui, N.; Vaux, D.L. Recent advances in understanding inhibitor of apoptosis proteins. F1000Research 2018, 7. [CrossRef]

60. Liu, H.; Li, L.; Voss, C.; Wang, F.; Liu, J.; Li, S.S. A Comprehensive Immunoreceptor Phosphotyrosine-based Signaling Network Revealed by Reciprocal Protein-Peptide Array Screening. Mol. Cell Proteom. 2015, 14, 1846-1858. [CrossRef] [PubMed]

61. Beurel, E.; Grieco, S.F.; Jope, R.S. Glycogen synthase kinase-3 (GSK3): Regulation, actions, and diseases. Pharmacol. Ther. 2015, 148, 114-131. [CrossRef] 
62. Canovas, B.; Nebreda, A.R. Diversity and versatility of p38 kinase signalling in health and disease. Nat. Rev. Mol. Cell Biol. 2021, 22, 346-366. [CrossRef]

63. Covill-Cooke, C.; Toncheva, V.S.; Kittler, J.T. Regulation of peroxisomal trafficking and distribution. Cell. Mol. Life Sci. 2021, 78, 1929-1941. [CrossRef]

64. Kumar, P.; Wittmann, T. + TIPs: SxIPping along microtubule ends. Trends Cell Biol. 2012, 22, 418-428. [CrossRef]

65. Park, S.Y.; Guo, X. Adaptor protein complexes and intracellular transport. Biosci. Rep. 2014, 34. [CrossRef]

66. Egea, P.F. Crossing the Vacuolar Rubicon: Structural Insights into Effector Protein Trafficking in Apicomplexan Parasites. Microorganisms 2020, 8, 865. [CrossRef] [PubMed]

67. Matic, I.; Schimmel, J.; Hendriks, I.A.; van Santen, M.A.; van de Rijke, F.; van Dam, H.; Gnad, F.; Mann, M.; Vertegaal, A.C. Sitespecific identification of SUMO-2 targets in cells reveals an inverted SUMOylation motif and a hydrophobic cluster SUMOylation motif. Mol. Cell 2010, 39, 641-652. [CrossRef]

68. Zamborlini, A.; Coiffic, A.; Beauclair, G.; Delelis, O.; Paris, J.; Koh, Y.; Magne, F.; Giron, M.L.; Tobaly-Tapiero, J.; Deprez, E.; et al. Impairment of human immunodeficiency virus type-1 integrase SUMOylation correlates with an early replication defect. J. Biol. Chem. 2011, 286, 21013-21022. [CrossRef] [PubMed]

69. Zhao, X. SUMO-Mediated Regulation of Nuclear Functions and Signaling Processes. Mol. Cell 2018, 71, 409-418. [CrossRef] [PubMed]

70. Quek, H.; Lim, Y.C.; Lavin, M.F.; Roberts, T.L. PIKKing a way to regulate inflammation. Immunol. Cell Biol. 2018, 96, 8-20. [CrossRef]

71. Penalosa-Ruiz, G.; Bousgouni, V.; Gerlach, J.P.; Waarlo, S.; van de Ven, J.V.; Veenstra, T.E.; Silva, J.C.R.; van Heeringen, S.J.; Bakal, C.; Mulder, K.W.; et al. WDR5, BRCA1, and BARD1 Co-regulate the DNA Damage Response and Modulate the Mesenchymal-to-Epithelial Transition during Early Reprogramming. Stem Cell Rep. 2019, 12, 743-756. [CrossRef] [PubMed]

72. Wheatley, S.P.; Altieri, D.C. Survivin at a glance. J. Cell Sci. 2019, 132. [CrossRef] [PubMed]

73. Fang, Y.; Zhang, X. Targeting NEK2 as a promising therapeutic approach for cancer treatment. Cell Cycle 2016, 15, 895-907. [CrossRef]

74. De Carcer, G. The Mitotic Cancer Target Polo-Like Kinase 1: Oncogene or Tumor Suppressor? Genes 2019, 10, 208. [CrossRef] [PubMed]

75. Van Grevenynghe, J.; Cubas, R.A.; DaFonseca, S.; Metcalf, T.; Tremblay, C.L.; Trautmann, L.; Sekaly, R.P.; Schatzle, J.; Haddad, E.K. Foxo3a: An integrator of immune dysfunction during HIV infection. Cytokine Growth Factor Rev. 2012, 23, 215-221. [CrossRef]

76. Aloni-Grinstein, R.; Charni-Natan, M.; Solomon, H.; Rotter, V. p53 and the Viral Connection: Back into the Future (double dagger). Cancers 2018, 10, 178. [CrossRef]

77. Ho, J.; Moyes, D.L.; Tavassoli, M.; Naglik, J.R. The Role of ErbB Receptors in Infection. Trends Microbiol. 2017, 25, 942-952. [CrossRef]

78. Khanizadeh, S.; Hasanvand, B.; Esmaeil Lashgarian, H.; Almasian, M.; Goudarzi, G. Interaction of viral oncogenic proteins with the Wnt signaling pathway. Iran. J. Basic Med. Sci. 2018, 21, 651-659. [CrossRef]

79. De Martini, W.; Rahman, R.; Ojegba, E.; Jungwirth, E.; Macias, J.; Ackerly, F.; Fowler, M.; Cottrell, J.; Chu, T.; Chang, S.L. Kinases: Understanding Their Role in HIV Infection. World J. AIDS 2019, 9, 142-160. [CrossRef]

80. Medders, K.E.; Kaul, M. Mitogen-activated protein kinase p38 in HIV infection and associated brain injury. J. Neuroimmune Pharmacol. 2011, 6, 202-215. [CrossRef]

81. Saez-Cirion, A.; Manel, N. Immune Responses to Retroviruses. Annu. Rev. Immunol. 2018, 36, 193-220. [CrossRef] [PubMed]

82. Shi, J.H.; Sun, S.C. Tumor Necrosis Factor Receptor-Associated Factor Regulation of Nuclear Factor kappaB and MitogenActivated Protein Kinase Pathways. Front. Immunol. 2018, 9, 1849. [CrossRef] [PubMed]

83. Nehlig, A.; Molina, A.; Rodrigues-Ferreira, S.; Honore, S.; Nahmias, C. Regulation of end-binding protein EB1 in the control of microtubule dynamics. Cell. Mol. Life Sci. 2017, 74, 2381-2393. [CrossRef] [PubMed]

84. Cao, H.; Orth, J.D.; Chen, J.; Weller, S.G.; Heuser, J.E.; McNiven, M.A. Cortactin is a component of clathrin-coated pits and participates in receptor-mediated endocytosis. Mol. Cell. Biol. 2003, 23, 2162-2170. [CrossRef]

85. Zare, M.; Mostafaei, S.; Ahmadi, A.; Azimzadeh Jamalkandi, S.; Abedini, A.; Esfahani-Monfared, Z.; Dorostkar, R.; Saadati, M. Human endogenous retrovirus env genes: Potential blood biomarkers in lung cancer. Microb. Pathog. 2018, 115, 189-193. [CrossRef]

86. Bergallo, M.; Montanari, P.; Mareschi, K.; Merlino, C.; Berger, M.; Bini, I.; Dapra, V.; Galliano, I.; Fagioli, F. Expression of the pol gene of human endogenous retroviruses HERV-K and -W in leukemia patients. Arch. Virol 2017, 162, 3639-3644. [CrossRef]

87. Ma, W.; Hong, Z.; Liu, H.; Chen, X.; Ding, L.; Liu, Z.; Zhou, F.; Yuan, Y. Human Endogenous Retroviruses-K (HML-2) Expression Is Correlated with Prognosis and Progress of Hepatocellular Carcinoma. BioMed Res. Int. 2016, 2016, 8201642. [CrossRef]

88. Yuan, Z.; Yang, Y.; Zhang, N.; Soto, C.; Jiang, X.; An, Z.; Zheng, W.J. Human Endogenous Retroviruses in Glioblastoma Multiforme. Microorganisms 2021, 9, 764. [CrossRef] [PubMed]

89. Dembny, P.; Newman, A.G.; Singh, M.; Hinz, M.; Szczepek, M.; Kruger, C.; Adalbert, R.; Dzaye, O.; Trimbuch, T.; Wallach, T.; et al. Human endogenous retrovirus HERV-K(HML-2) RNA causes neurodegeneration through Toll-like receptors. JCI Insight 2020, 5. [CrossRef]

90. Jeong, B.H.; Lee, Y.J.; Carp, R.I.; Kim, Y.S. The prevalence of human endogenous retroviruses in cerebrospinal fluids from patients with sporadic Creutzfeldt-Jakob disease. J. Clin. Virol. 2010, 47, 136-142. [CrossRef]

91. Tovo, P.A.; Rabbone, I.; Tinti, D.; Galliano, I.; Trada, M.; Dapra, V.; Cerutti, F.; Bergallo, M. Enhanced expression of human endogenous retroviruses in new-onset type 1 diabetes: Potential pathogenetic and therapeutic implications. Autoimmunity 2020, 53, 283-288. [CrossRef] [PubMed]

92. Mason, M.J.; Speake, C.; Gersuk, V.H.; Nguyen, Q.A.; O’Brien, K.K.; Odegard, J.M.; Buckner, J.H.; Greenbaum, C.J.; Chaussabel, D.; Nepom, G.T. Low HERV-K(C4) copy number is associated with type 1 diabetes. Diabetes 2014, 63, 1789-1795. [CrossRef] [PubMed] 
93. Dickerson, F.; Rubalcaba, E.; Viscidi, R.; Yang, S.; Stallings, C.; Sullens, A.; Origoni, A.; Leister, F.; Yolken, R. Polymorphisms in human endogenous retrovirus K-18 and risk of type 2 diabetes in individuals with schizophrenia. Schizophr. Res. 2008, 104, 121-126. [CrossRef] [PubMed]

94. Cinek, O.; Kramna, L.; Odeh, R.; Alassaf, A.; Ibekwe, M.A.U.; Ahmadov, G.; Elmahi, B.M.E.; Mekki, H.; Lebl, J.; Abdullah, M.A. Eukaryotic viruses in the fecal virome at the onset of type 1 diabetes: A study from four geographically distant African and Asian countries. Pediatr. Diabetes 2021, 22, 558-566. [CrossRef] [PubMed]

95. Piekna-Przybylska, D.; Sharma, G.; Maggirwar, S.B.; Bambara, R.A. Deficiency in DNA damage response, a new characteristic of cells infected with latent HIV-1. Cell Cycle 2017, 16, 968-978. [CrossRef]

96. Li, D.; Lopez, A.; Sandoval, C.; Nichols Doyle, R.; Fregoso, O.I. HIV Vpr Modulates the Host DNA Damage Response at Two Independent Steps to Damage DNA and Repress Double-Strand DNA Break Repair. mBio 2020, 11. [CrossRef]

97. Zhi, H.; Guo, X.; Ho, Y.K.; Pasupala, N.; Engstrom, H.A.A.; Semmes, O.J.; Giam, C.Z. RNF8 Dysregulation and Down-regulation During HTLV-1 Infection Promote Genomic Instability in Adult T-Cell Leukemia. PLoS Pathog. 2020, 16, e1008618. [CrossRef]

98. Luftig, M.A. Viruses and the DNA Damage Response: Activation and Antagonism. Annu. Rev. Virol. 2014, 1, 605-625. [CrossRef]

99. Hristova, D.B.; Lauer, K.B.; Ferguson, B.J. Viral interactions with non-homologous end-joining: A game of hide-and-seek. J. Gen. Virol. 2020, 101, 1133-1144. [CrossRef]

100. Mohammad, D.H.; Yaffe, M.B. 14-3-3 proteins, FHA domains and BRCT domains in the DNA damage response. DNA Repair 2009, 8, 1009-1017. [CrossRef]

101. Pancholi, N.J.; Price, A.M.; Weitzman, M.D. Take your PIKK: Tumour viruses and DNA damage response pathways. Philos. Trans. R. Soc. Lond. B Biol. Sci. 2017, 372. [CrossRef]

102. Zimmerman, E.S.; Chen, J.; Andersen, J.L.; Ardon, O.; Dehart, J.L.; Blackett, J.; Choudhary, S.K.; Camerini, D.; Nghiem, P.; Planelles, V. Human immunodeficiency virus type 1 Vpr-mediated G2 arrest requires Rad17 and Hus1 and induces nuclear BRCA1 and gamma-H2AX focus formation. Mol. Cell. Biol. 2004, 24, 9286-9294. [CrossRef]

103. Shukrun, M.; Jabareen, A.; Abou-Kandil, A.; Chamias, R.; Aboud, M.; Huleihel, M. HTLV-1 Tax oncoprotein inhibits the estrogeninduced-ER alpha-Mediated BRCA1 expression by interaction with CBP/p300 cofactors. PLoS ONE 2014, 9, e89390. [CrossRef]

104. Nathan, K.G.; Lal, S.K. The Multifarious Role of 14-3-3 Family of Proteins in Viral Replication. Viruses 2020, $12,436$. [CrossRef] [PubMed]

105. Wu, Q.; Jubb, H.; Blundell, T.L. Phosphopeptide interactions with BRCA1 BRCT domains: More than just a motif. Prog. Biophys. Mol. Biol. 2015, 117, 143-148. [CrossRef] [PubMed]

106. Clapperton, J.A.; Manke, I.A.; Lowery, D.M.; Ho, T.; Haire, L.F.; Yaffe, M.B.; Smerdon, S.J. Structure and mechanism of BRCA1 BRCT domain recognition of phosphorylated BACH1 with implications for cancer. Nat. Struct. Mol. Biol. 2004, 11, 512-518. [CrossRef] [PubMed]

107. Fan, X.; Cui, L.; Zeng, Y.; Song, W.; Gaur, U.; Yang, M. 14-3-3 Proteins Are on the Crossroads of Cancer, Aging, and Age-Related Neurodegenerative Disease. Int. J. Mol. Sci. 2019, 20, 3518. [CrossRef]

108. Morales, D.; Skoulakis, E.C.; Acevedo, S.F. 14-3-3s are potential biomarkers for HIV-related neurodegeneration. J. Neurovirol. 2012, 18, 341-353. [CrossRef] [PubMed]

109. Roskoski, R., Jr. RAF protein-serine/threonine kinases: Structure and regulation. Biochem. Biophys. Res. Commun. 2010, 399, 313-317. [CrossRef]

110. Tang, J.; Wang, J.Y.; Parker, L.L. Detection of early Abl kinase activation after ionizing radiation by using a peptide biosensor. ChemBioChem Eur. J. Chem. Biol. 2012, 13, 665-673. [CrossRef]

111. McCarthy, S.D.S.; Leontyev, D.; Nicoletti, P.; Binnington, B.; Kozlowski, H.N.; Ostrowski, M.; Cochrane, A.; Branch, D.R.; Wong, R.W. Targeting ABL1 or ARG Tyrosine Kinases to Restrict HIV-1 Infection in Primary CD4+ T-Cells or in Humanized NSG Mice. J. Acquir. Immune Defic. Syndr. 2019, 82, 407-415. [CrossRef]

112. Kodama, D.; Tanaka, M.; Matsuzaki, T.; Izumo, K.; Nakano, N.; Matsuura, E.; Saito, M.; Nagai, M.; Horiuchi, M.; Utsunomiya, A.; et al. Inhibition of ABL1 tyrosine kinase reduces HTLV-1 proviral loads in peripheral blood mononuclear cells from patients with HTLV-1-associated myelopathy/tropical spastic paraparesis. PLoS Negl. Trop. Dis. 2020, 14, e0008361. [CrossRef]

113. Baskaran, R.; Escobar, S.R.; Wang, J.Y. Nuclear c-Abl is a COOH-terminal repeated domain (CTD)-tyrosine (CTD)-tyrosine kinase-specific for the mammalian RNA polymerase II: Possible role in transcription elongation. Cell Growth Differ. 1999, 10, 387-396. [PubMed]

114. Schlatterer, S.D.; Acker, C.M.; Davies, P. c-Abl in neurodegenerative disease. J. Mol. Neurosci. 2011, 45, 445-452. [CrossRef] [PubMed]

115. Kim, B.W.; Jeong, Y.E.; Wong, M.; Martin, L.J. DNA damage accumulates and responses are engaged in human ALS brain and spinal motor neurons and DNA repair is activatable in iPSC-derived motor neurons with SOD1 mutations. Acta Neuropathol. Commun. 2020, 8, 7. [CrossRef] [PubMed]

116. Wang, W.; Mani, A.M.; Wu, Z.H. DNA damage-induced nuclear factor-kappa B activation and its roles in cancer progression. J. Cancer Metastasis Treat. 2017, 3, 45-59. [CrossRef]

117. Zuo, S.; Xue, Y.; Tang, S.; Yao, J.; Du, R.; Yang, P.; Chen, X. 14-3-3 epsilon dynamically interacts with key components of mitogen-activated protein kinase signal module for selective modulation of the TNF-alpha-induced time course-dependent NF-kappaB activity. J. Proteome Res. 2010, 9, 3465-3478. [CrossRef] 
118. Pennington, K.L.; Chan, T.Y.; Torres, M.P.; Andersen, J.L. The dynamic and stress-adaptive signaling hub of 14-3-3: Emerging mechanisms of regulation and context-dependent protein-protein interactions. Oncogene 2018, 37, 5587-5604. [CrossRef]

119. Saha, R.N.; Jana, M.; Pahan, K. MAPK p38 regulates transcriptional activity of NF-kappaB in primary human astrocytes via acetylation of p65. J. Immunol. 2007, 179, 7101-7109. [CrossRef]

120. Zheng, Y.; Ao, Z.; Wang, B.; Jayappa, K.D.; Yao, X. Host protein Ku70 binds and protects HIV-1 integrase from proteasomal degradation and is required for HIV replication. J. Biol. Chem. 2011, 286, 17722-17735. [CrossRef] [PubMed]

121. Llano, M.; Delgado, S.; Vanegas, M.; Poeschla, E.M. Lens epithelium-derived growth factor/p75 prevents proteasomal degradation of HIV-1 integrase. J. Biol. Chem. 2004, 279, 55570-55577. [CrossRef]

122. Manganaro, L.; Lusic, M.; Gutierrez, M.I.; Cereseto, A.; Del Sal, G.; Giacca, M. Concerted action of cellular JNK and Pin1 restricts HIV-1 genome integration to activated CD4+ T lymphocytes. Nat. Med. 2010, 16, 329-333. [CrossRef]

123. Quy, V.C.; Carnevale, V.; Manganaro, L.; Lusic, M.; Rossetti, G.; Leone, V.; Fenollar-Ferrer, C.; Raugei, S.; Del Sal, G.; Giacca, M.; et al. HIV-1 integrase binding to its cellular partners: A perspective from computational biology. Curr. Pharm. Des. 2014, 20, 3412-3421. [CrossRef] [PubMed]

124. Kojima, Y.; Ryo, A. Pinning down viral proteins: A new prototype for virus-host cell interaction. Front. Microbiol. 2010, 1, 107. [CrossRef] [PubMed]

125. Nieto-Torres, J.L.; Leidal, A.M.; Debnath, J.; Hansen, M. Beyond Autophagy: The Expanding Roles of ATG8 Proteins. Trends Biochem. Sci. 2021. [CrossRef] [PubMed]

126. Leymarie, O.; Lepont, L.; Berlioz-Torrent, C. Canonical and Non-Canonical Autophagy in HIV-1 Replication Cycle. Viruses 2017, 9, 270. [CrossRef] [PubMed]

127. Vicencio, E.; Beltran, S.; Labrador, L.; Manque, P.; Nassif, M.; Woehlbier, U. Implications of Selective Autophagy Dysfunction for ALS Pathology. Cells 2020, 9, 381. [CrossRef]

128. Watanabe, Y.; Taguchi, K.; Tanaka, M. Ubiquitin, Autophagy and Neurodegenerative Diseases. Cells 2020, 9, 2022. [CrossRef]

129. Negrini, S.; Gorgoulis, V.G.; Halazonetis, T.D. Genomic instability-an evolving hallmark of cancer. Nat. Rev. Mol. Cell Biol. 2010, 11, 220-228. [CrossRef]

130. Sun, Y.; Curle, A.J.; Haider, A.M.; Balmus, G. The role of DNA damage response in amyotrophic lateral sclerosis. Essays Biochem. 2020, 64, 847-861. [CrossRef]

131. Hou, Y.; Song, H.; Croteau, D.L.; Akbari, M.; Bohr, V.A. Genome instability in Alzheimer disease. Mech. Ageing Dev. 2017, 161, 83-94. [CrossRef]

132. Madabhushi, R.; Pan, L.; Tsai, L.H. DNA damage and its links to neurodegeneration. Neuron 2014, 83, 266-282. [CrossRef]

133. Malaspina, A.; Kaushik, N.; de Belleroche, J. A 14-3-3 mRNA is up-regulated in amyotrophic lateral sclerosis spinal cord. J. Neurochem. 2000, 75, 2511-2520. [CrossRef]

134. Hermeking, H. The 14-3-3 cancer connection. Nat. Rev. Cancer 2003, 3, 931-943. [CrossRef] [PubMed]

135. Martin, L.J. p53 is abnormally elevated and active in the CNS of patients with amyotrophic lateral sclerosis. Neurobiol. Dis. 2000, 7, 613-622. [CrossRef] [PubMed]

136. Ozaki, T.; Nakagawara, A. Role of p53 in Cell Death and Human Cancers. Cancers 2011, 3, 994-1013. [CrossRef] [PubMed]

137. Koul, H.K.; Pal, M.; Koul, S. Role of p38 MAP Kinase Signal Transduction in Solid Tumors. Genes Cancer 2013, 4, 342-359. [CrossRef]

138. Guo, W.; Vandoorne, T.; Steyaert, J.; Staats, K.A.; Van Den Bosch, L. The multifaceted role of kinases in amyotrophic lateral sclerosis: Genetic, pathological and therapeutic implications. Brain 2020, 143, 1651-1673. [CrossRef] [PubMed]

139. Jiang, X.; Guan, Y.; Zhao, Z.; Meng, F.; Wang, X.; Gao, X.; Liu, J.; Chen, Y.; Zhou, F.; Zhou, S.; et al. Potential Roles of the WNT Signaling Pathway in Amyotrophic Lateral Sclerosis. Cells 2021, 10, 839. [CrossRef]

140. Menck, K.; Heinrichs, S.; Baden, C.; Bleckmann, A. The WNT/ROR Pathway in Cancer: From Signaling to Therapeutic Intervention. Cells 2021, 10, 142. [CrossRef]

141. Manigrasso, M.B.; Juranek, J.; Ramasamy, R.; Schmidt, A.M. Unlocking the biology of RAGE in diabetic microvascular complications. Trends Endocrinol. Metab. 2014, 25, 15-22. [CrossRef] [PubMed]

142. Kumar, V.; Fleming, T.; Terjung, S.; Gorzelanny, C.; Gebhardt, C.; Agrawal, R.; Mall, M.A.; Ranzinger, J.; Zeier, M.; Madhusudhan, T.; et al. Homeostatic nuclear RAGE-ATM interaction is essential for efficient DNA repair. Nucleic Acids Res. 2017, 45, 10595-10613. [CrossRef] [PubMed]

143. Abe, R.; Yamagishi, S. AGE-RAGE system and carcinogenesis. Curr. Pharm. Des. 2008, 14, 940-945. [CrossRef]

144. Derk, J.; MacLean, M.; Juranek, J.; Schmidt, A.M. The Receptor for Advanced Glycation Endproducts (RAGE) and Mediation of Inflammatory Neurodegeneration. J. Alzheimers Dis. Parkinsonism 2018, 8. [CrossRef]

145. Shaposhnikov, M.; Proshkina, E.; Shilova, L.; Zhavoronkov, A.; Moskalev, A. Lifespan and Stress Resistance in Drosophila with Overexpressed DNA Repair Genes. Sci. Rep. 2015, 5, 15299. [CrossRef]

146. Garinis, G.A.; van der Horst, G.T.; Vijg, J.; Hoeijmakers, J.H. DNA damage and ageing: New-age ideas for an age-old problem. Nat. Cell Biol. 2008, 10, 1241-1247. [CrossRef] [PubMed]

147. Engelman, A.N. Multifaceted HIV integrase functionalities and therapeutic strategies for their inhibition. J. Biol. Chem. 2019, 294, 15137-15157. [CrossRef]

148. Cherepanov, P. LEDGF/p75 interacts with divergent lentiviral integrases and modulates their enzymatic activity in vitro. Nucleic Acids Res. 2007, 35, 113-124. [CrossRef] [PubMed] 
149. Anisenko, A.; Kan, M.; Shadrina, O.; Brattseva, A.; Gottikh, M. Phosphorylation Targets of DNA-PK and Their Role in HIV-1 Replication. Cells 2020, 9, 1907. [CrossRef]

150. Santos da Silva, E.; Shanmugapriya, S.; Malikov, V.; Gu, F.; Delaney, M.K.; Naghavi, M.H. HIV-1 capsids mimic a microtubule regulator to coordinate early stages of infection. EMBO J. 2020, 39, e104870. [CrossRef]

151. De Oliveira, D.S.; Rosa, M.T.; Vieira, C.; Loreto, E.L.S. Oxidative and radiation stress induces transposable element transcription in Drosophila melanogaster. J. Evol. Biol. 2021, 34, 628-638. [CrossRef]

152. Salces-Ortiz, J.; Vargas-Chavez, C.; Guio, L.; Rech, G.E.; Gonzalez, J. Transposable elements contribute to the genomic response to insecticides in Drosophila melanogaster. Philos. Trans. R. Soc. Lond. B Biol. Sci. 2020, 375, 20190341. [CrossRef] 